\title{
Effects of glycosylation and D-amino acid substitution on the antitumor and antibacterial activities of bee venom peptide HYL
}

Ming-hao Wu, ${ }^{a, b} \mathrm{Su} A i,{ }^{a, b}$ Qing Chen, ${ }^{a, b}$ Xiang-yan Chen, ${ }^{a, b}$ Hong-jin Li, ${ }^{a}$ Yu-lei Li, ${ }^{a}$ Xia Zhao, a,b*

a. Key Laboratory of Marine Drugs, Ministry of Education, School of Medicine and Pharmacy, Ocean University of China, Qingdao 266003, China

b. Laboratory for Marine Drugs and Bioproducts of Qingdao National Laboratory for Marine Science and Technology, Qingdao 266237, China

${ }^{*}$ Corresponding author at: Key Laboratory of Marine Drugs, Ministry of Education, School of Medicine and Pharmacy, Ocean University of China, Qingdao 266003, China.Tel \& Fax: 86-532-82031560. E-mail address: 1184748799@qq.com \& zhaoxia@ouc.edu.cn (X.Zhao). 


\section{Table of contents}

Table S1: MS data for glycoamino acids

Table S2: MS data for HYL and its analogues

Table S3: The antitumor activity of peptides

Table S4: The antimicrobial and hemolytic activity of peptides

Table S5: The $\alpha$-helicity (\%) of peptides

Scheme S1. Schematic diagram of HYL synthesis

Figure S1. Synthesis of the stapled peptide HYL-14

Figure S2: Synthesis and structures of glycoamino acids

Figure S3. Circular dichroism spectroscopy of peptides

Figure S4. Analytical HPLC trace for peptide proteolytic stability

Spectrum 
Table S1: MS data for glycoamino acids

\begin{tabular}{lccc}
\hline \multicolumn{1}{c}{ Amino acid } & MS(Calcd) & MS(found) & Yield \\
\hline Fmoc-Ser[Glc $\left.\left(\mathrm{AC}_{3}\right) \mathrm{NAc} \beta\right]-\mathrm{OH}$ & 656.22 & 656.30 & $22.53 \%$ \\
Fmoc-Ser[Glc $\left.\left(\mathrm{AC}_{4}\right) \beta\right]-\mathrm{OH}$ & 657.21 & 657.30 & $23.45 \%$ \\
Fmoc-Ser[Gal $\left.\left(\mathrm{AC}_{4}\right) \beta\right]-\mathrm{OH}$ & 657.21 & 657.20 & $21.38 \%$ \\
Fmoc-Ser[Fuc $\left.\left(\mathrm{AC}_{3}\right) \beta\right]-\mathrm{OH}$ & 599.20 & 599.30 & $27.29 \%$ \\
Fmoc-Ser[D-Xyl $\left.\left(\mathrm{AC}_{4}\right) \beta\right]-\mathrm{OH}$ & 585.18 & 585.20 & $23.81 \%$ \\
Fmoc-Ser[L-Xyl $\left.\left(\mathrm{AC}_{4}\right) \beta\right]-\mathrm{OH}$ & 585.18 & 585.20 & $18.26 \%$ \\
Fmoc-Ser[Man $\left.\left(\mathrm{AC}_{4}\right) \alpha\right]-\mathrm{OH}$ & 657.21 & 657.30 & $21.67 \%$ \\
Fmoc-Ser[Rha $\left.\left(\mathrm{AC}_{4}\right) \alpha\right]-\mathrm{OH}$ & 599.20 & 599.19 & $24.25 \%$ \\
Fmoc-Ser[D-Arb $\left.\left(\mathrm{AC}_{4}\right) \alpha\right]-\mathrm{OH}$ & 585.18 & 585.10 & $20.28 \%$ \\
Fmoc-Ser[L-Arb $\left.\left(\mathrm{AC}_{4}\right) \alpha\right]-\mathrm{OH}$ & 585.18 & 585.20 & $17.63 \%$ \\
Fmoc-Ser[D-Rib(AC 4$) \alpha]-\mathrm{OH}$ & 585.18 & 585.18 & $22.18 \%$ \\
Fmoc-Ser[L-Rib $\left.\left(\mathrm{AC}_{4}\right) \alpha\right]-\mathrm{OH}$ & 585.18 & 585.18 & $23.54 \%$ \\
\hline
\end{tabular}

Table S2: MS data for HYL and its analogues

\begin{tabular}{ccc}
\hline Peptide & MS(Calcd) & MS(found) \\
\hline HYL & 1696.98 & 1697.00 \\
HYL-14 & 1806.08 & 1806.09 \\
HYL-19 & 2009.16 & 2008.80 \\
HYL-20 & 2009.16 & 2008.80 \\
HYL-21 & 2212.24 & 2212.00 \\
HYL-22 & 1968.13 & 1968.40 \\
HYL-23 & 1968.13 & 1968.40 \\
HYL-24 & 2130.19 & 2130.60 \\
HYL-25 & 1968.13 & 1968.40 \\
HYL-26 & 1968.13 & 1968.40 \\
HYL-27 & 2130.19 & 2130.40 \\
HYL-28 & 1938.12 & 1937.60 \\
HYL-29 & 1938.12 & 1937.80 \\
\hline
\end{tabular}




\begin{tabular}{lll}
\hline HYL-30 & 1938.12 & 1937.60 \\
HYL-31 & 1938.12 & 1937.80 \\
HYL-32 & 1968.13 & 1968.20 \\
HYL-33 & 1952.14 & 1951.80 \\
HYL-34 & 1938.12 & 1938.13 \\
HYL-35 & 1938.12 & 1938.13 \\
HYL-36 & 1952.14 & 1952.15 \\
HYL-37 & 1806.08 & 1806.09 \\
HYL-38 & 1806.08 & 1806.09 \\
HYL-39 & 1806.08 & 1806.09 \\
HYL-40 & 1806.08 & 1806.10 \\
HYL-41 & 1806.08 & 1806.10 \\
HYL-42 & 1806.08 & 1806.10 \\
HYL-43 & 1806.08 & 1806.09 \\
\hline
\end{tabular}

Table S3: The antitumor activity of peptides

\begin{tabular}{lcccc}
\hline peptide & RT(min) & \multicolumn{3}{c}{$\mathrm{IC}_{50}(\mu \mathrm{M})$} \\
\cline { 3 - 5 } & & MCF-7 & HepG2 & HCT116 \\
\hline HYL & 15.784 & $13.13 \pm 0.27$ & $14.71 \pm 0.42$ & $22.89 \pm 0.22$ \\
HYL-14 & 18.499 & $1.58 \pm 0.35$ & $1.67 \pm 0.25$ & $1.61 \pm 0.27$ \\
HYL-19 & 17.435 & $1.85 \pm 0.23$ & $1.23 \pm 0.46$ & $2.74 \pm 0.42$ \\
HYL-20 & 17.801 & $2.19 \pm 0.29$ & $4.30 \pm 0.22$ & $3.96 \pm 0.35$ \\
HYL-21 & 17.141 & $4.58 \pm 0.45$ & $9.70 \pm 0.39$ & $3.83 \pm 0.12$ \\
HYL-22 & 17.954 & $1.39 \pm 0.38$ & $1.03 \pm 0.21$ & $1.32 \pm 0.15$ \\
HYL-23 & 17.810 & $3.26 \pm 0.41$ & $1.29 \pm 0.25$ & $2.29 \pm 0.31$ \\
HYL-24 & 17.160 & $23.73 \pm 0.53$ & $3.34 \pm 0.18$ & $4.69 \pm 0.28$ \\
HYL-25 & 16.698 & $1.07 \pm 0.33$ & $1.61 \pm 0.22$ & $2.35 \pm 0.42$ \\
HYL-26 & 16.901 & $1.73 \pm 0.14$ & $2.90 \pm 0.37$ & $2.92 \pm 0.39$ \\
HYL-27 & 16.037 & $3.34 \pm 0.25$ & $3.38 \pm 0.27$ & $4.57 \pm 0.19$ \\
\hline
\end{tabular}




\begin{tabular}{lllll}
\hline HYL-28 & 16.884 & $0.71 \pm 0.24$ & $1.55 \pm 0.35$ & $1.66 \pm 0.54$ \\
HYL-29 & 16.883 & $0.84 \pm 0.23$ & $1.23 \pm 0.42$ & $1.60 \pm 0.49$ \\
HYL-30 & 16.919 & $1.26 \pm 0.14$ & $0.77 \pm 0.37$ & $2.30 \pm 0.29$ \\
HYL-31 & 17.294 & $0.43 \pm 0.27$ & $0.75 \pm 0.36$ & $0.63 \pm 0.41$ \\
HYL-32 & 16.502 & $0.86 \pm 0.52$ & $1.17 \pm 0.28$ & $2.52 \pm 0.33$ \\
HYL-33 & 17.496 & $0.85 \pm 0.24$ & $1.04 \pm 0.17$ & $2.48 \pm 0.49$ \\
HYL-34 & 17.259 & $0.73 \pm 0.28$ & $1.33 \pm 0.31$ & $4.04 \pm 0.18$ \\
HYL-35 & 16.991 & $0.56 \pm 0.21$ & $1.12 \pm 0.23$ & $0.90 \pm 0.42$ \\
HYL-36 & 17.046 & $1.31 \pm 0.30$ & $1.47 \pm 0.25$ & $3.47 \pm 0.15$ \\
HYL-37 & 17.727 & $1.96 \pm 0.24$ & $2.72 \pm 0.43$ & $3.38 \pm 0.19$ \\
HYL-38 & 18.424 & $1.52 \pm 0.13$ & $2.31 \pm 0.33$ & $3.38 \pm 0.47$ \\
HYL-39 & 18.138 & $1.73 \pm 0.28$ & $3.12 \pm 0.26$ & $2.62 \pm 0.36$ \\
HYL-40 & 15.448 & $2.90 \pm 0.21$ & $3.68 \pm 0.35$ & $4.32 \pm 0.26$ \\
HYL-41 & 15.640 & $1.38 \pm 0.29$ & $2.12 \pm 0.31$ & $2.39 \pm 0.43$ \\
HYL-42 & 16.080 & $1.35 \pm 0.18$ & $2.60 \pm 0.23$ & $2.96 \pm 0.38$ \\
HYL-43 & 15.574 & $9.48 \pm 0.24$ & $6.87 \pm 0.18$ & $3.36 \pm 0.27$ \\
\hline
\end{tabular}

Table S4: The antimicrobial and hemolytic activity of peptides

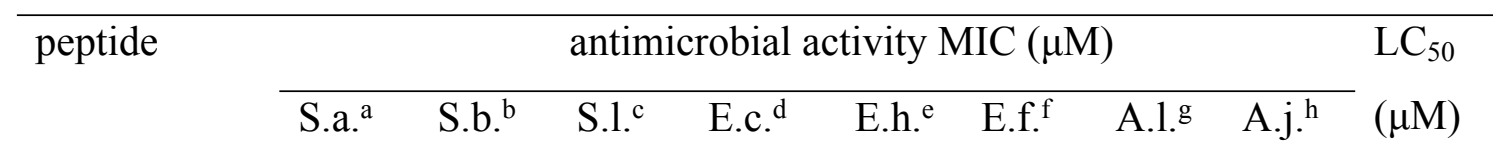




\begin{tabular}{|c|c|c|c|c|c|c|c|c|c|}
\hline HYL & 55 & 60 & 0.78 & 3.2 & $>100$ & 25 & 52 & 6.8 & $>400$ \\
\hline HYL-14 & 6.3 & 7.2 & 0.12 & 0.26 & 3.2 & 0.78 & 3.8 & 3.2 & 125 \\
\hline HYL-19 & 6.5 & 12 & 1.5 & 0.32 & 25 & 1.2 & 3.2 & 2.4 & $>400$ \\
\hline HYL-20 & 6.1 & 10 & 3.1 & 0.21 & 6.2 & 3.2 & 3.0 & 2.8 & 150 \\
\hline HYL-21 & 3.0 & 25 & 0.78 & 0.15 & 24 & 25 & 3.5 & 6.2 & 178 \\
\hline HYL-22 & 5.7 & 29 & 1.6 & 0.27 & 6.0 & 2.8 & 6.5 & 6.8 & 225 \\
\hline HYL-23 & 2.9 & 13 & 1.6 & 0.41 & 5.8 & 2.4 & 1.5 & 3.0 & 139 \\
\hline HYL-24 & 6.8 & 22 & 0.58 & 0.26 & 12 & 2.9 & 3.0 & 3.2 & 142 \\
\hline HYL-25 & 2.6 & 9 & 1.8 & 0.28 & 2.8 & 3.4 & 1.7 & 0.53 & 180 \\
\hline HYL-26 & 2.8 & 16 & 1.2 & 0.35 & 6.5 & 6.0 & 5.8 & 1.5 & $>400$ \\
\hline HYL-27 & 7.0 & 12 & 1.4 & 3.0 & 10 & 3.6 & 12 & 13 & $>400$ \\
\hline HYL-28 & 3.4 & 25 & 3.1 & 0.38 & 6.5 & 1.2 & 1.3 & 3.2 & 135 \\
\hline HYL-29 & 3.2 & 26 & 1.5 & 0.32 & 6.0 & 1.3 & 1.6 & 6.1 & 163 \\
\hline HYL-30 & 2.8 & 10 & 1.2 & 0.26 & 12 & 6.8 & 3.0 & 5.6 & 168 \\
\hline HYL-31 & 3.6 & 28 & 1.8 & 0.35 & 5.9 & 3.2 & 3.5 & 3.0 & $>400$ \\
\hline HYL-32 & 3.2 & 18 & 0.15 & 1.6 & 6.3 & 1.5 & 1.6 & 2.9 & $>400$ \\
\hline HYL-33 & 3.2 & 6.0 & 0.12 & 0.30 & 6.5 & 0.24 & 0.78 & 3.5 & $>400$ \\
\hline HYL-34 & 12 & 100 & 3.0 & 3.1 & 25 & 6.2 & 6.1 & 1.1 & $>400$ \\
\hline HYL-35 & 6.5 & 51 & 3.5 & 1.8 & 22 & 6.0 & 3.5 & 1.2 & 180 \\
\hline HYL-36 & 6.2 & 24 & 1.5 & 2.8 & 26 & 3.2 & 1.6 & 0.76 & 176 \\
\hline HYL-37 & 3.2 & 13 & 1.5 & 3.0 & 13 & 3.1 & 3.2 & 0.54 & $>400$ \\
\hline HYL-38 & 3.6 & 11 & 1.7 & 2.8 & 9.5 & 3.6 & 2.6 & 0.67 & $>400$ \\
\hline HYL-39 & 6.2 & 15 & 1.3 & 0.72 & 11 & 6.2 & 3.2 & 1.3 & $>400$ \\
\hline HYL-40 & 12 & 52 & 1.3 & 3.9 & 25 & 2.7 & 1.5 & 0.68 & $>400$ \\
\hline HYL-41 & 6.5 & 12 & 1.5 & 0.69 & 13 & 6.25 & 3.0 & 0.39 & 186 \\
\hline HYL-42 & 2.0 & 8.3 & 2.1 & 0.12 & 8.3 & 2.2 & 1.0 & 0.52 & 182 \\
\hline HYL-43 & 26 & 48 & 0.78 & 6.3 & 52 & 12 & 24 & 0.78 & 168 \\
\hline Ampicillin & 3.2 & $>100$ & 0.72 & 25 & $>100$ & 48 & 1.5 & $>100$ & n.t. ${ }^{j}$ \\
\hline Streptomycin & 0.78 & $>100$ & $<0.1$ & 50 & $>100$ & $>100$ & $<0.1$ & $>100$ & n.t. \\
\hline
\end{tabular}

${ }^{\mathrm{a} S}$.a., Staphylococcus aureus; ${ }^{\mathrm{b} S . b ., ~ S a l m o n e l l a ~ b o n g o r i ; ~}{ }^{\mathrm{c} S . l .,}$ Staphylococcus lentus; ${ }^{\mathrm{d}}$ E.c., Enterococcus casseliflavus; ${ }^{\mathrm{e}}$ E.h., Enterococcus hirae; ${ }^{\mathrm{f}}$ E.f., Enterococcus faecalis; ${ }^{\mathrm{g}}$ A.l., Acinetobacter lwoffii; ${ }^{\mathrm{h}}$ A.j., Acinetobacter johnsonii. 
Table S5: The $\alpha$-helicity (\%) of peptides in PBS buffer and membrane-like milieu (WF)

\begin{tabular}{|c|c|c|}
\hline Peptide & PBS helicity & $\mathrm{WF}_{\text {helicity }}$ \\
\hline HYL & -- & 79.5 \\
\hline HYL-14 & 34.2 & 84.7 \\
\hline HYL-19 & 34.5 & 88.1 \\
\hline HYL-20 & 41.9 & 82.5 \\
\hline HYL-21 & 28.1 & 90.8 \\
\hline HYL-22 & 37.7 & 93.4 \\
\hline HYL-23 & 40.2 & 84.3 \\
\hline HYL-24 & 35.1 & 87.4 \\
\hline HYL-25 & 37.5 & 81.4 \\
\hline HYL-26 & 61.0 & 92.8 \\
\hline HYL-27 & 37.4 & 76.4 \\
\hline HYL-28 & 36.6 & 76.6 \\
\hline HYL-29 & 39.6 & 80.7 \\
\hline HYL-30 & 36.3 & 68.9 \\
\hline HYL-31 & 43.7 & 90.3 \\
\hline HYL-32 & 45.5 & 94.1 \\
\hline HYL-33 & 44.6 & 94.0 \\
\hline HYL-34 & 49.9 & 98.3 \\
\hline HYL-35 & 41.9 & 86.2 \\
\hline HYL-36 & 39.8 & 80.1 \\
\hline HYL-37 & 19.4 & 39.4 \\
\hline HYL-38 & 19.2 & 52.6 \\
\hline HYL-39 & 26.8 & 71.0 \\
\hline HYL-40 & 18.4 & 38.0 \\
\hline HYL-41 & 16.8 & 53.7 \\
\hline HYL-42 & 14.4 & 46.2 \\
\hline
\end{tabular}




\begin{tabular}{lll}
\hline HYL-43 & 6.7 & 45.4 \\
\hline
\end{tabular}

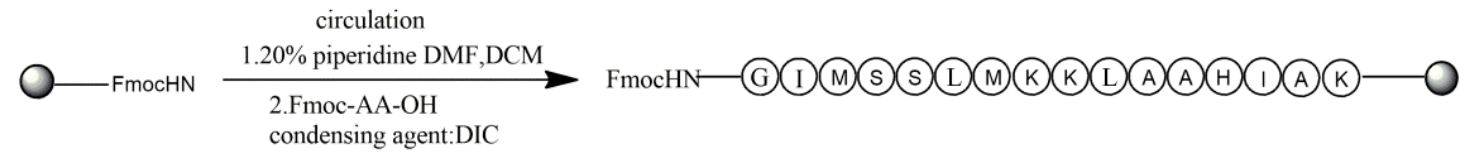

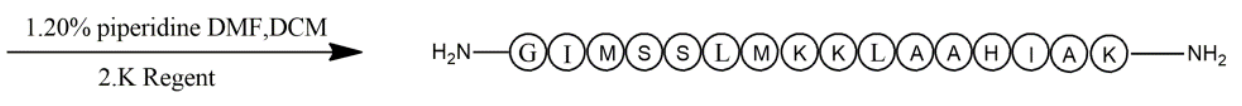

Scheme S1. Schematic diagram of the linear peptide HYL synthesis

A

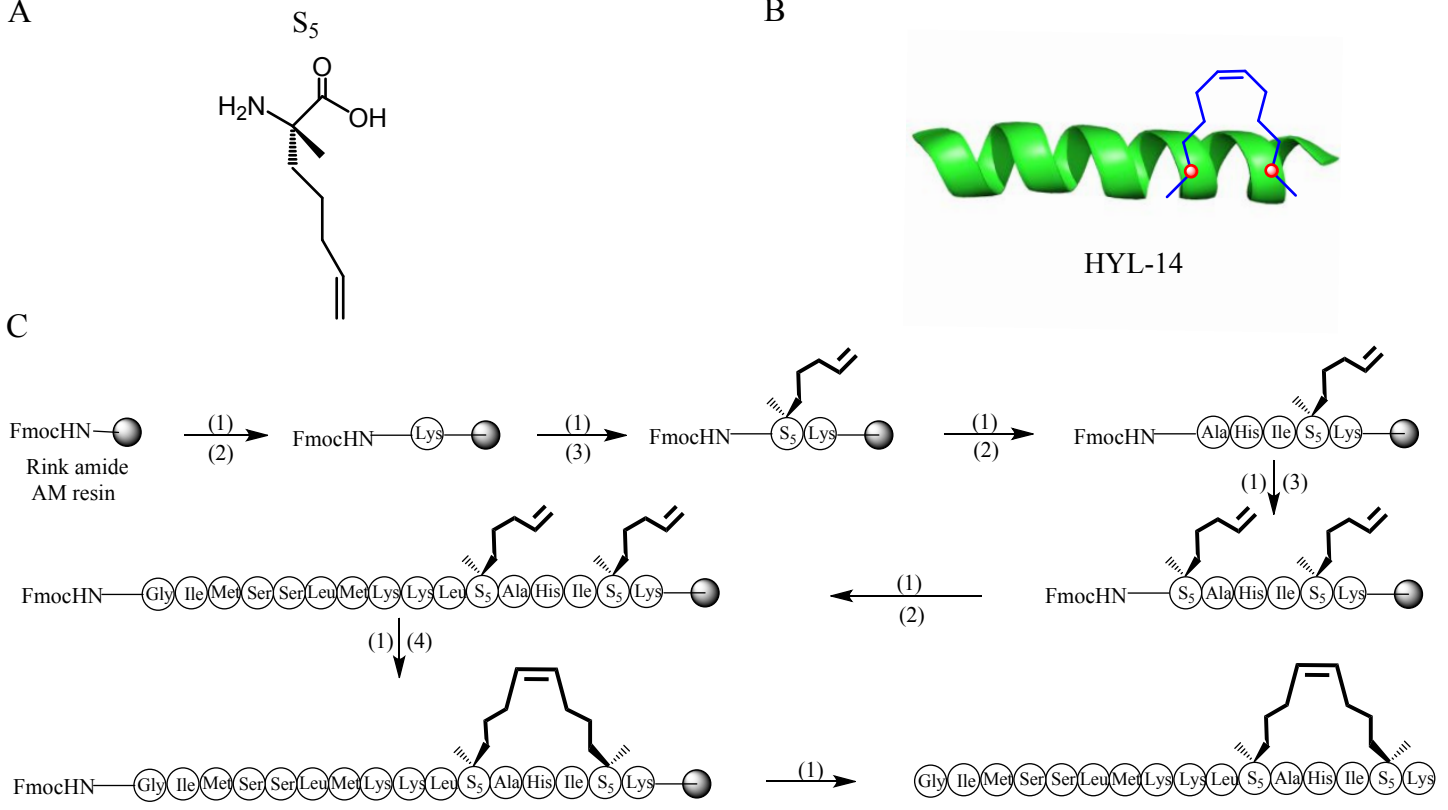

$\mathrm{B}$

HYL-14

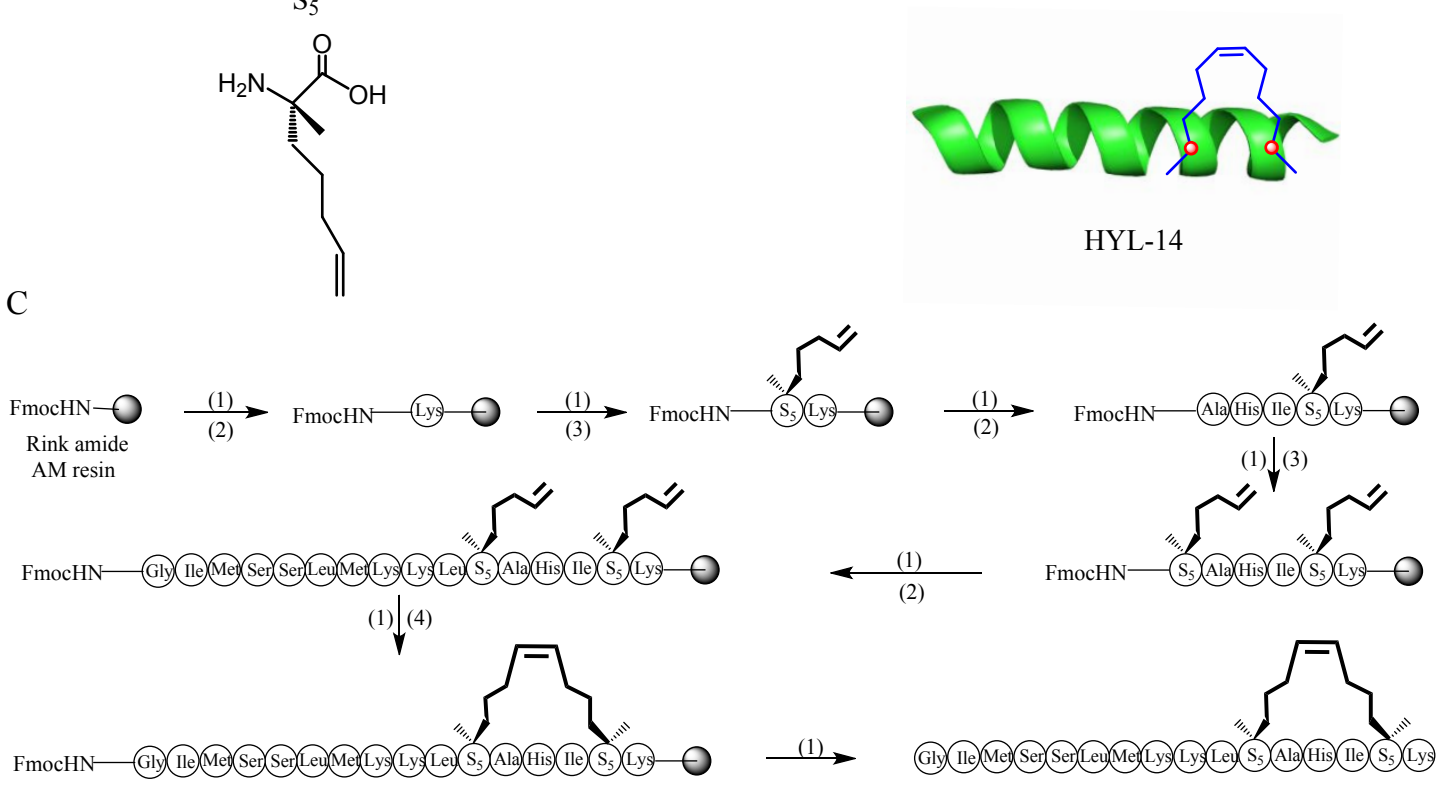

$\mathrm{C}$

Figure S1. Structures of $\mathrm{S}_{5}(\mathrm{~A})$ and the stapled peptides HYL-14 (B). Synthesis of the stapled peptide HYL-14 (C). Conditions: (1) $20 \%$ piperidine in DMF 5 min (2 times), $35{ }^{\circ} \mathrm{C}$; (2) Fmoc-AA-OH (4 equiv.)/HCTU (4 equiv.)/DIEA (4 equiv.), 1 h, $35^{\circ} \mathrm{C}$; (3) Fmoc-S $\mathrm{S}_{5}-\mathrm{OH}(4$ equiv.)/HATU (4 equiv.)/HOAT (4 equiv.)/DIEA (4 equiv.), 2 h, $35^{\circ} \mathrm{C}$; (4) 6 mmol/L 1st Grubbs', catalyst, DCE, $2 \mathrm{~h}, 35^{\circ} \mathrm{C}$; (5) reagent $\mathrm{K}\left(\mathrm{TFA} / \mathrm{H}_{2} \mathrm{O} / \mathrm{EDT} /\right.$ thioanisole/phenol = 82.5:5:2.5:5:5), $3 \mathrm{~h}$, $35^{\circ} \mathrm{C}$. 
(A)
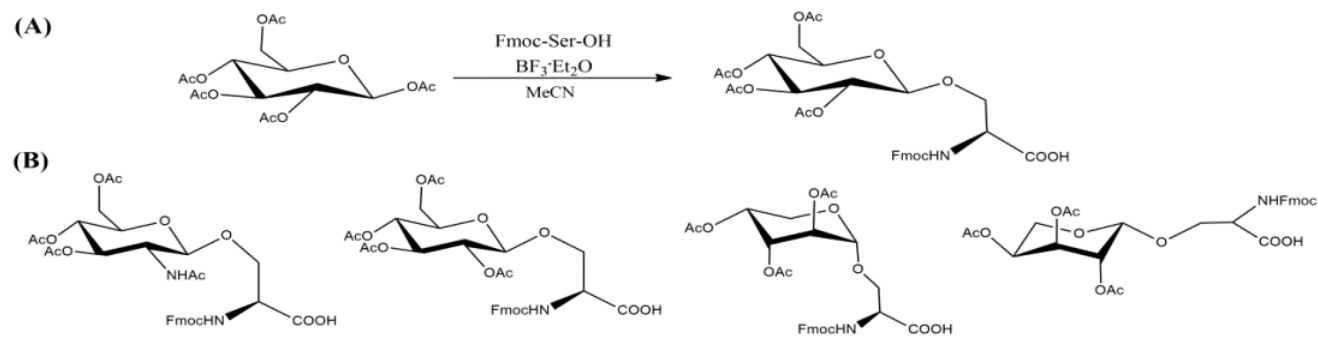

Fmoc-Ser[D-Glc $\left.\left(\mathrm{AC}_{3}\right) \mathrm{NAc} \beta\right]-\mathrm{OH}$

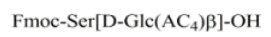

Fmoc-Ser[D-Arb $\left.\left(\mathrm{AC}_{4}\right) \alpha\right]-\mathrm{OH}$

Fmoc-Ser[L-Arb( $\left.\left(\mathrm{AC}_{4}\right) \alpha\right]-\mathrm{OH}$
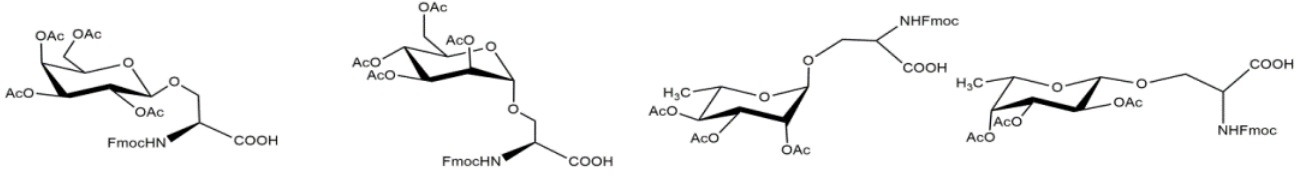

Fmoc-Ser[D-Gal $\left(\mathrm{AC}_{4}\right)$ B]-OH

Fmoc-Ser[D-Man $\left.\left(\mathrm{AC}_{4}\right) \alpha\right]-\mathrm{OH}$

Fmoc-Ser[L-Rha( $\left.\left.\mathrm{AC}_{4}\right) \alpha\right]-\mathrm{OH}$

Fmoc-Ser[L-Fuc( $\left.\left(\mathrm{AC}_{3}\right) \beta\right]-\mathrm{OH}$
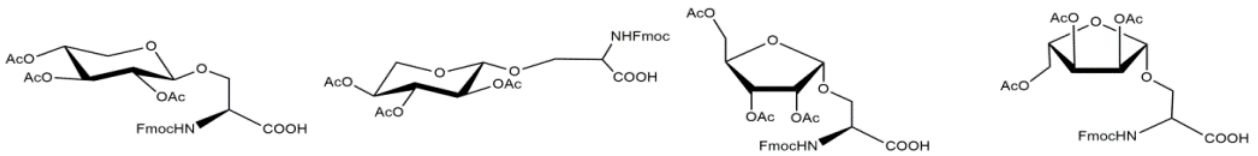

Fmoc-Ser[D-Xyl $\left.\left(\mathrm{AC}_{4}\right) \beta\right]-\mathrm{OH}$

Fmoc-Ser[L-Xyl( $\left.\left.\mathrm{AC}_{4}\right) \beta\right]-\mathrm{OH}$

Fmoc-Ser[D-Rib $\left.\left(\mathrm{AC}_{4}\right) \alpha\right]-\mathrm{OH}$

Fmoc-Ser[L-Rib( $\left.\left(\mathrm{AC}_{4}\right) \alpha\right]-\mathrm{OH}$

Figure S2: (A) Synthesis of glycoamino acids; (B) Structures of 12 glycoamino acids.

A

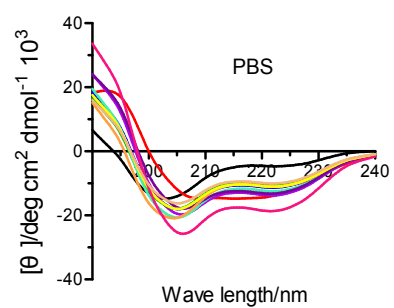

C

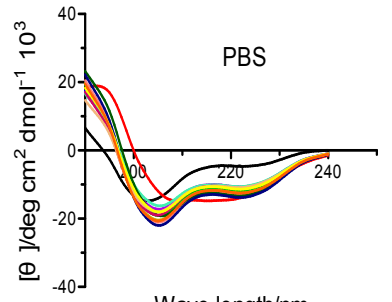

Wave length/nm

E

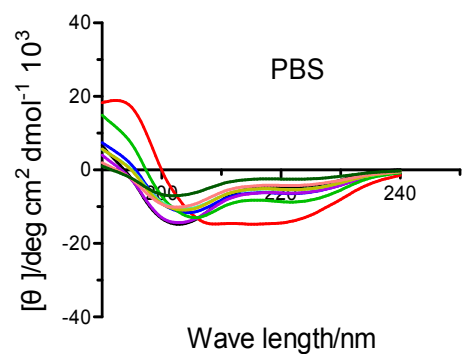

Wave length/nm

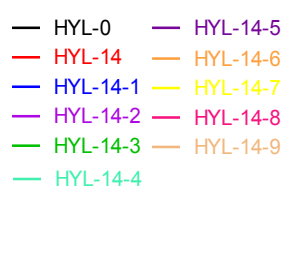

- $\mathrm{HYL}-14$

- HYL-14-2 - HYL-14-8

- HYL-14-4

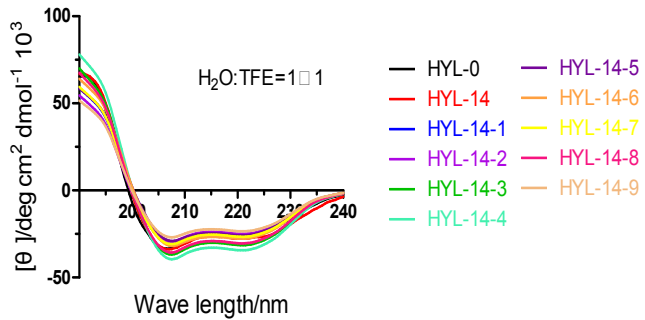

D

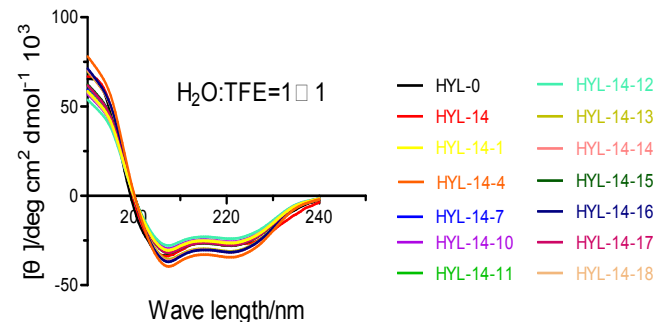

F

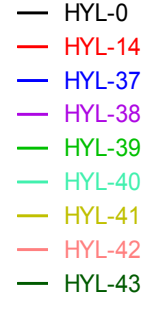

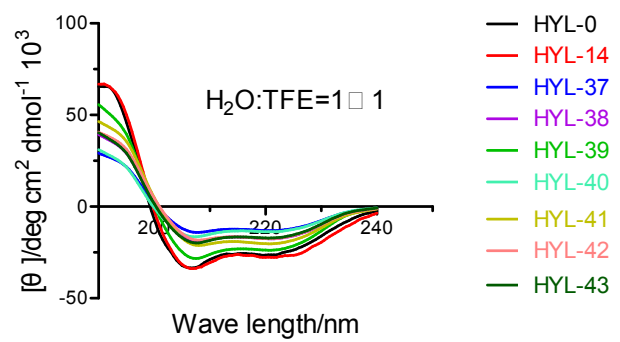


Figure S3. Circular dichroism (CD) spectroscopy of glycopeptides from HYL-19 to HYL-27 in PBS buffer (A) and membrane-like milieu (B). CD spectroscopy analysis of glycopeptides glycosylated at Ser4 in PBS buffer(C) and membrane-like milieu(D). CD spectroscopy analysis of HYL-37 to HYL-43 in PBS buffer (E) and membrane-like milieu (F).
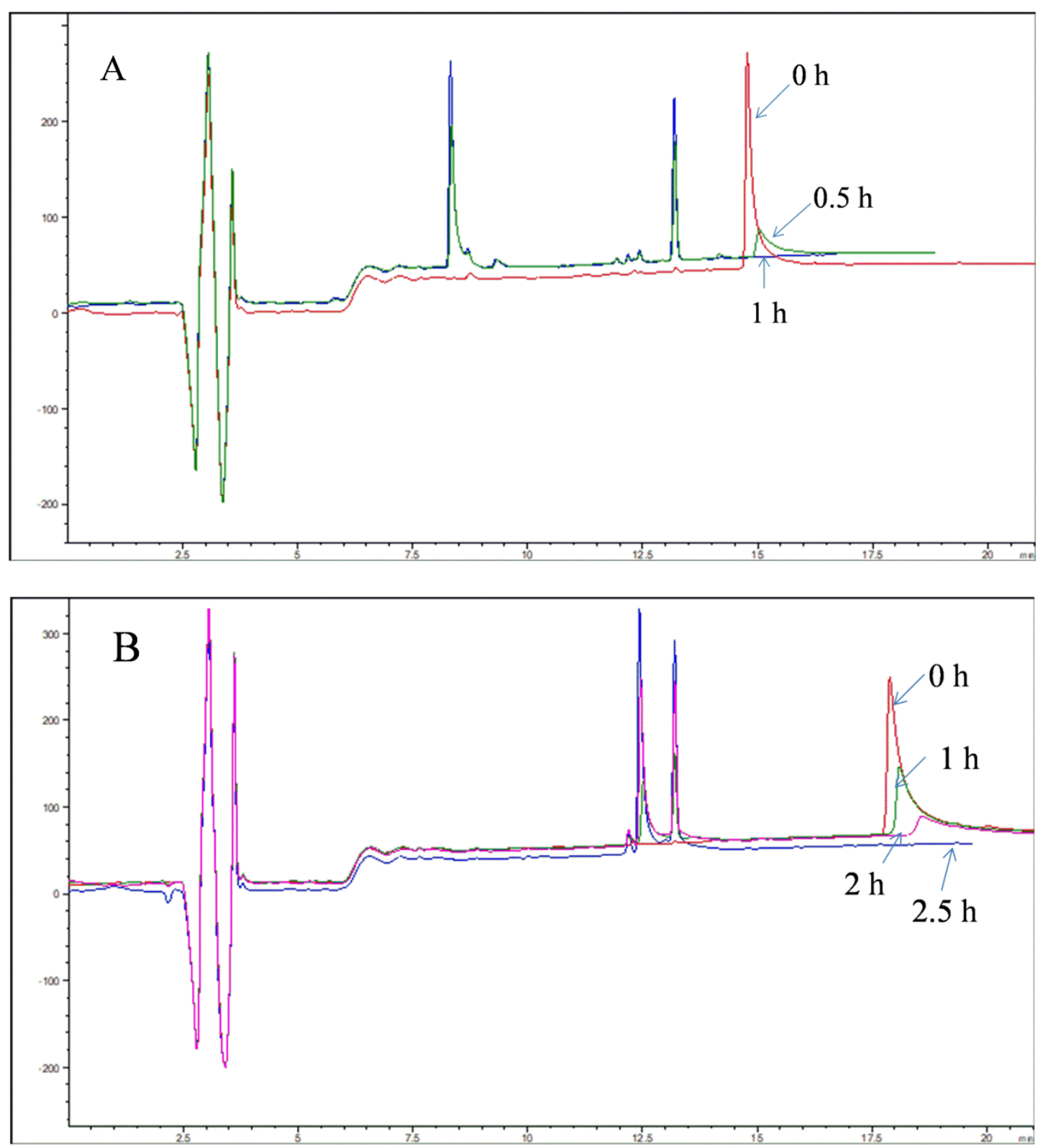

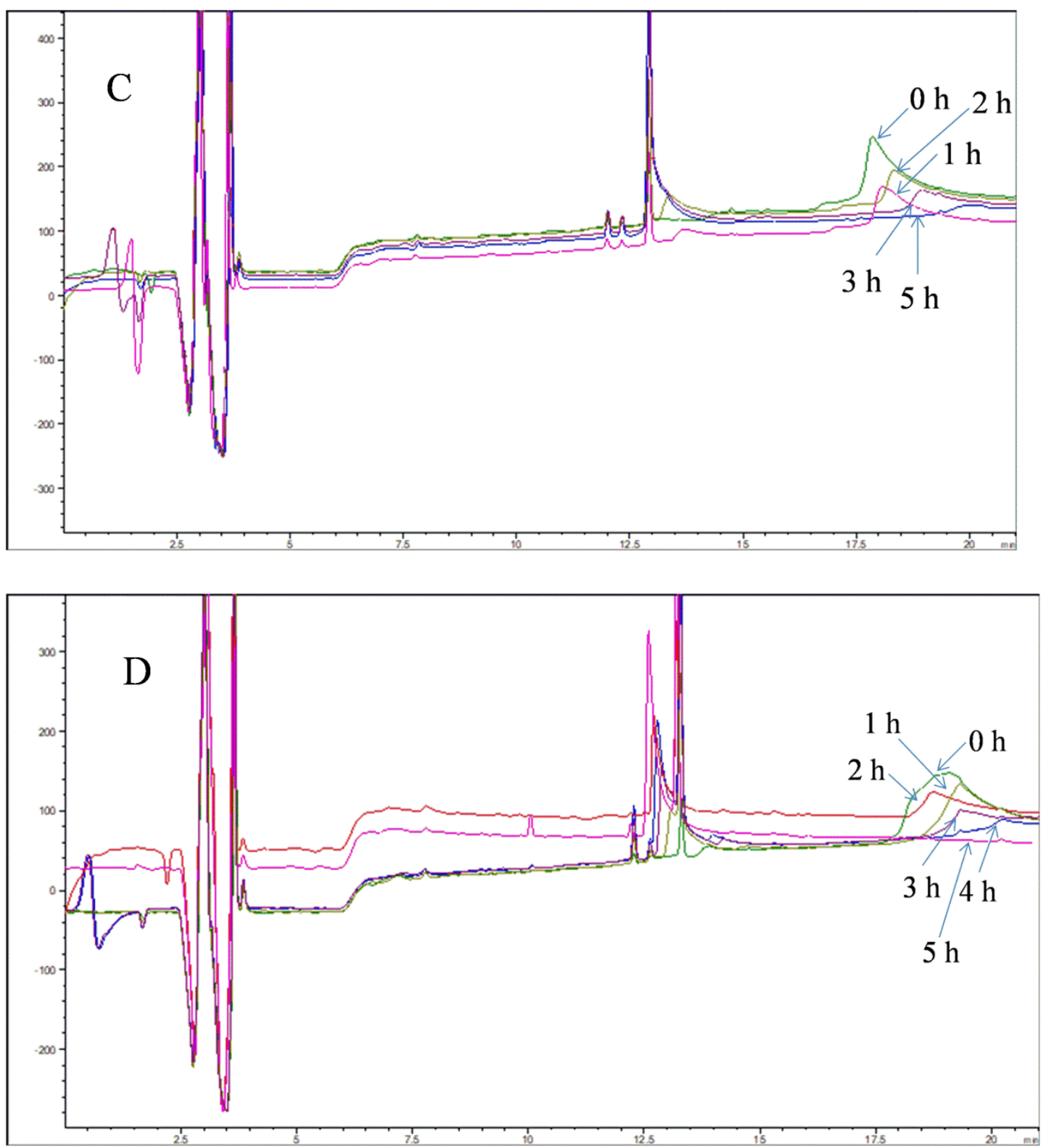

Figure S4. Analytical HPLC trace for proteolytic stability of HYL (A), HYL-14 (B), HYL-19 (C), and HYL-39 (D) incubated in chymotrypsin solution.

\section{Spectrum}

HPLC: X-coordinate: Mass-to-Charge (m/z), Y-coordinate: Abundance

Mass spectrum: X-coordinate: Retention Time(min), Y-coordinate:

Absorbance(mAU) 


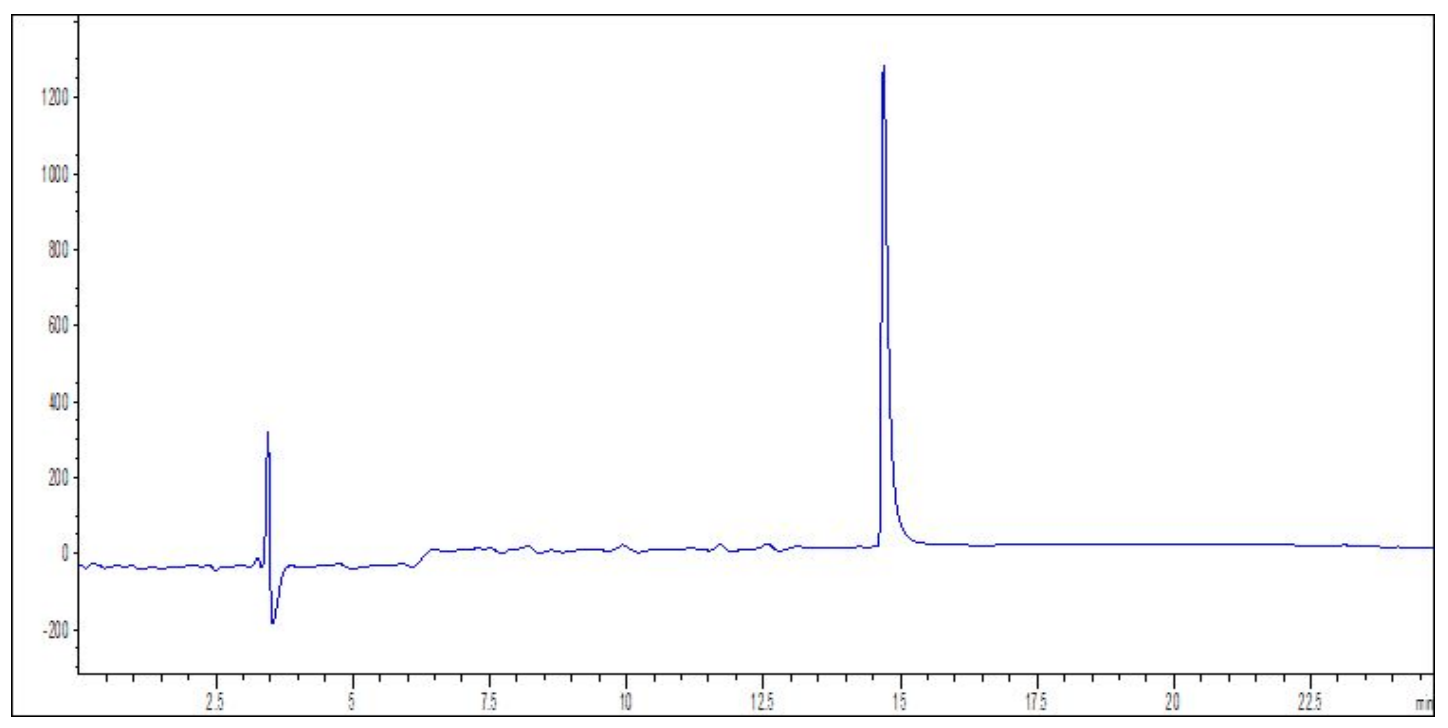

Fig. S5. Analytical HPLC trace for compound HYL

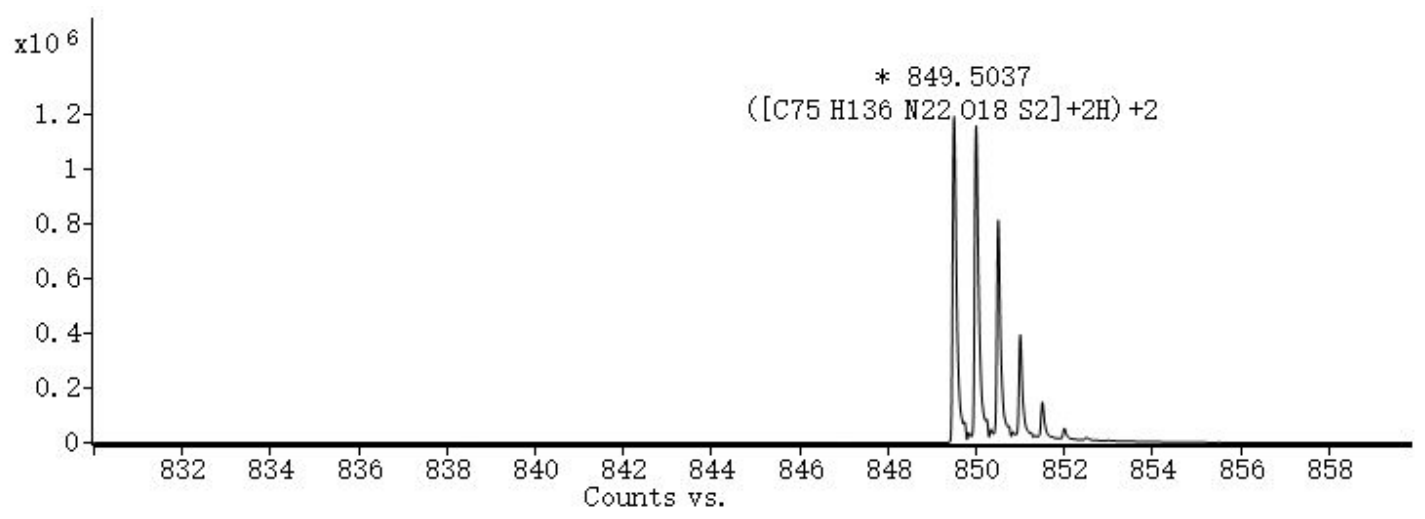

Fig. S6. Mass spectrum for compound HYL

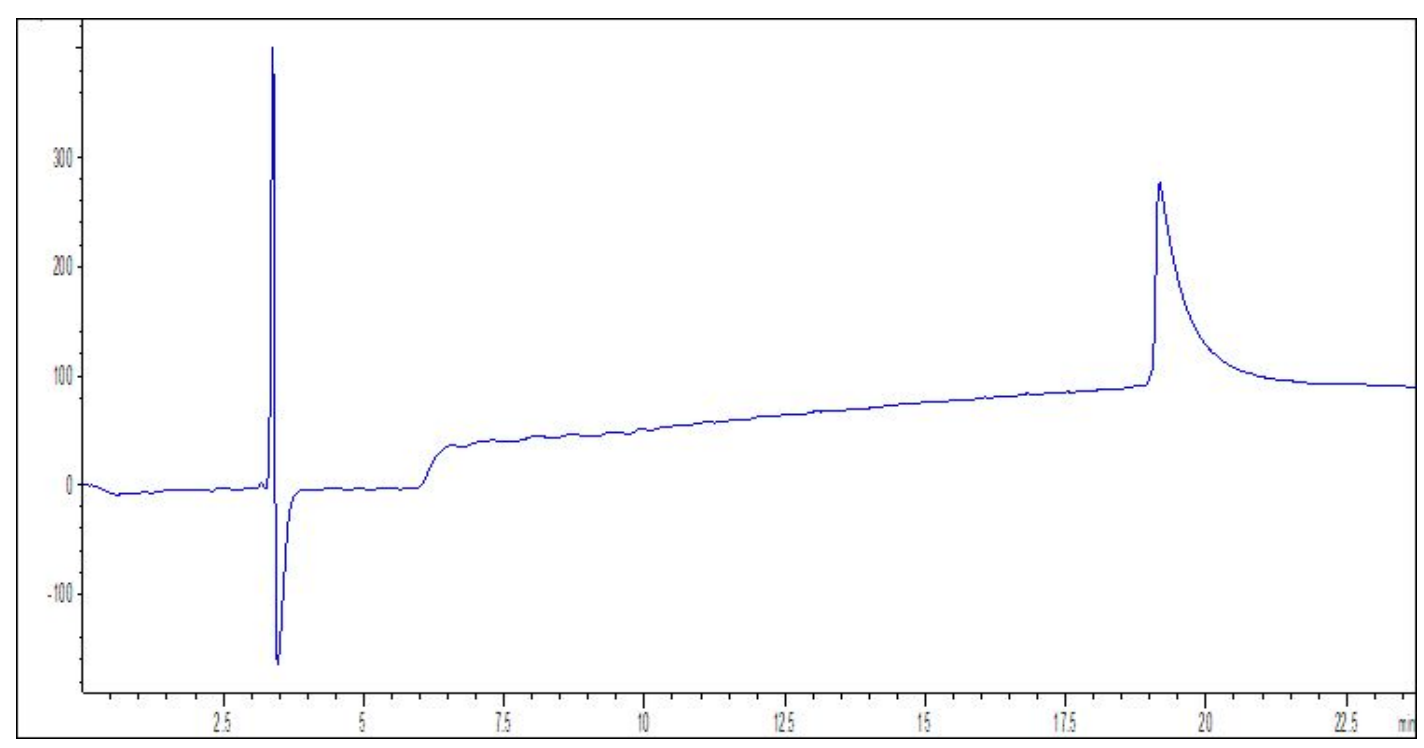

Fig. S7. Analytical HPLC trace for compound HYL-14 


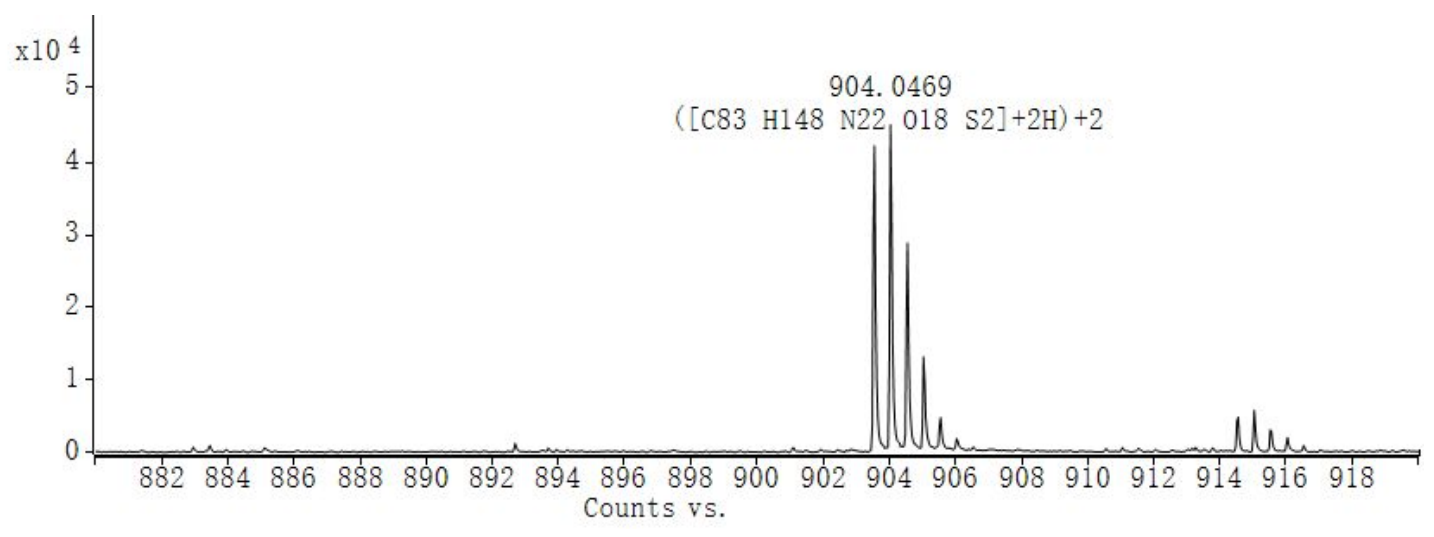

Fig. S8. Mass spectrum for compound HYL-14

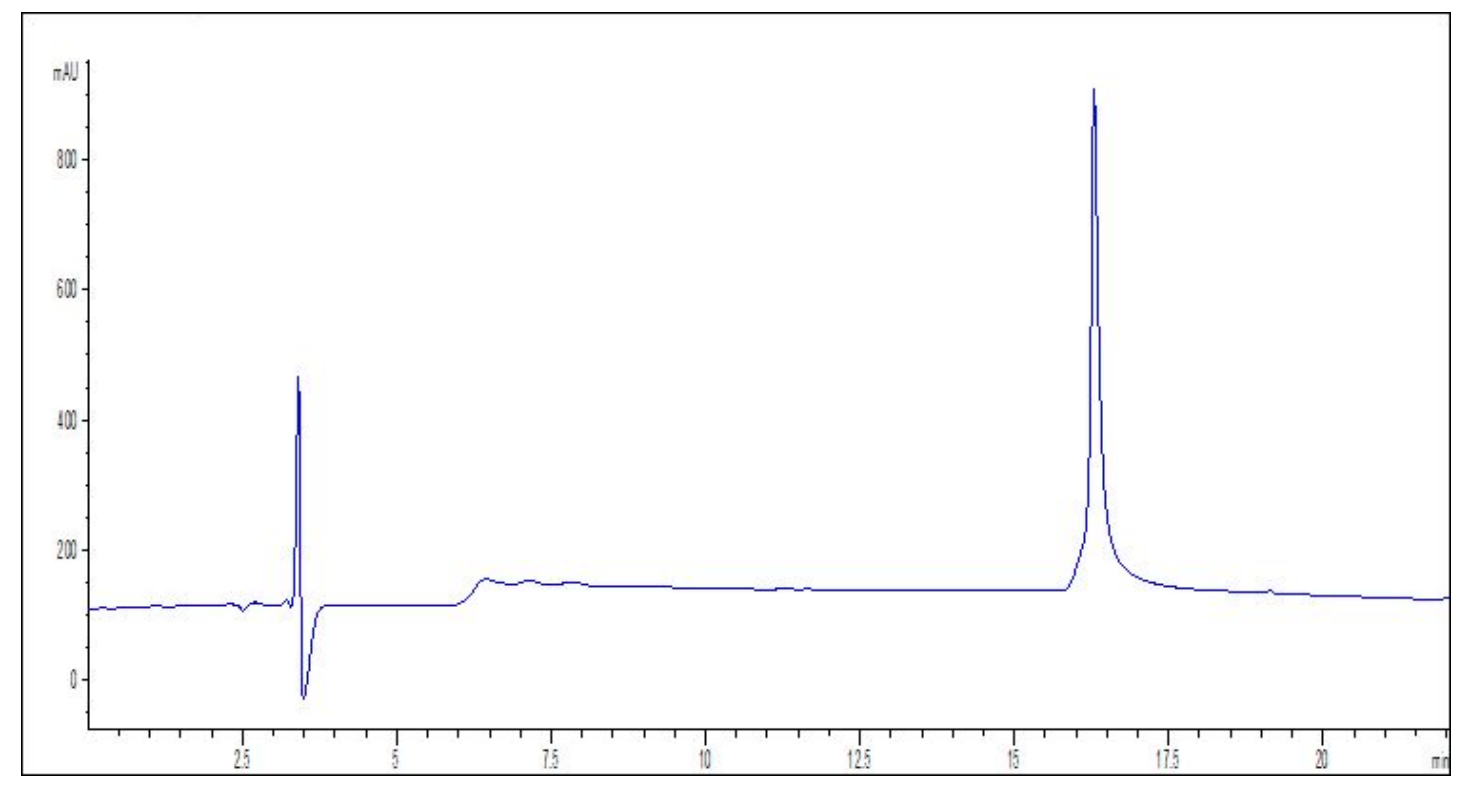

Figure S9. Analytical HPLC trace for compound HYL-19

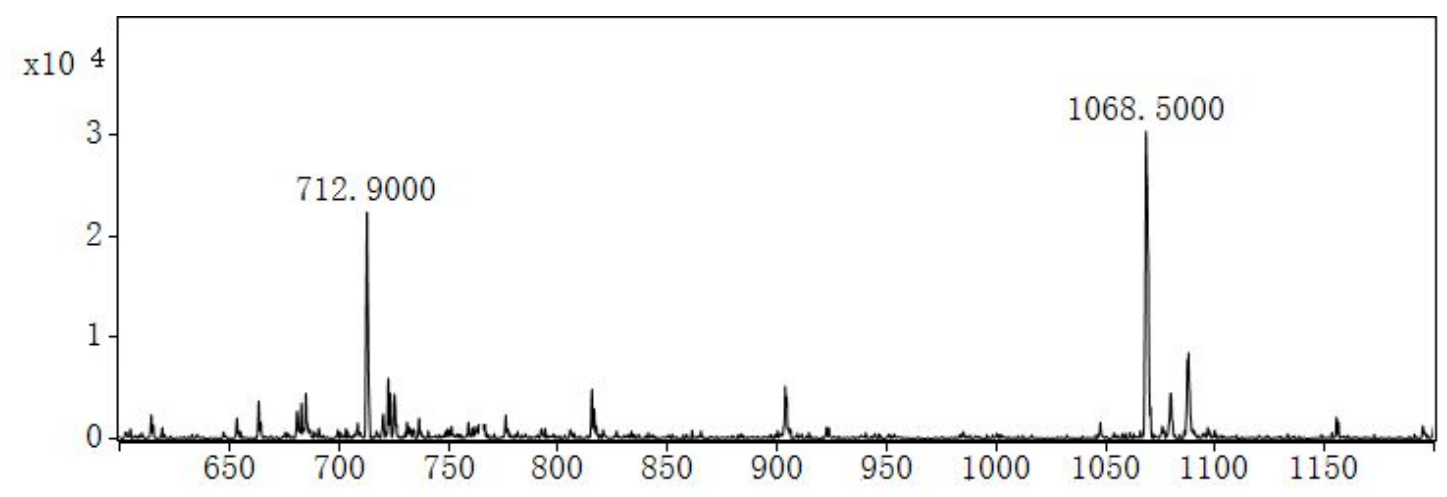

Figure S10. Mass spectrum for compound HYL-19 (Ac) 


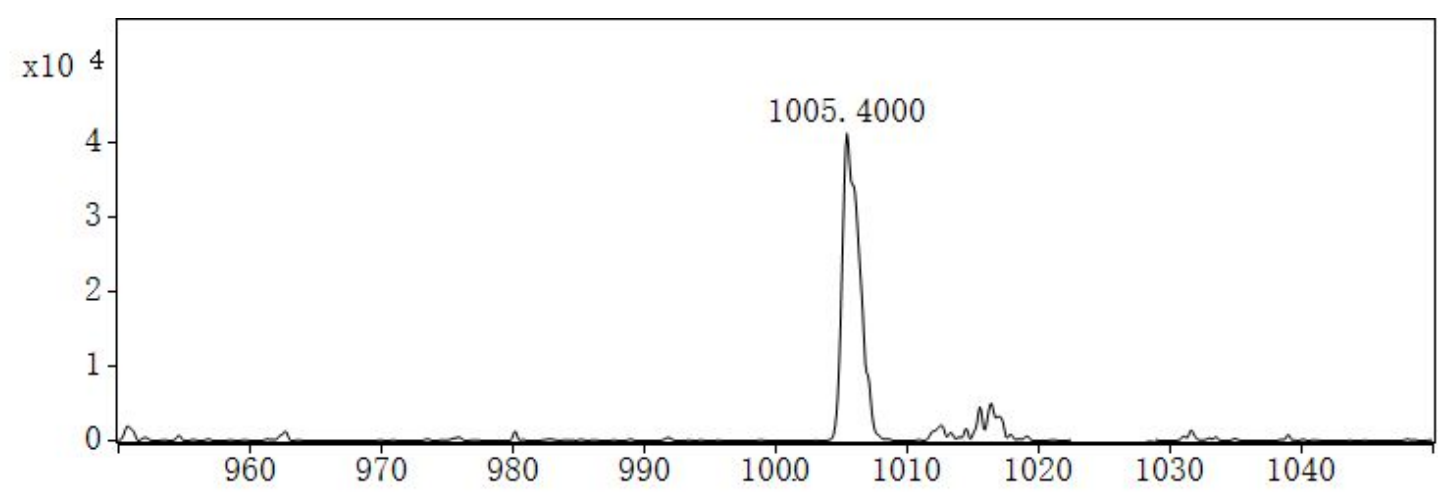

Figure S11. Mass spectrum for compound HYL-19

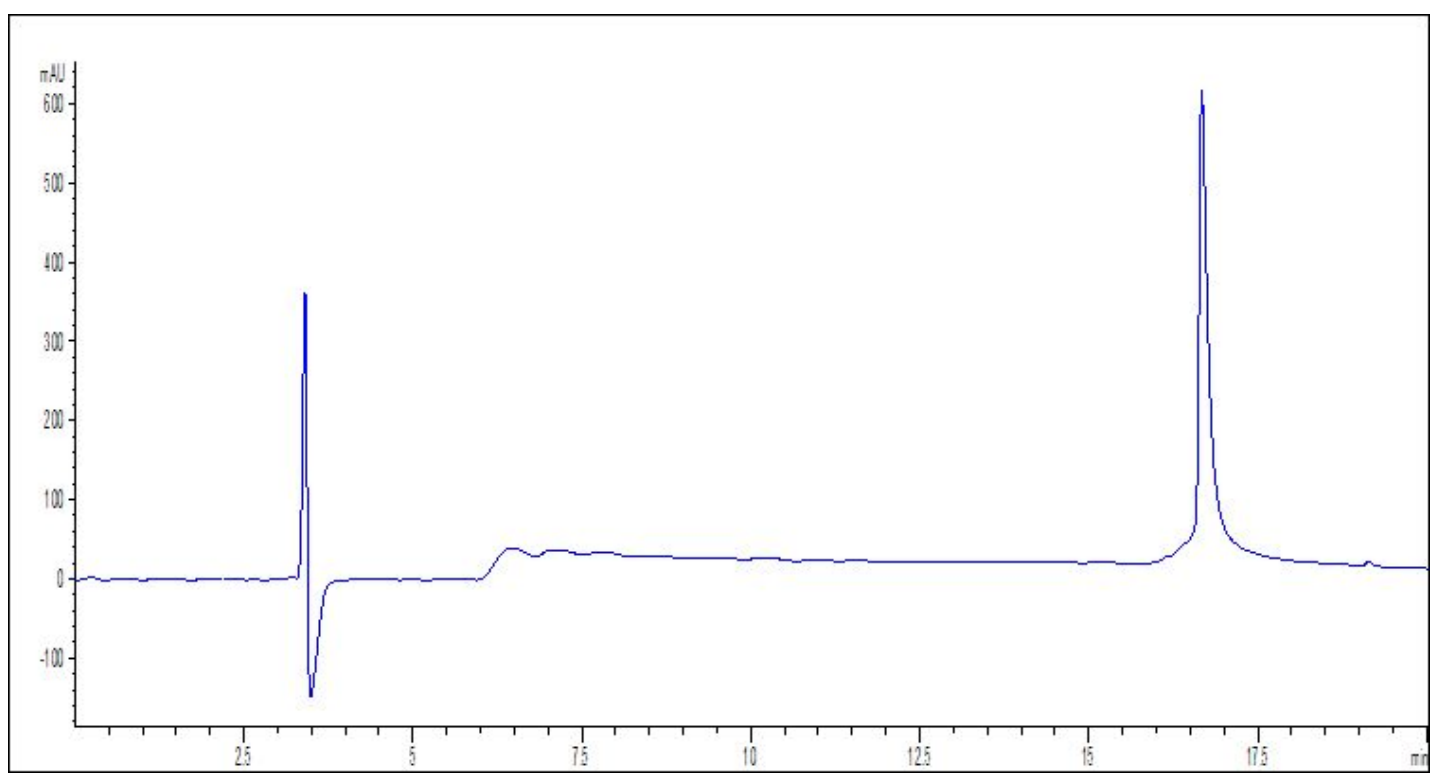

Figure S12. Analytical HPLC trace for compound HYL-20

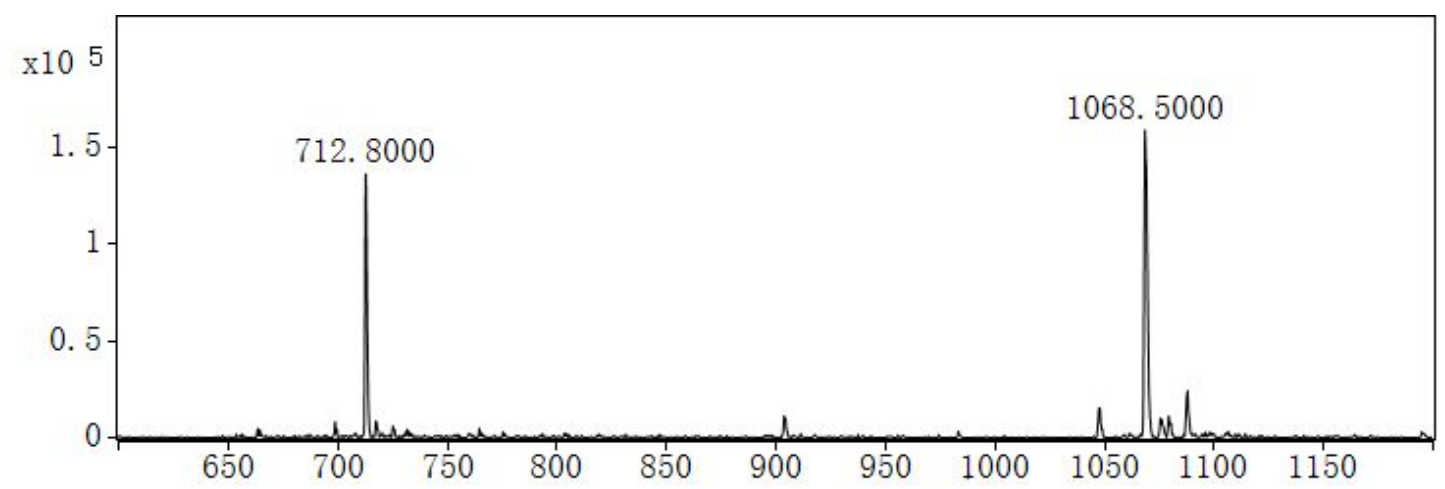

Figure S13. Mass spectrum for compound HYL-20（Ac） 


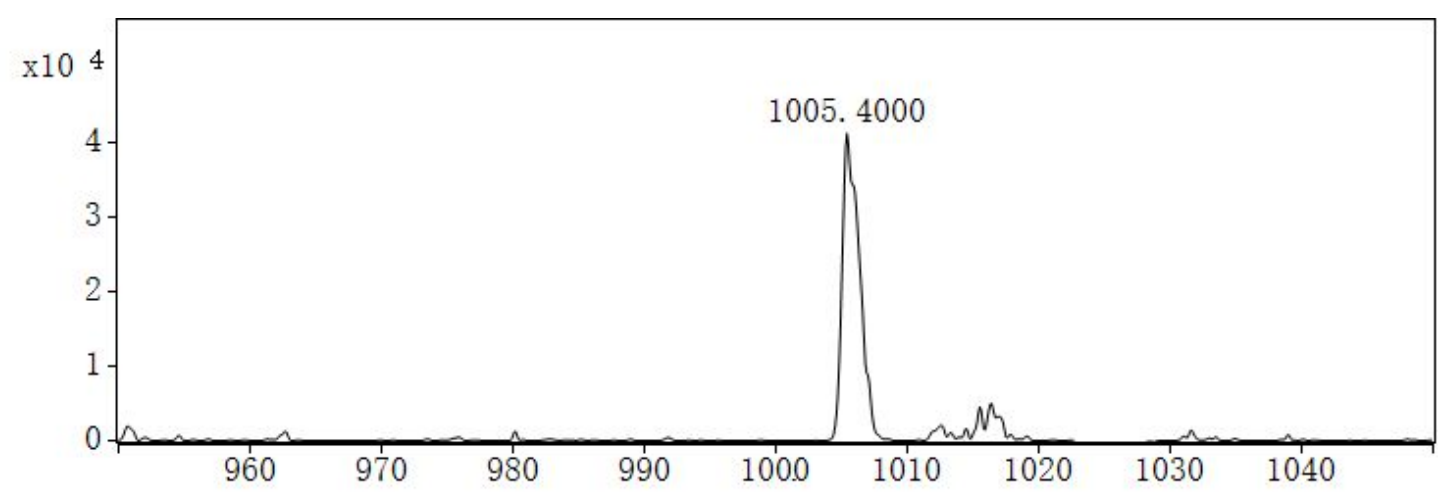

Figure S14. Mass spectrum for compound HYL-20

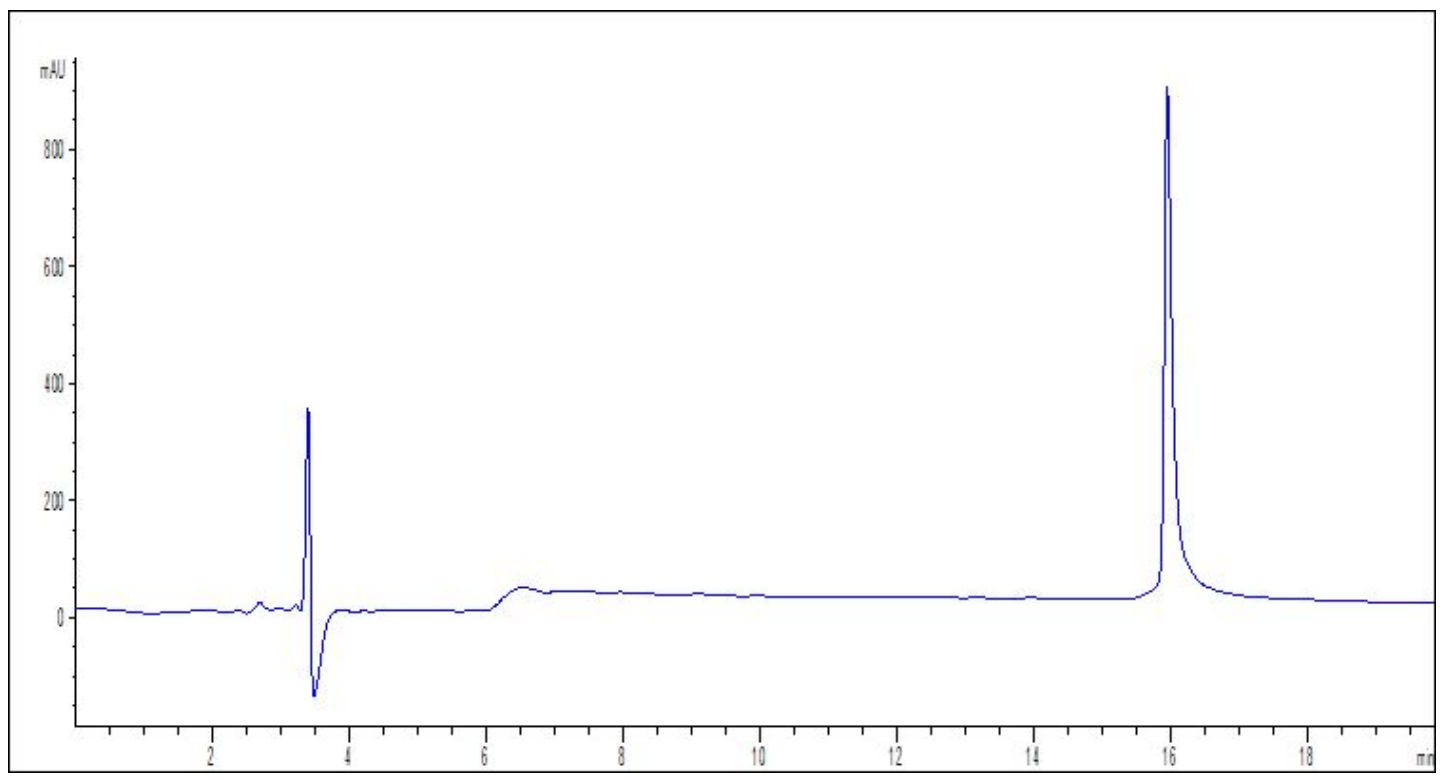

Figure S15. Analytical HPLC trace for compound HYL-21

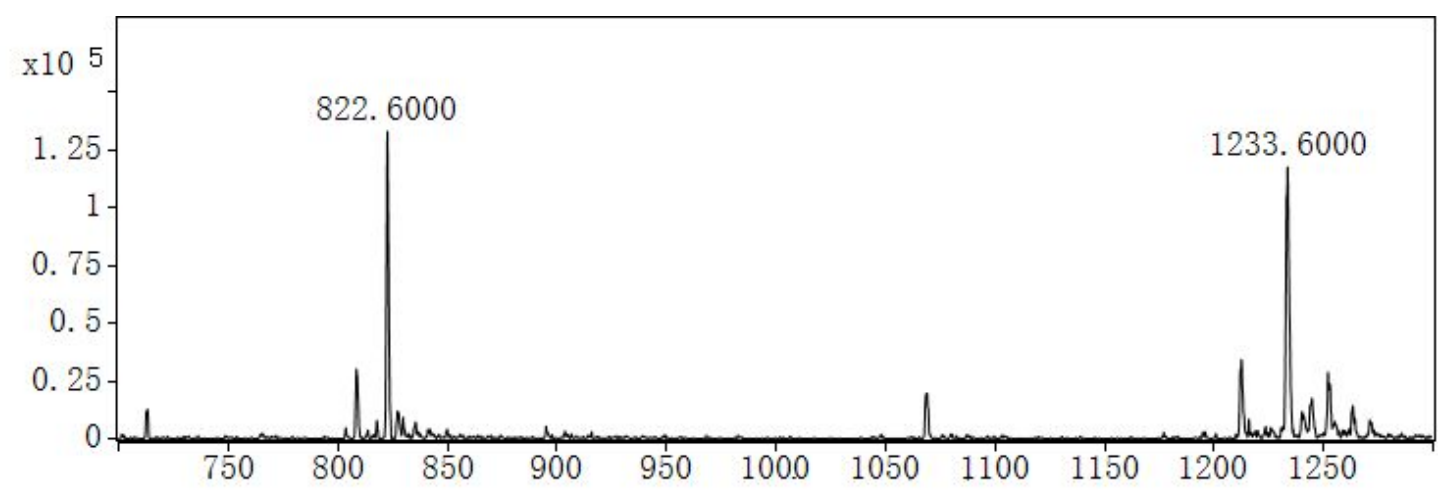

Figure S16. Mass spectrum for compound HYL-21（Ac） 


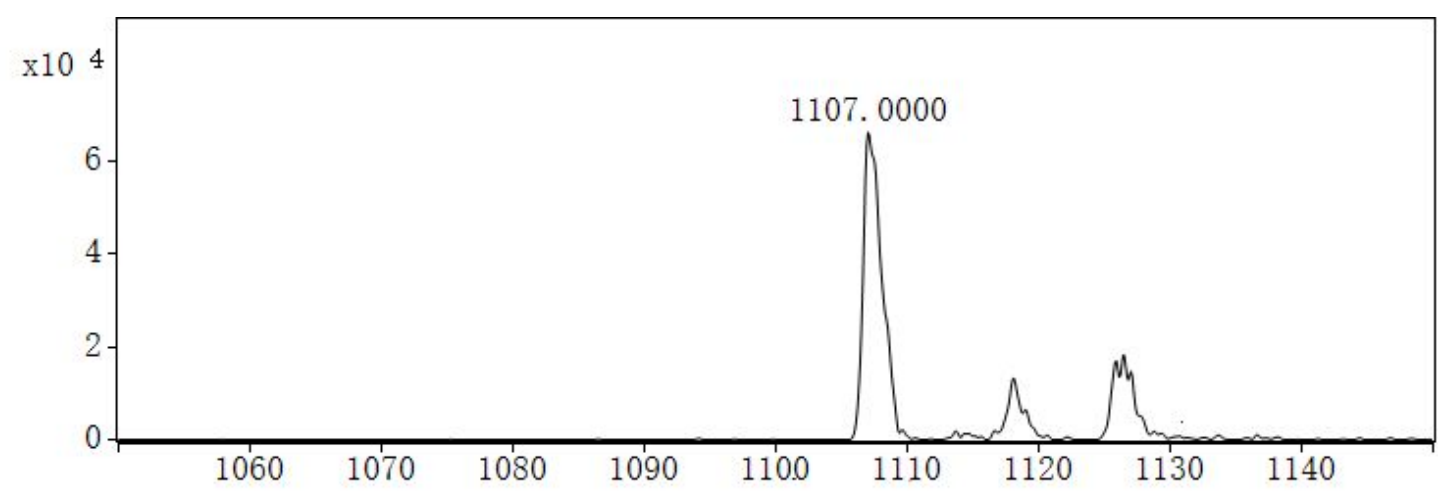

Figure S17. Mass spectrum for compound HYL-21

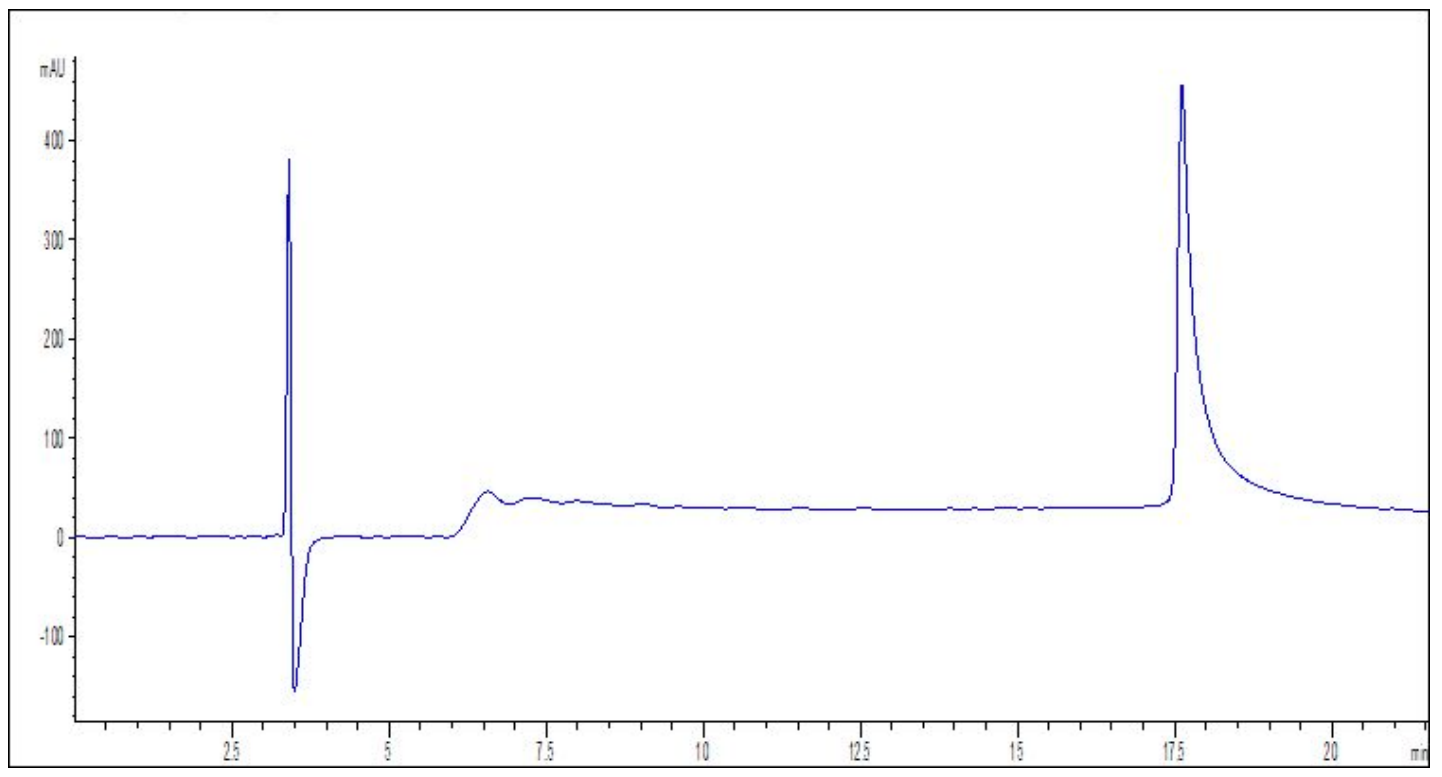

Figure S18. Analytical HPLC trace for compound HYL-22

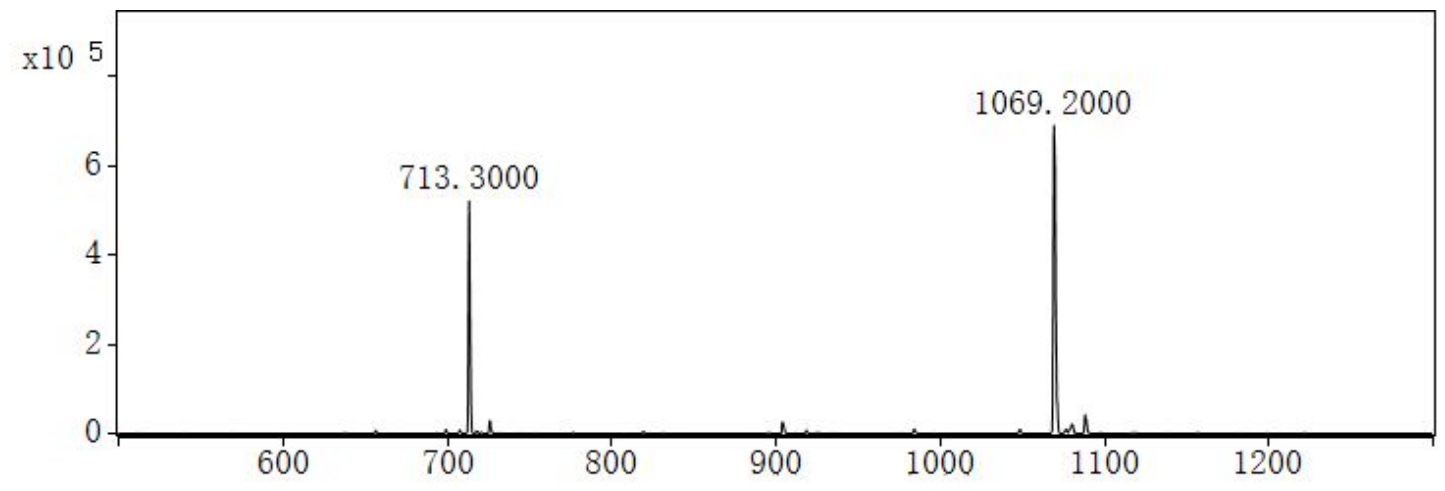

Figure S19. Mass spectrum for compound HYL-22（Ac） 


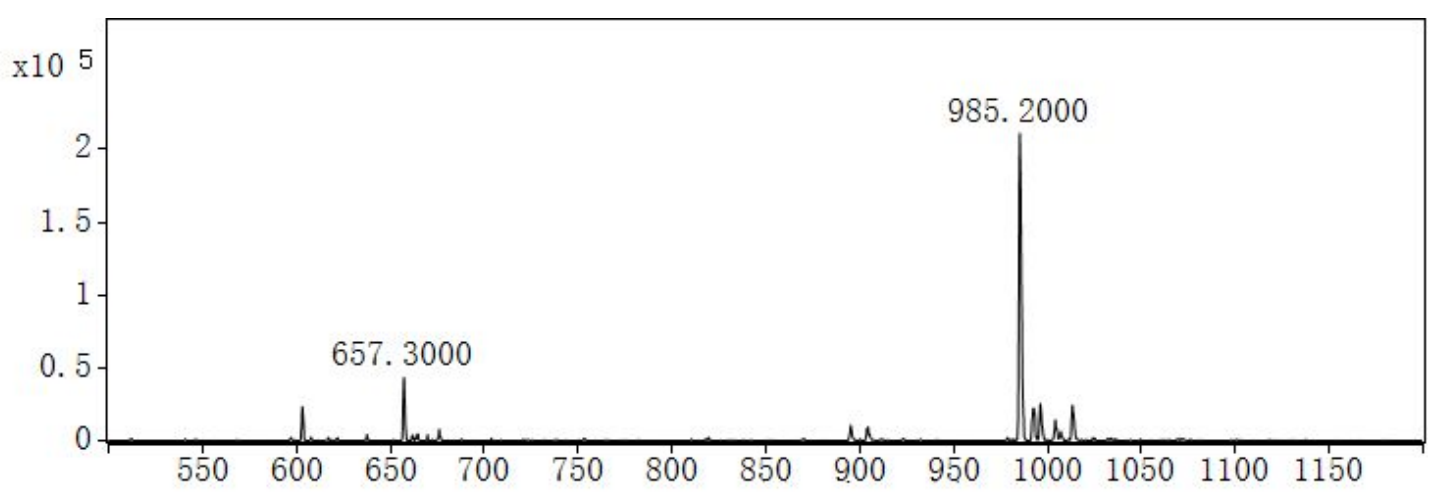

Figure S20. Mass spectrum for compound HYL-22

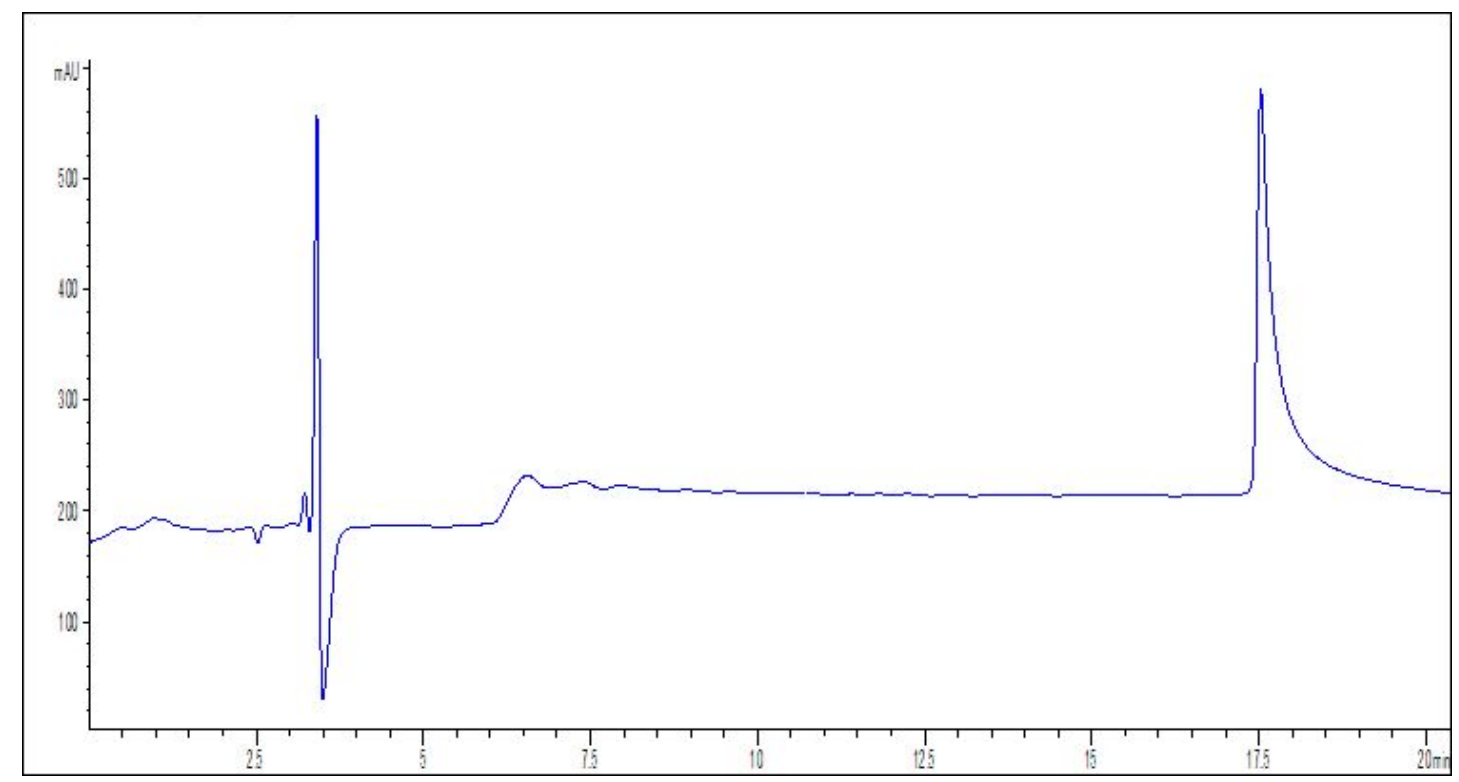

Figure S21. Analytical HPLC trace for compound HYL-23

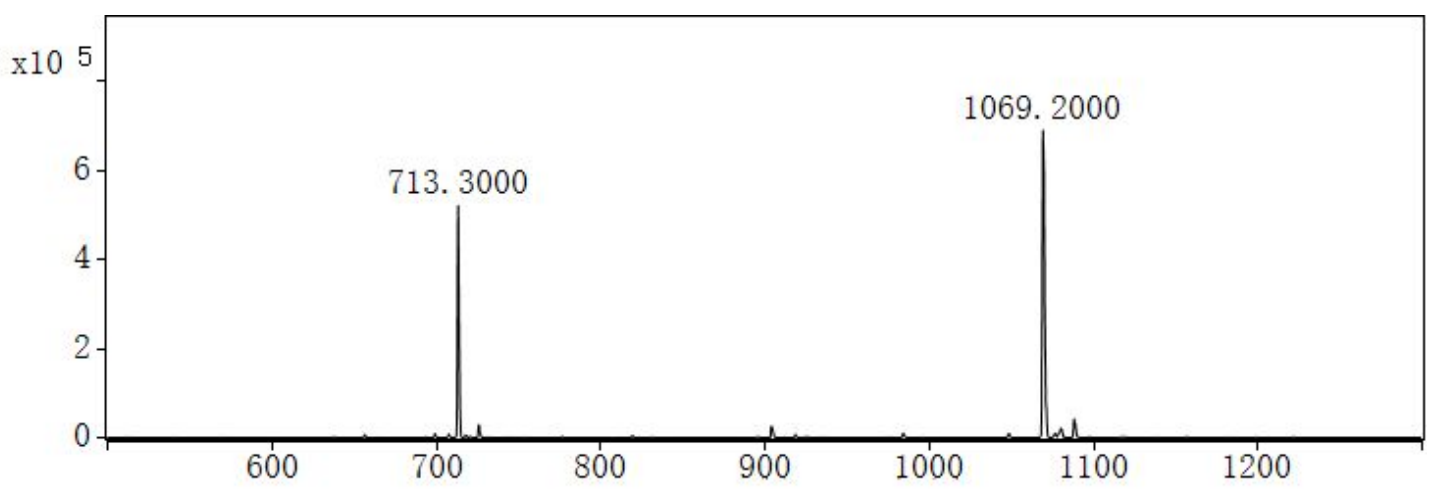

Figure S22. Mass spectrum for compound HYL-23（Ac） 


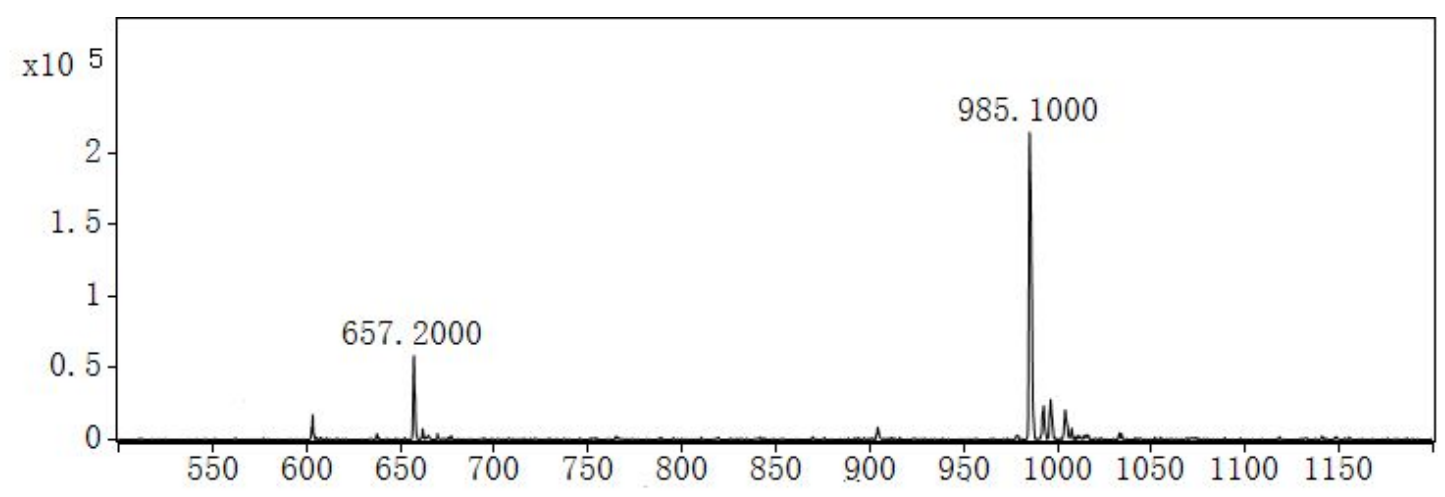

Figure S23. Mass spectrum for compound HYL-23

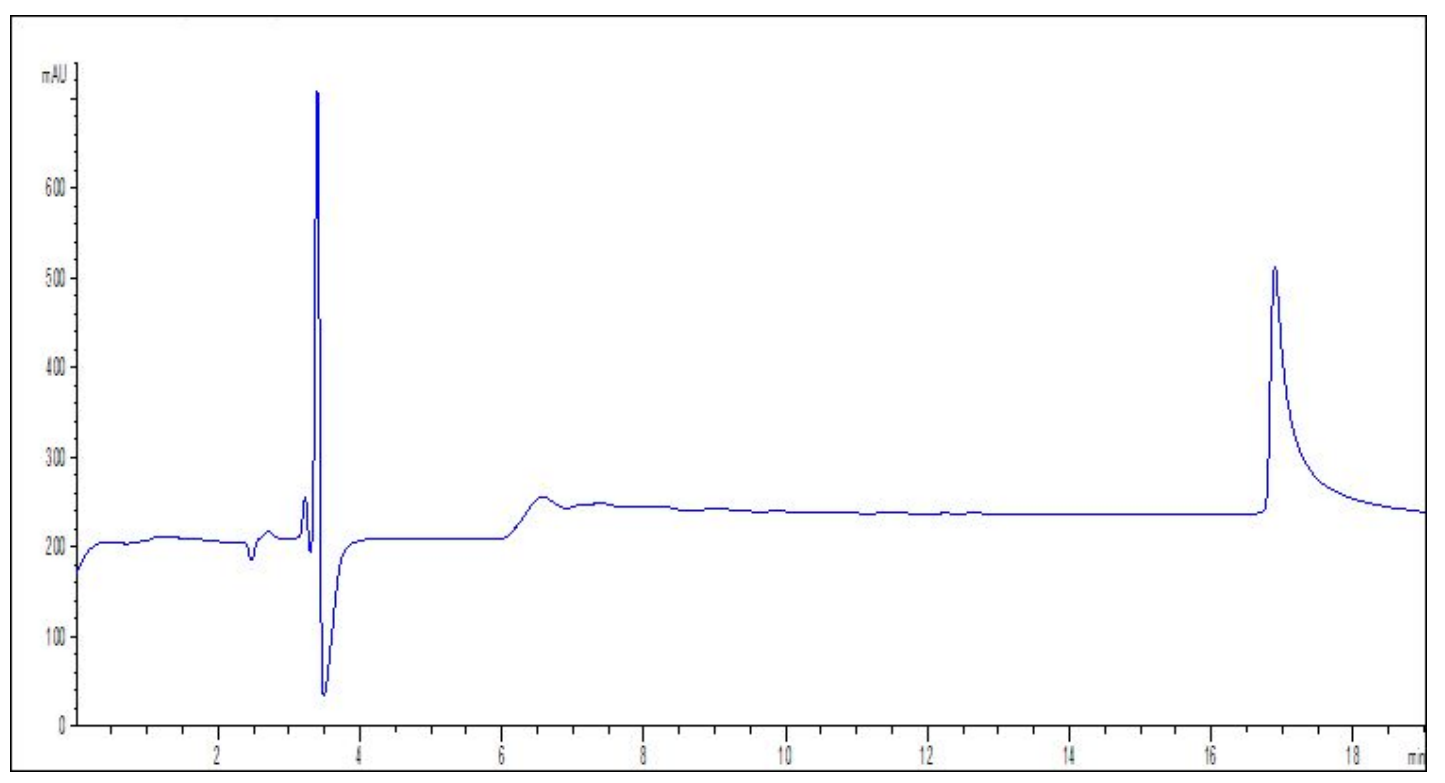

Figure S24. Analytical HPLC trace for compound HYL-24

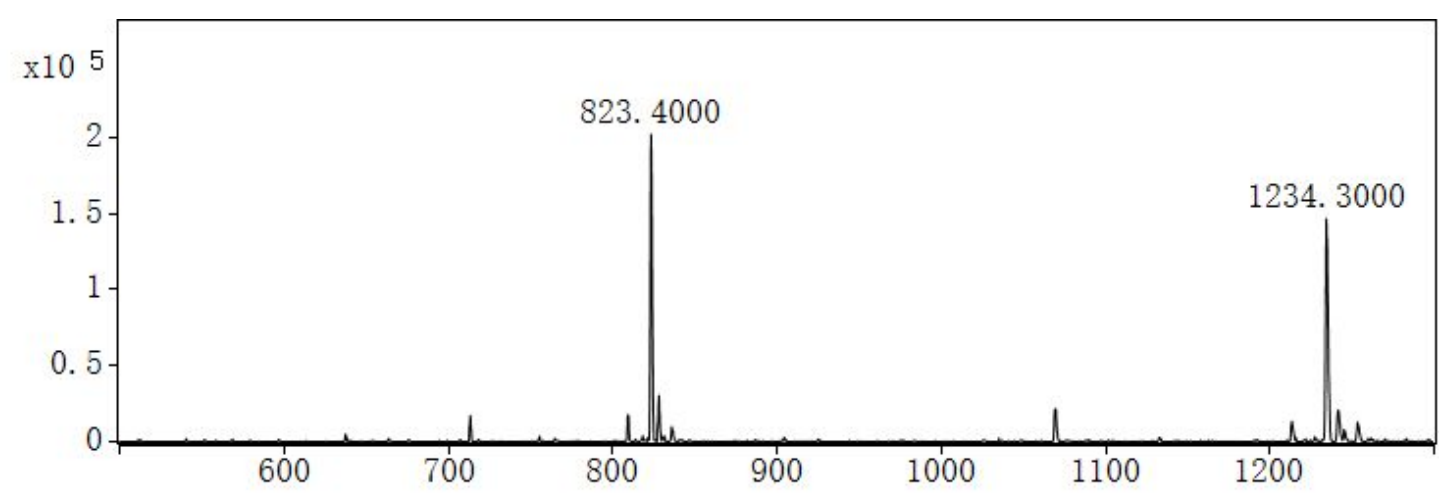

Figure S25. Mass spectrum for compound HYL-24（Ac） 


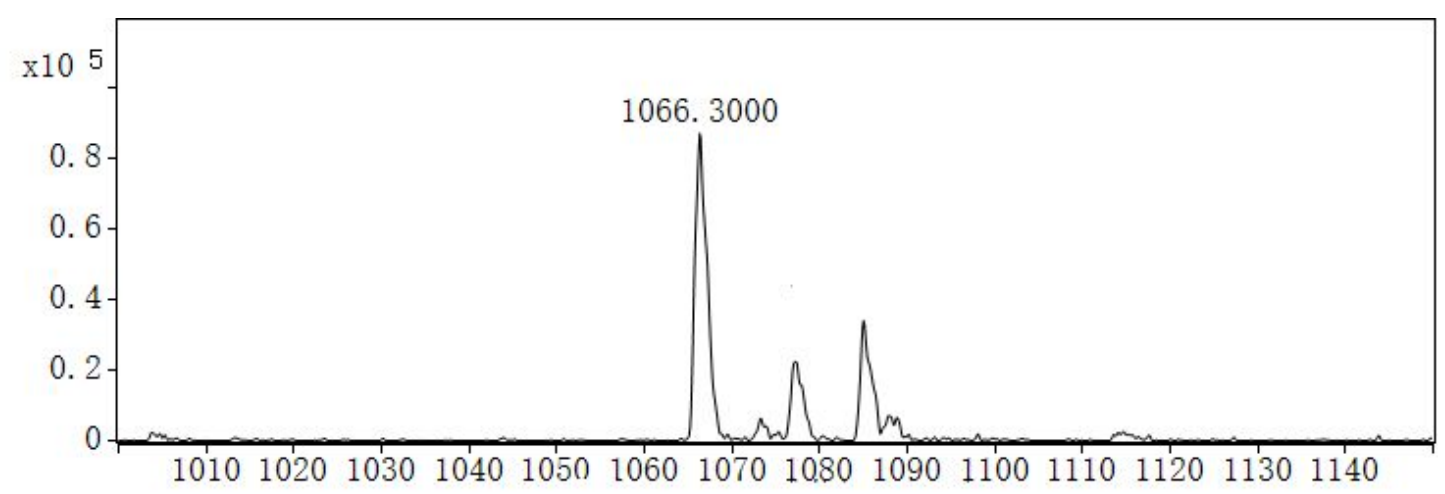

Figure S26. Mass spectrum for compound HYL-24

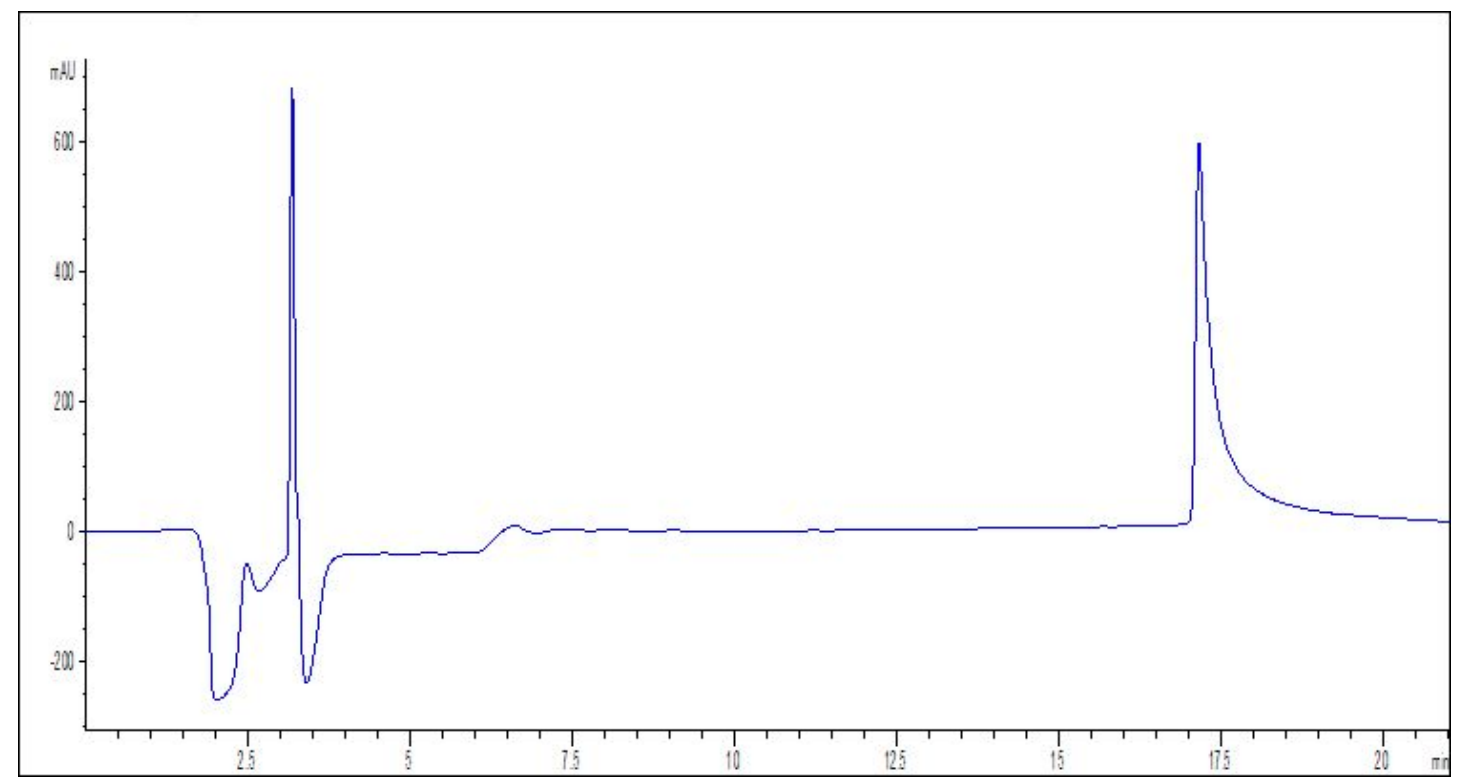

Figure S27. Analytical HPLC trace for compound HYL-25

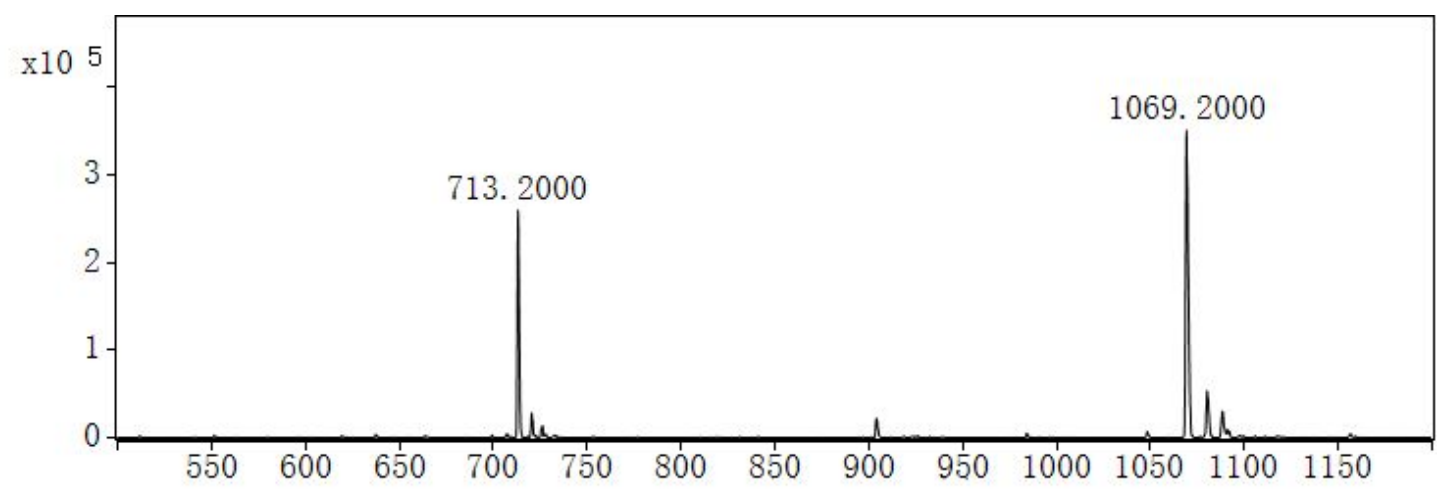

Figure S28. Mass spectrum for compound HYL-25（Ac） 


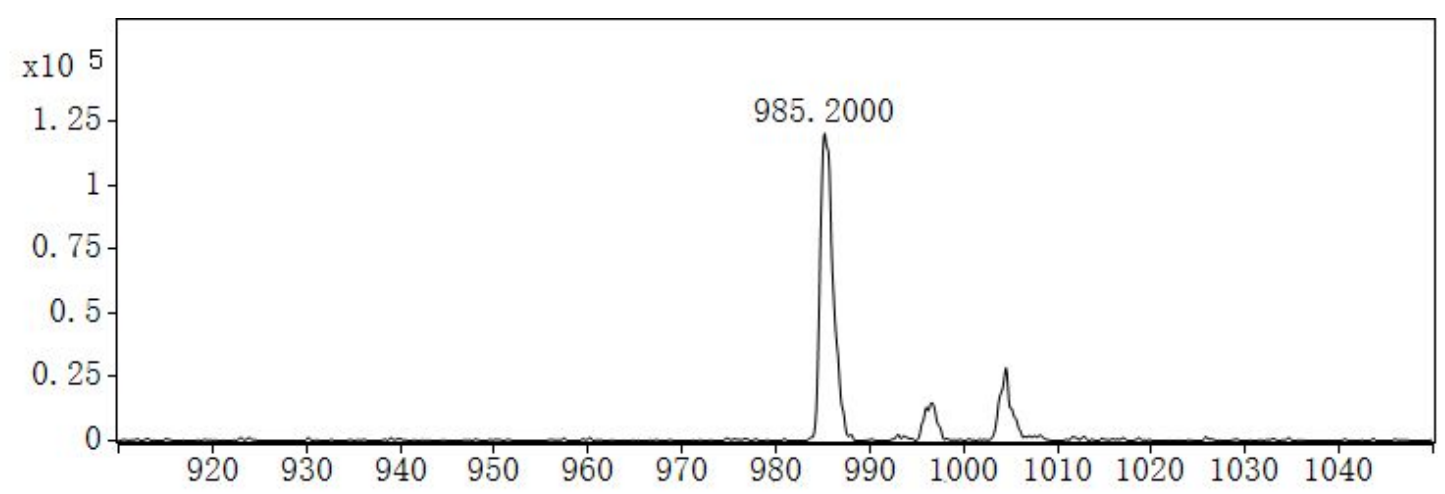

Figure S29. Mass spectrum for compound HYL-25

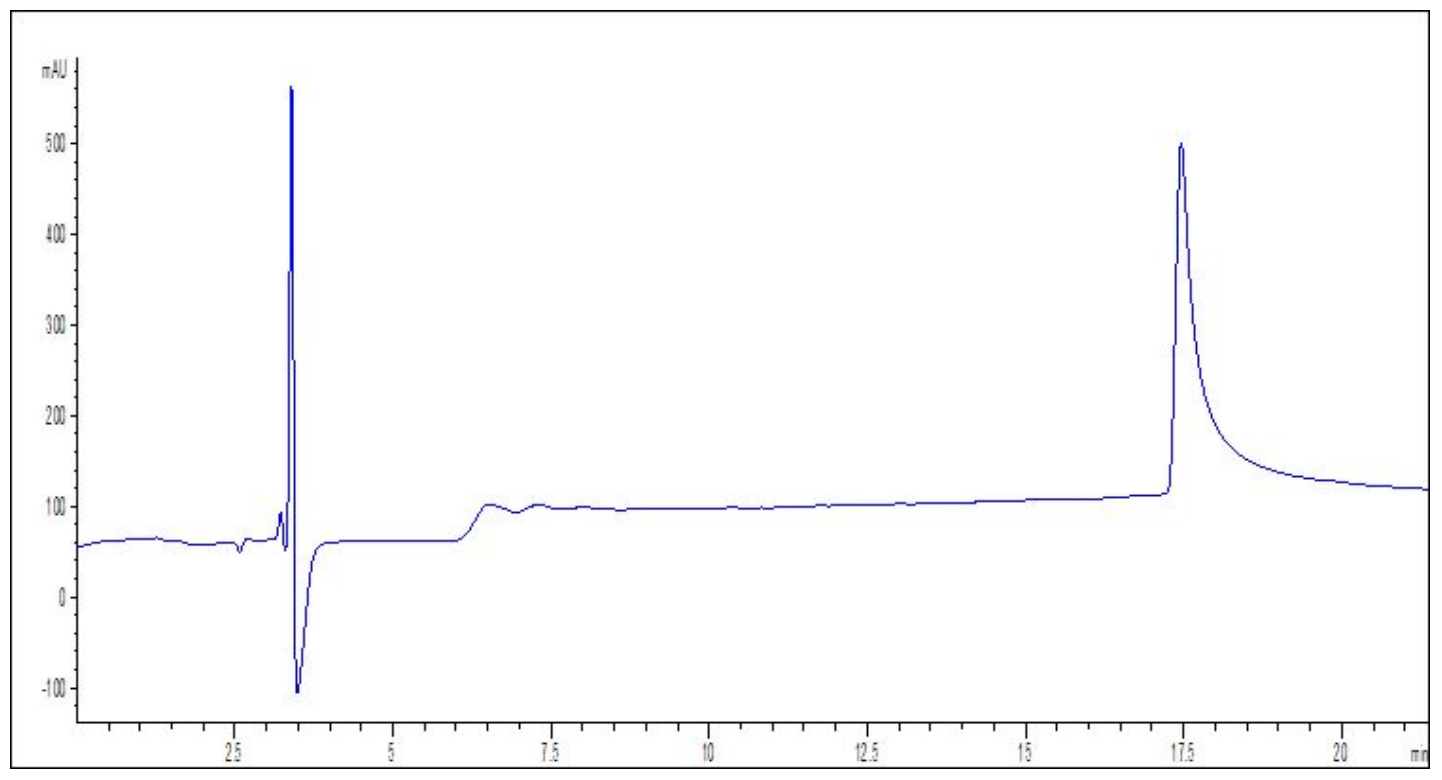

Figure S30. Analytical HPLC trace for compound HYL-26

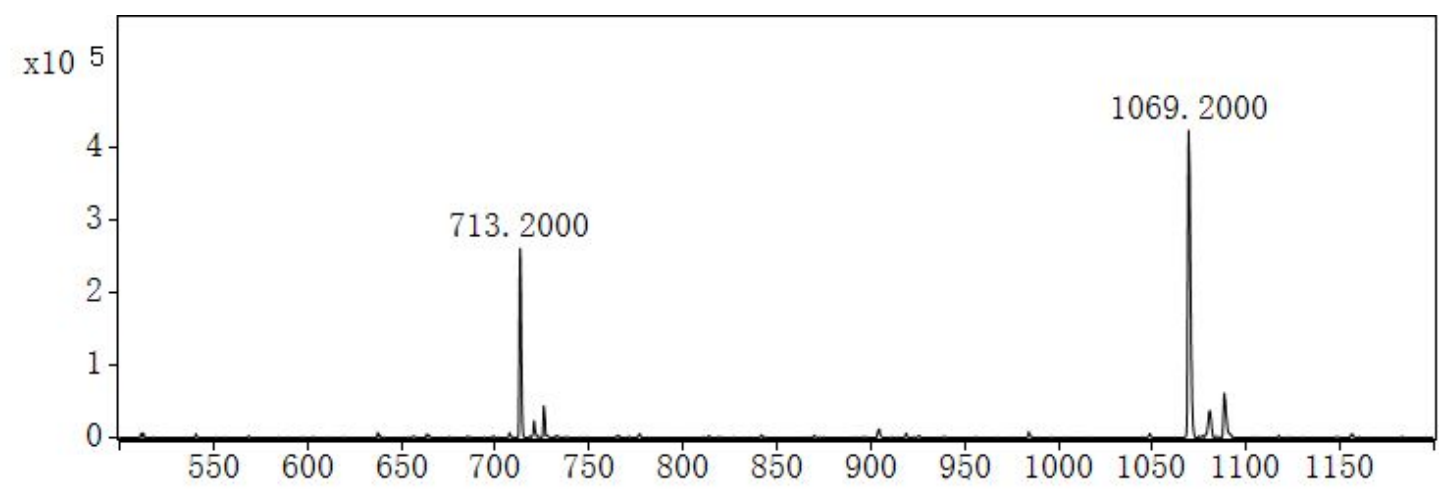

Figure S31. Mass spectrum for compound HYL-26 (Ac) 


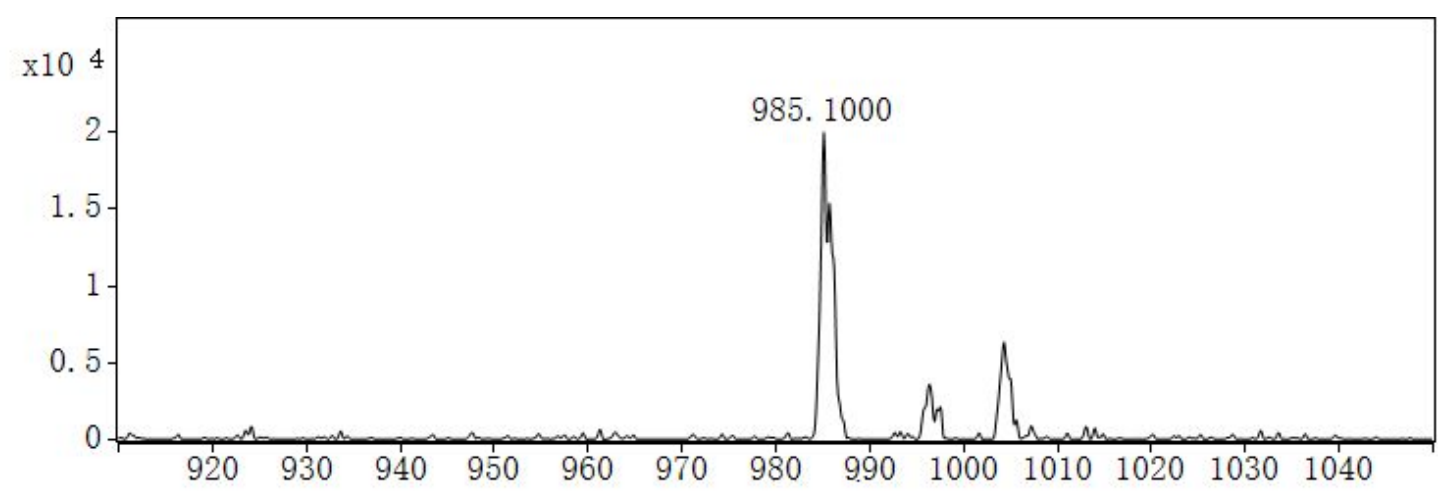

Figure S32. Mass spectrum for compound HYL-26

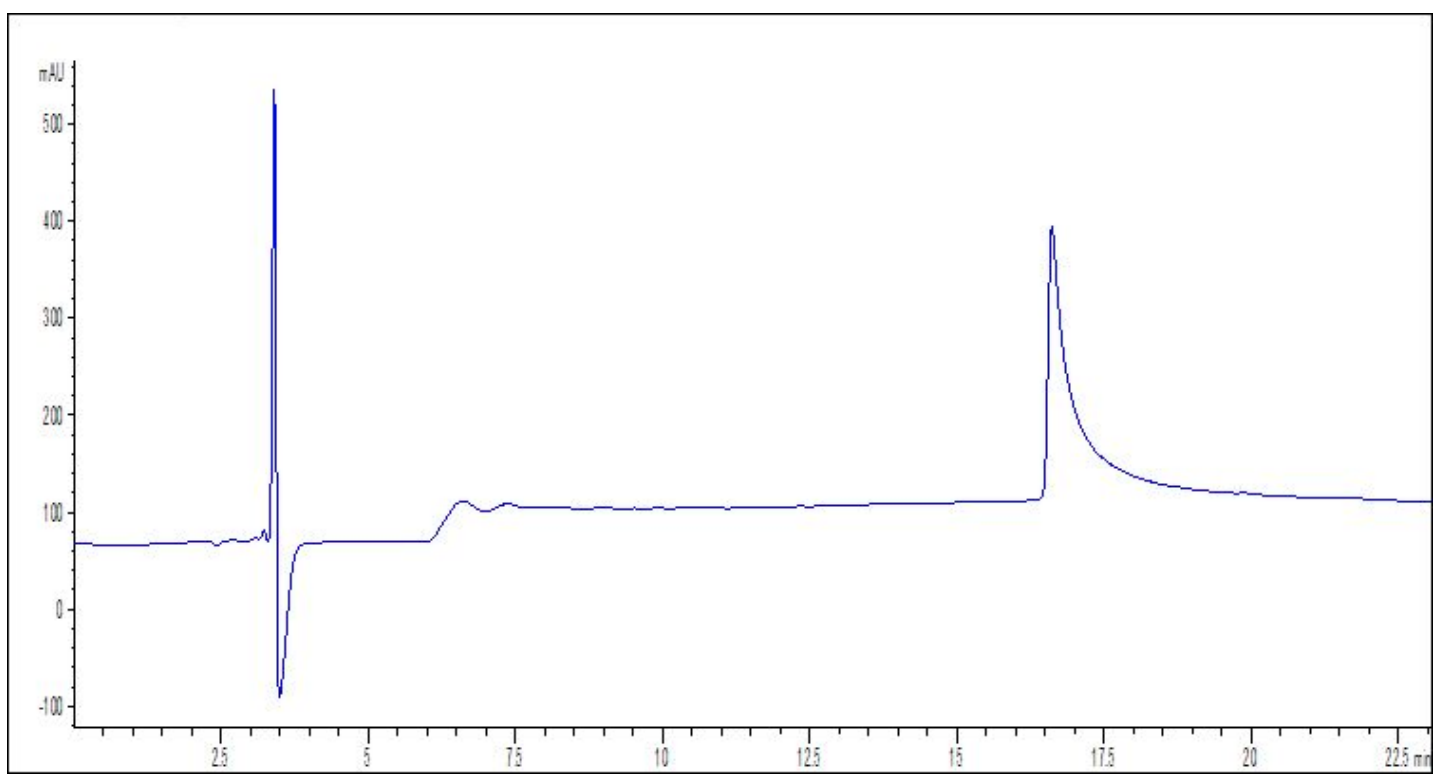

Figure S33. Analytical HPLC trace for compound HYL-27

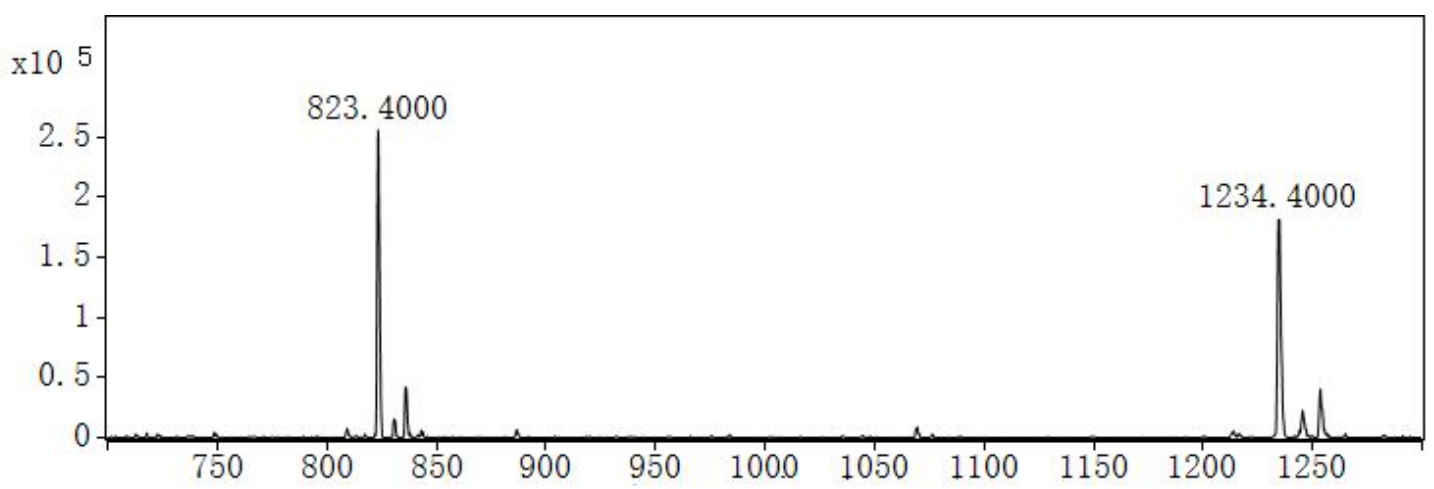

Figure S34. Mass spectrum for compound HYL-27（Ac） 


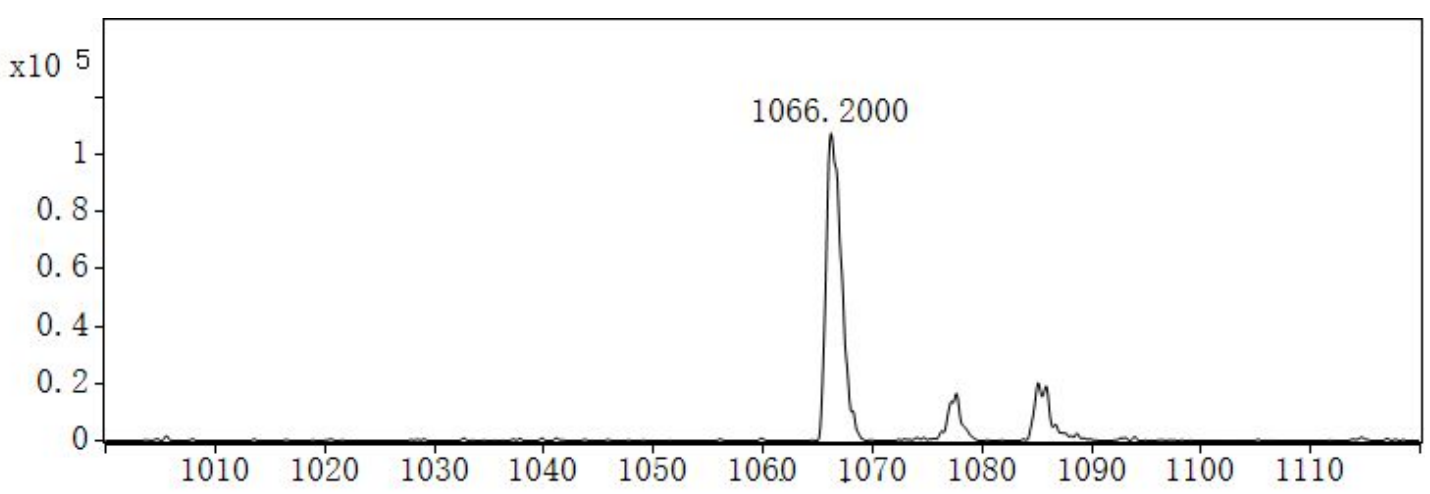

Figure S35. Mass spectrum for compound HYL-27

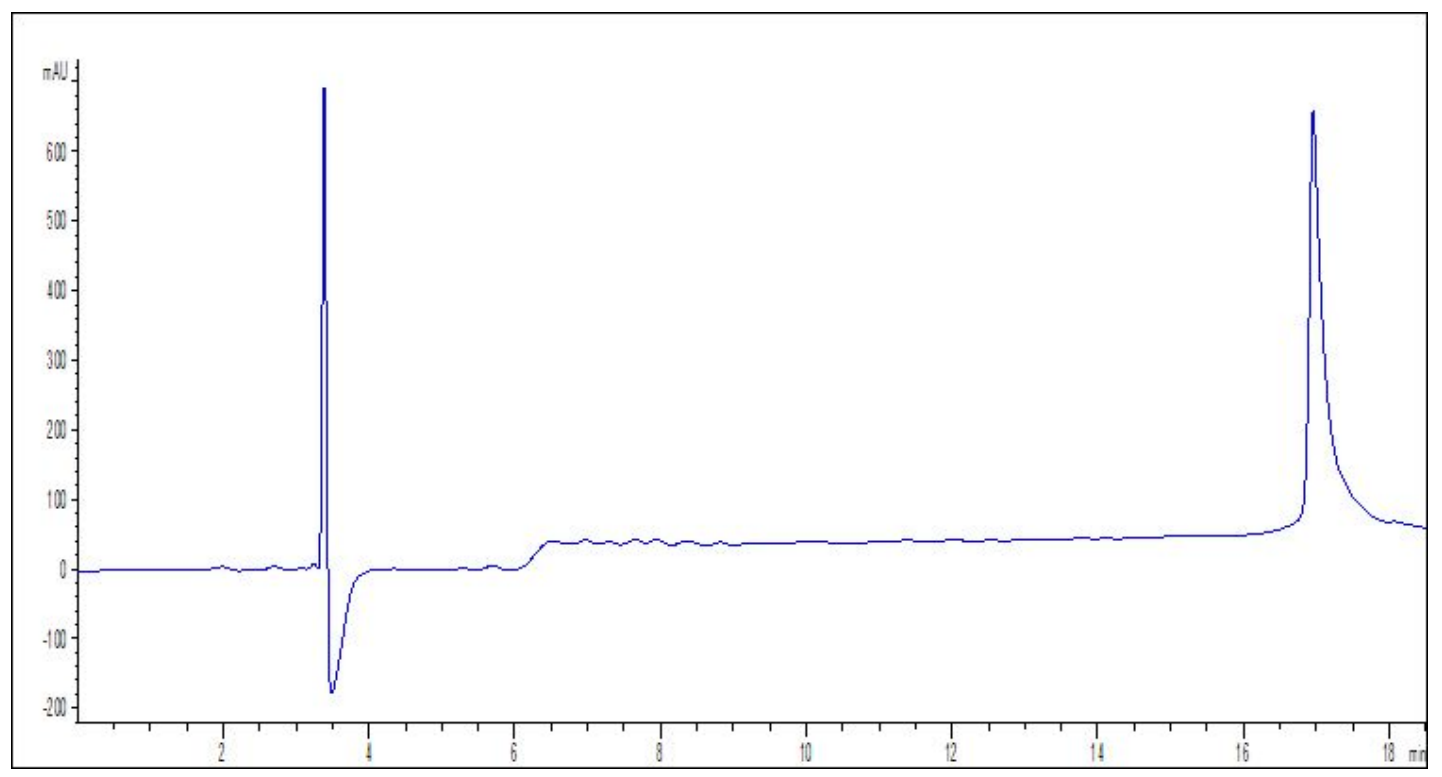

Figure S36. Analytical HPLC trace for compound HYL-28

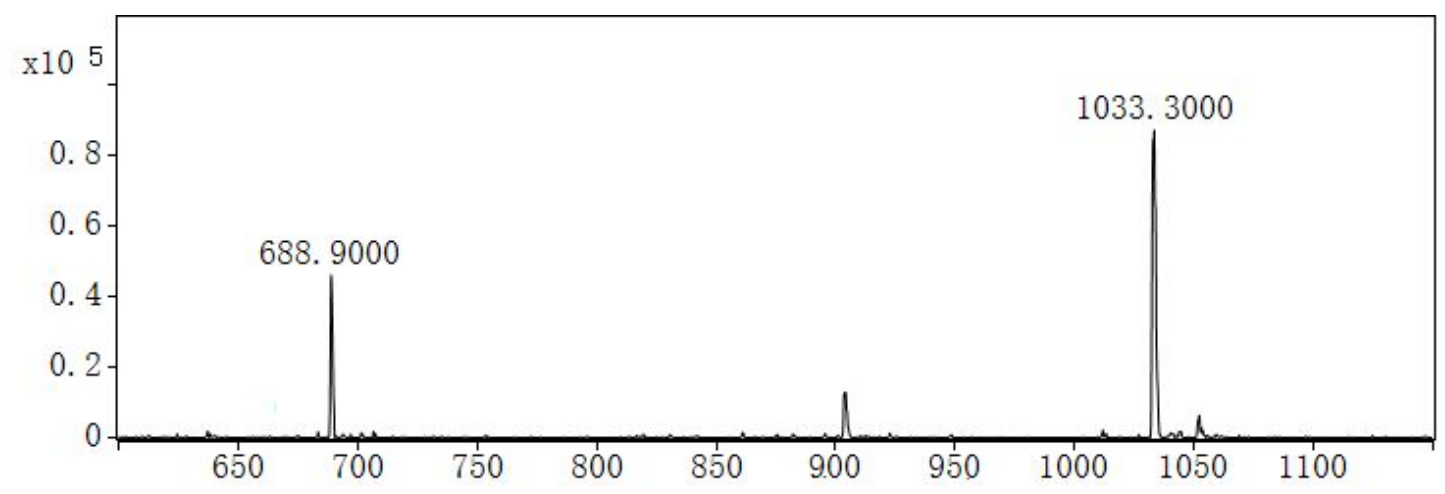

Figure S37. Mass spectrum for compound HYL-28 (Ac) 


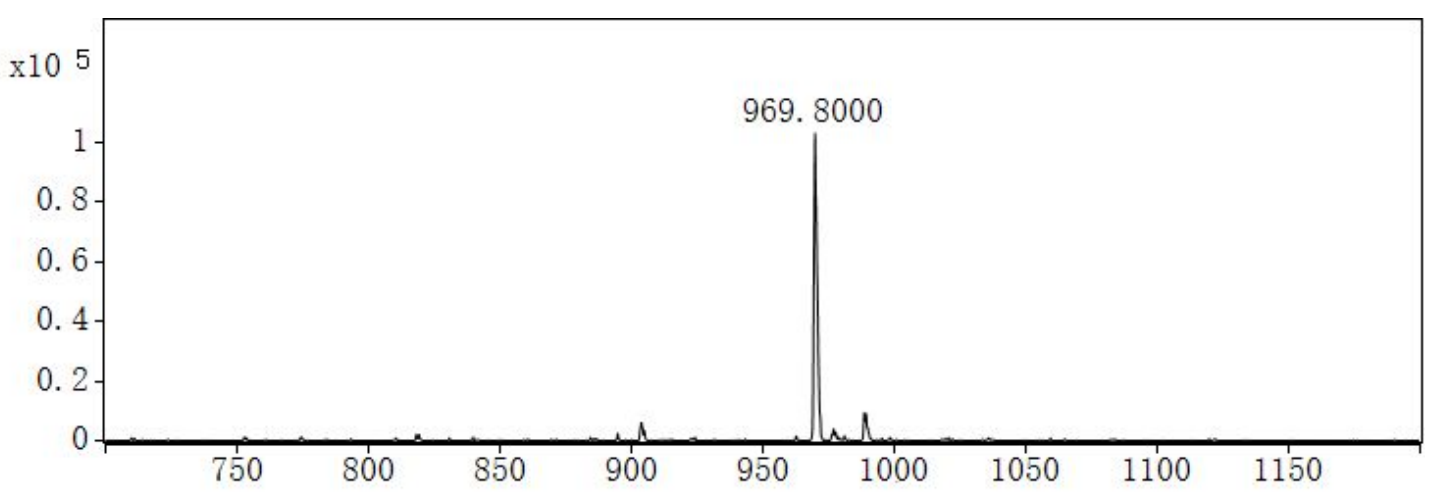

Figure S38. Mass spectrum for compound HYL-28

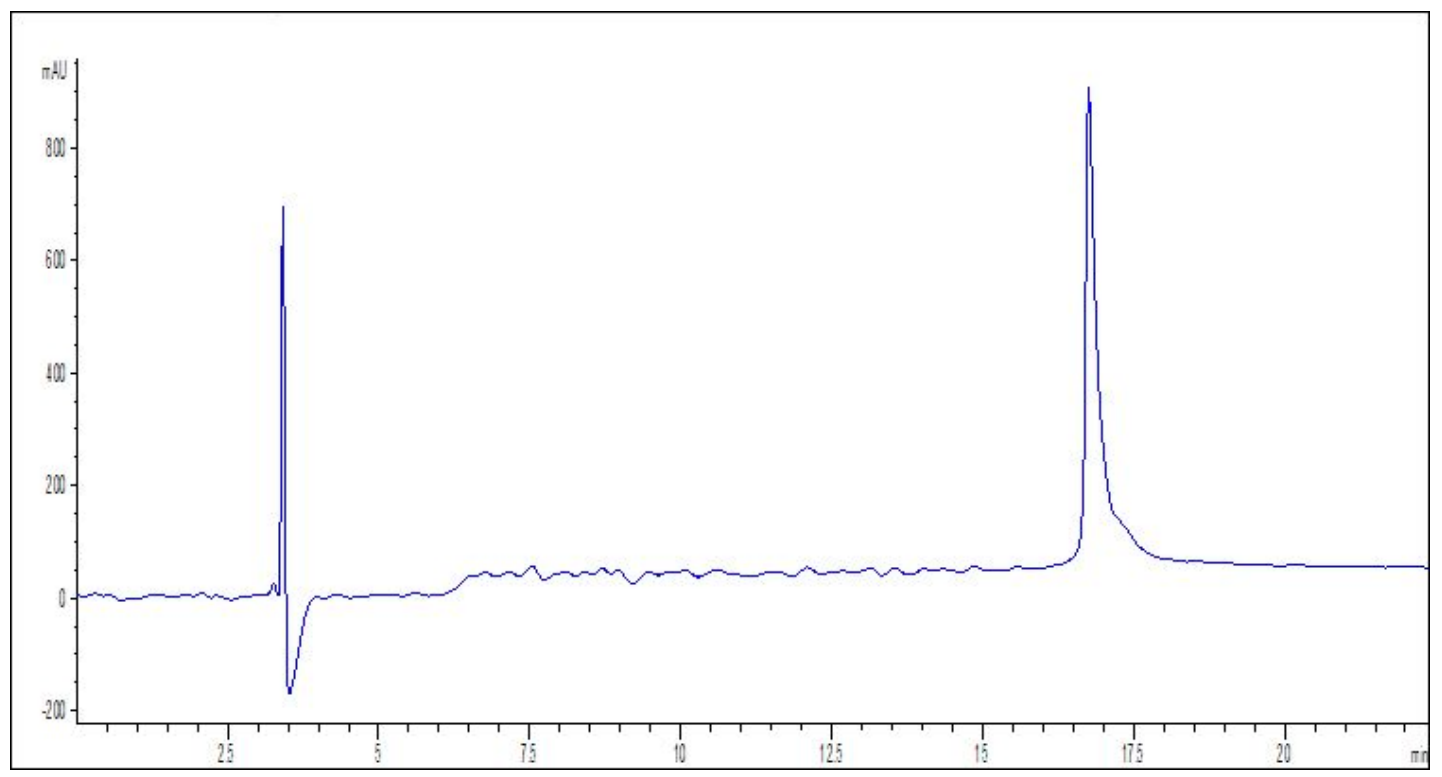

Figure S39. Analytical HPLC trace for compound HYL-29

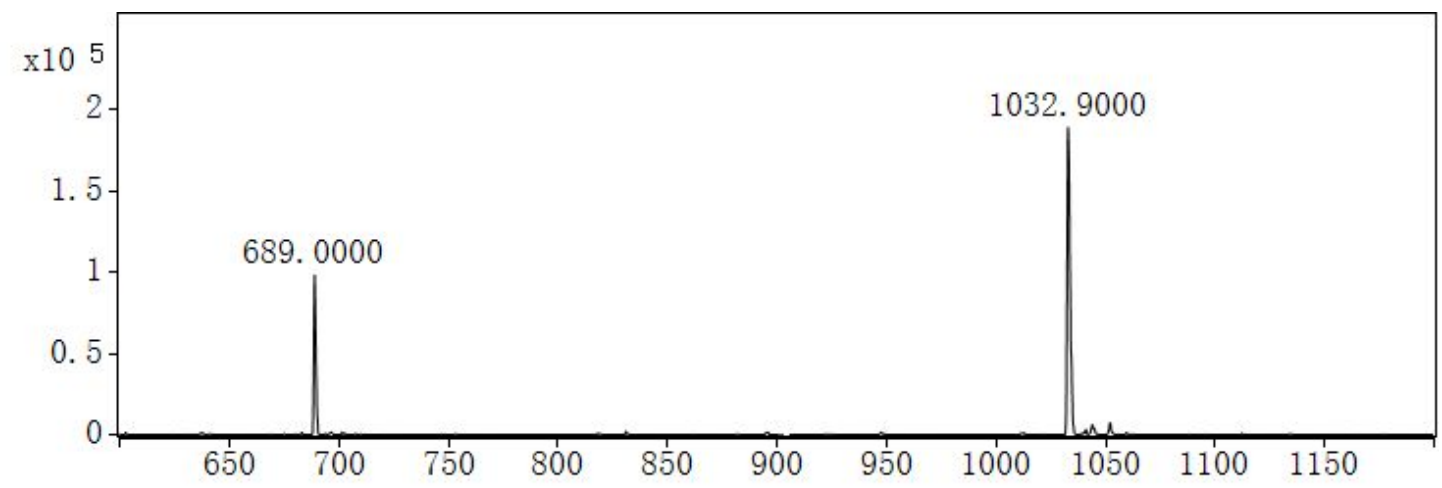

Figure S40. Mass spectrum for compound HYL-29（Ac） 


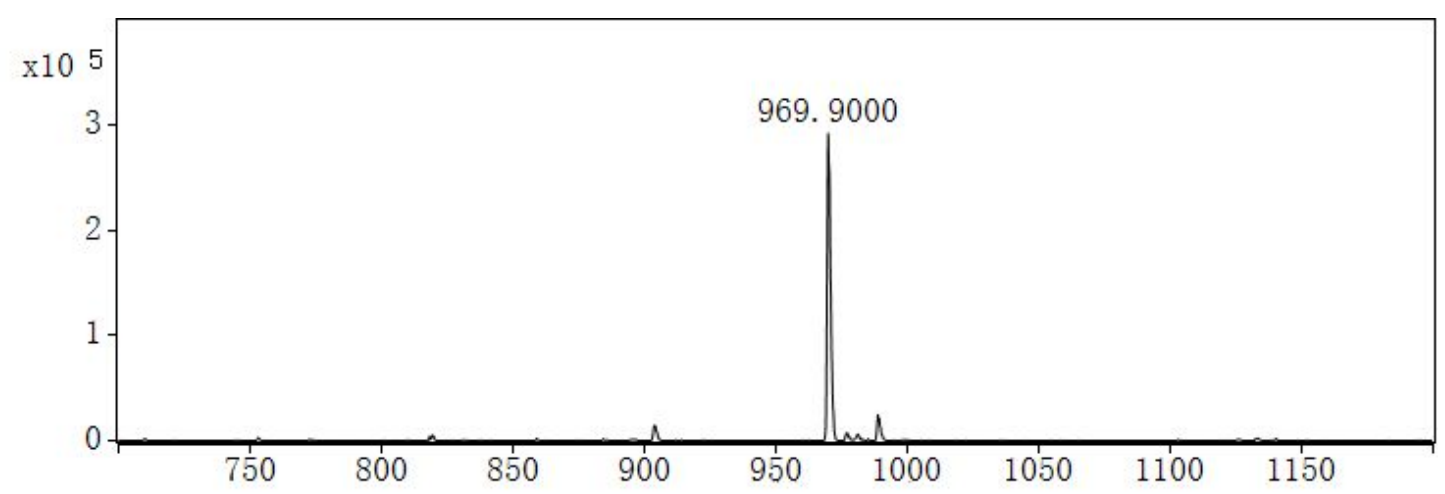

Figure S41. Mass spectrum for compound HYL-29

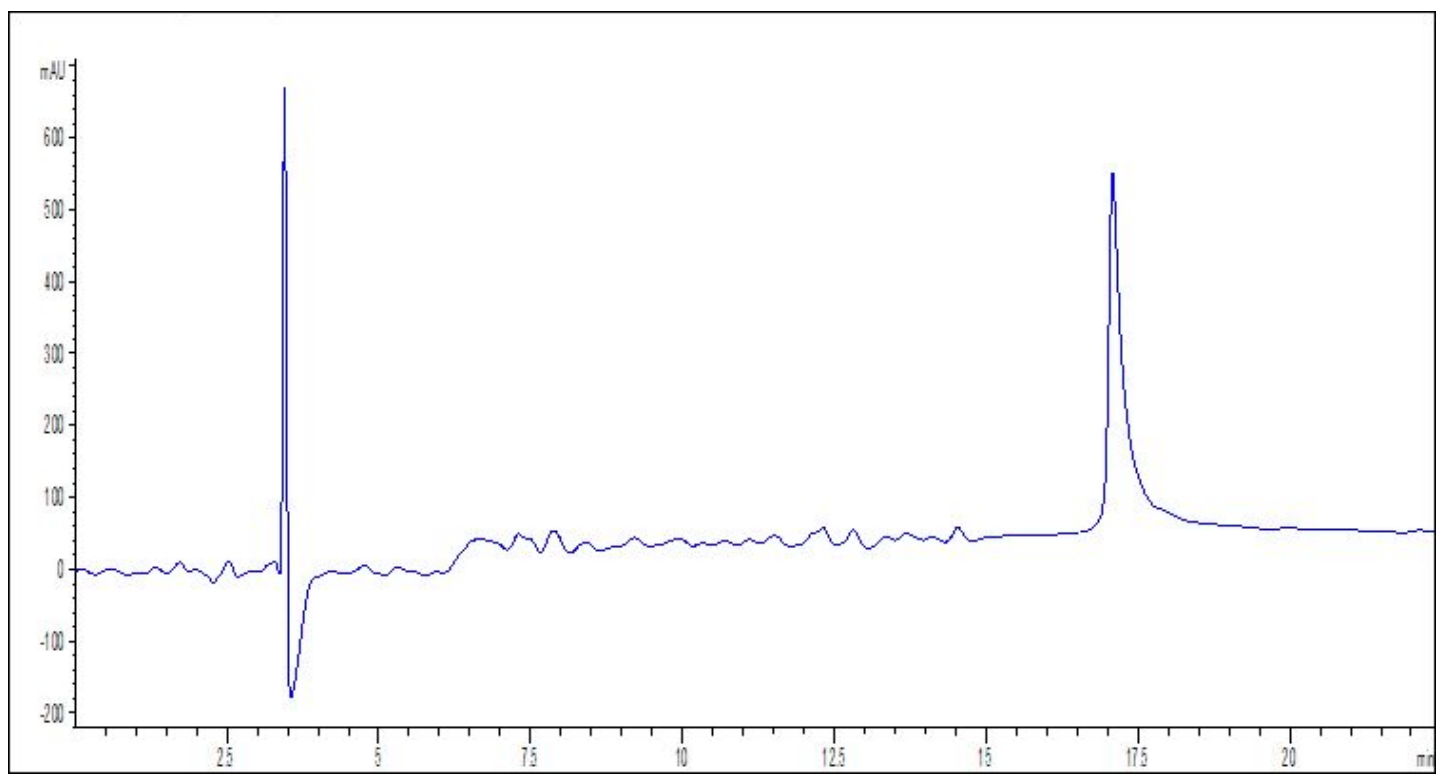

Figure S42. Analytical HPLC trace for compound HYL-30

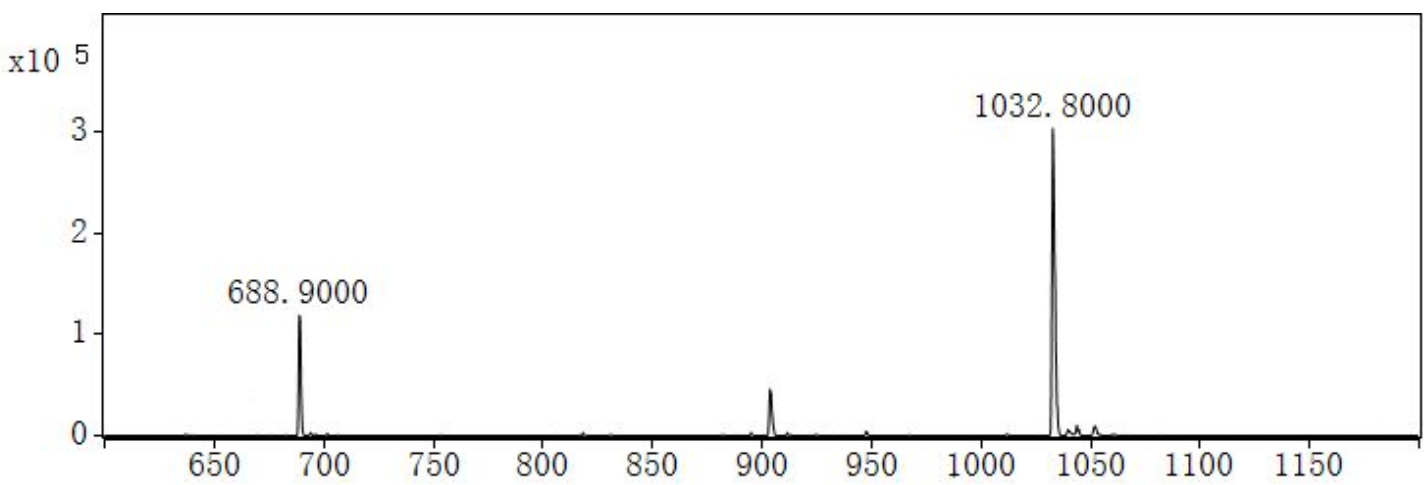

Figure S43. Mass spectrum for compound HYL-30（Ac） 


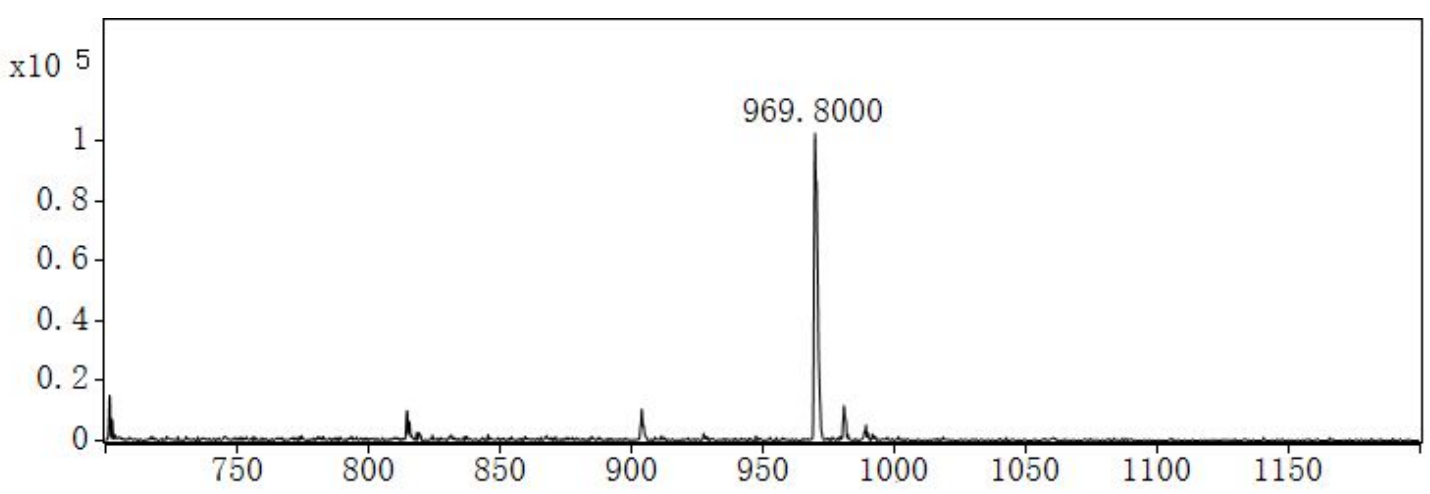

Figure S44. Mass spectrum for compound HYL-30

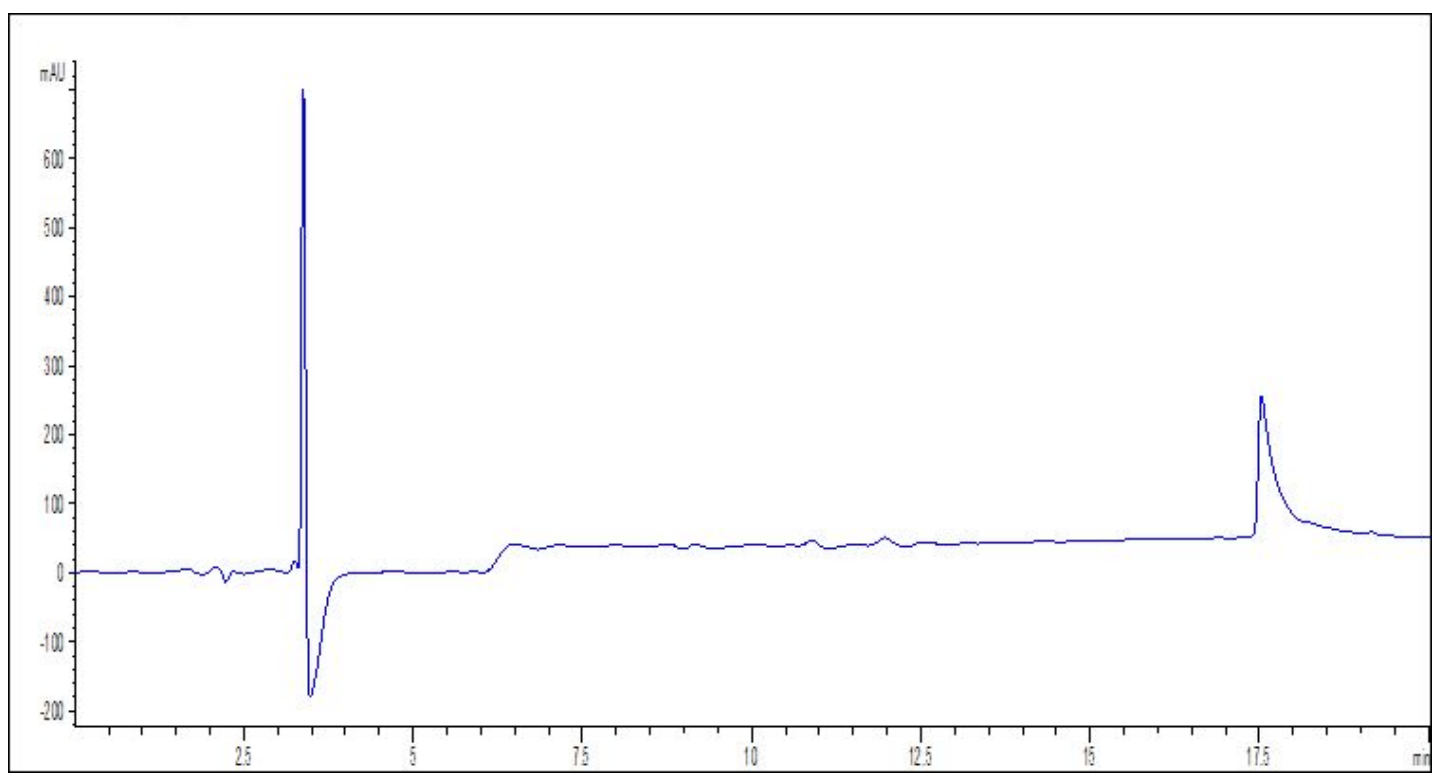

Figure S45. Analytical HPLC trace for compound HYL-31

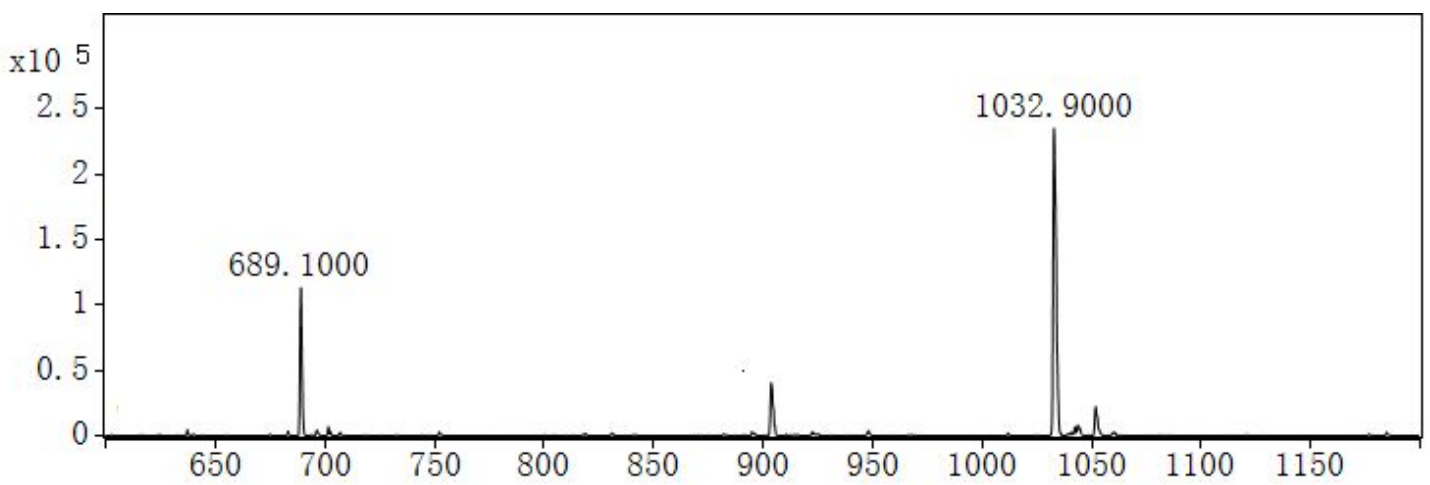

Figure S46. Mass spectrum for compound HYL-31（Ac） 


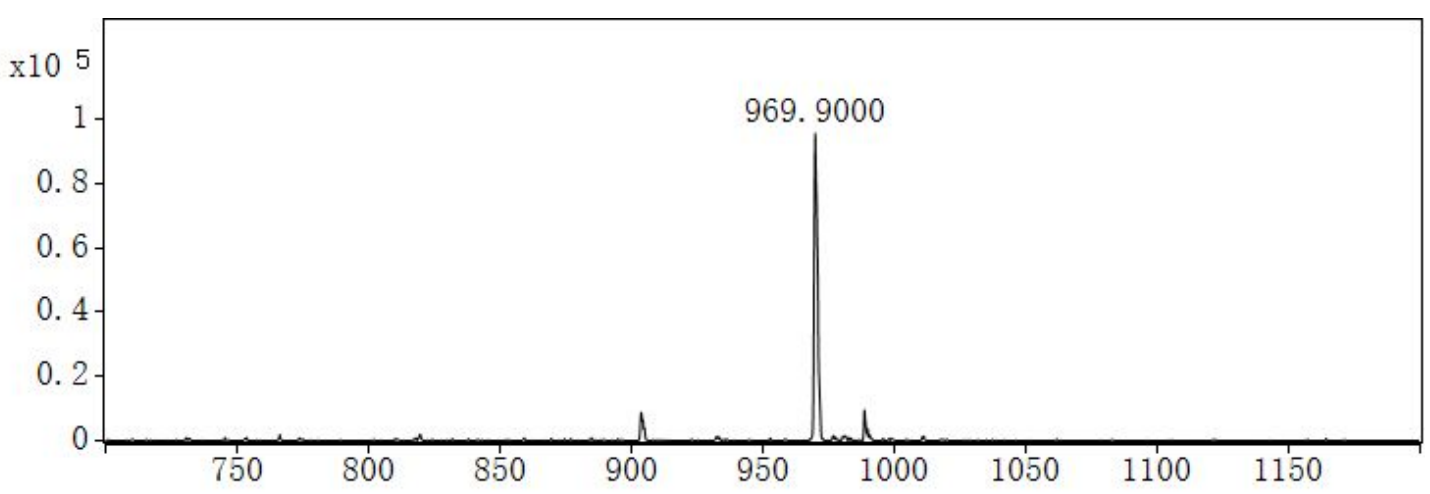

Figure S47. Mass spectrum for compound HYL-31

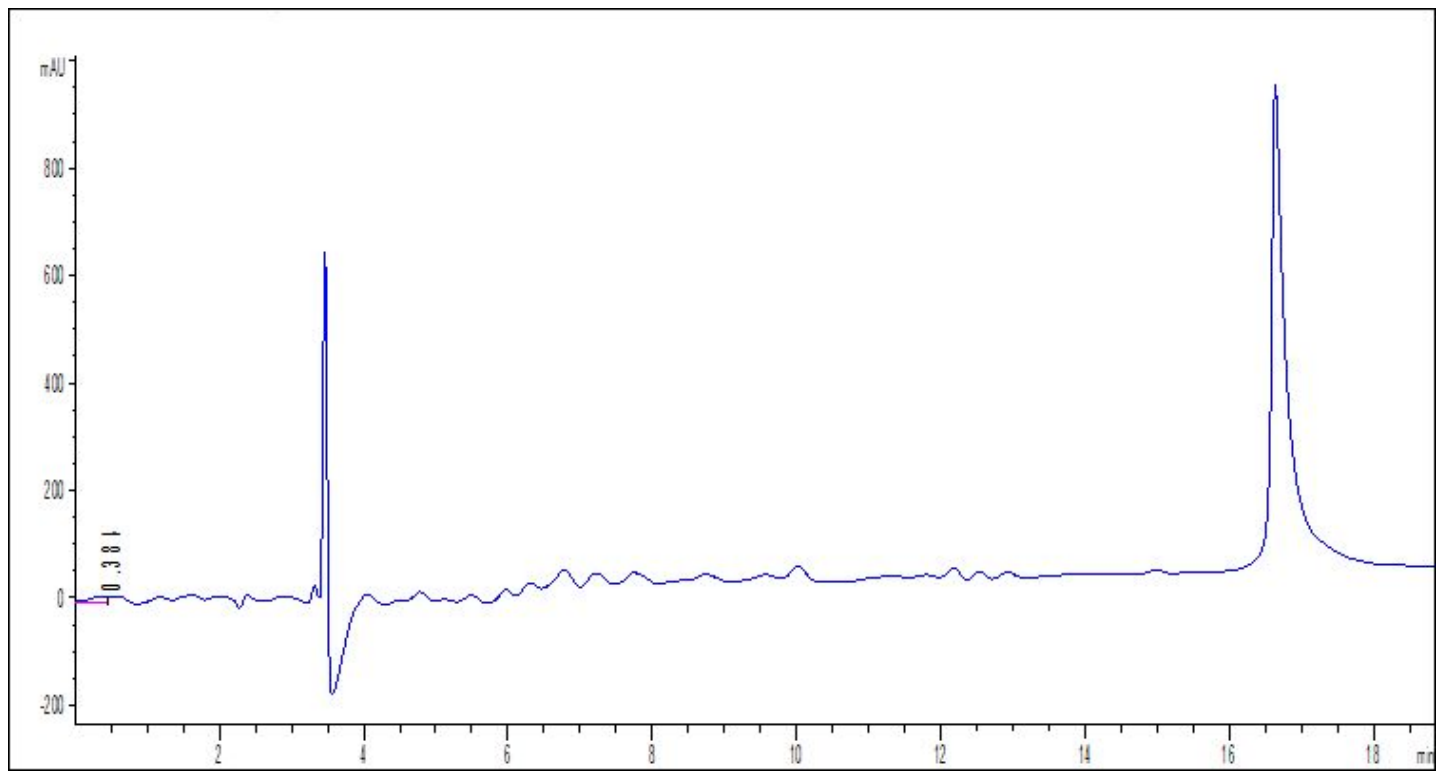

Figure S48. Analytical HPLC trace for compound HYL-32

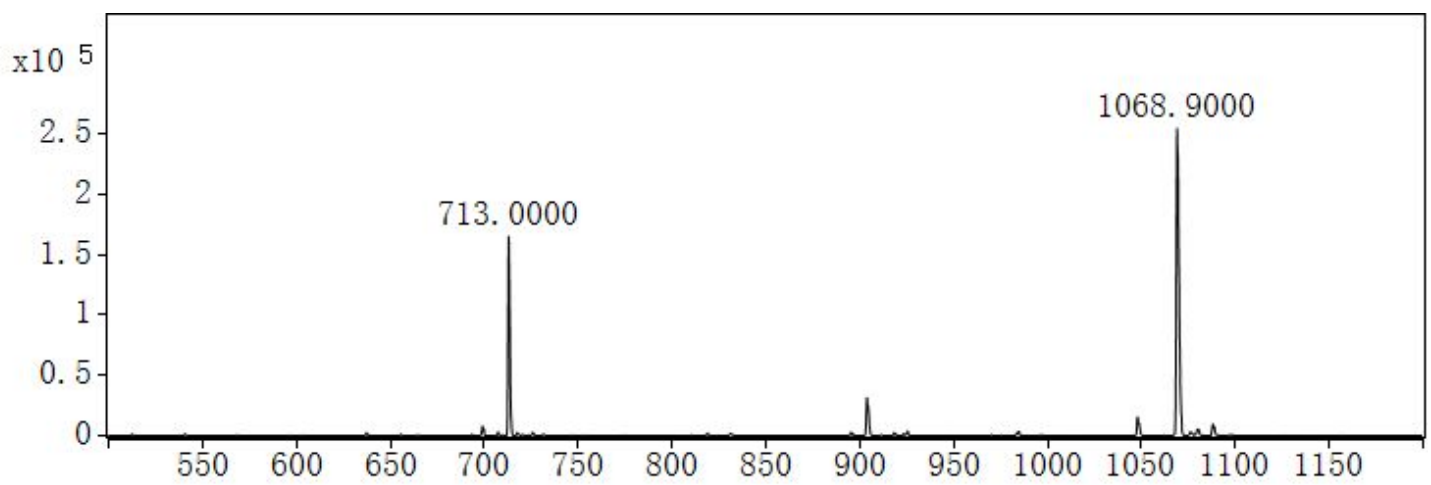

Figure S49. Mass spectrum for compound HYL-32（Ac） 


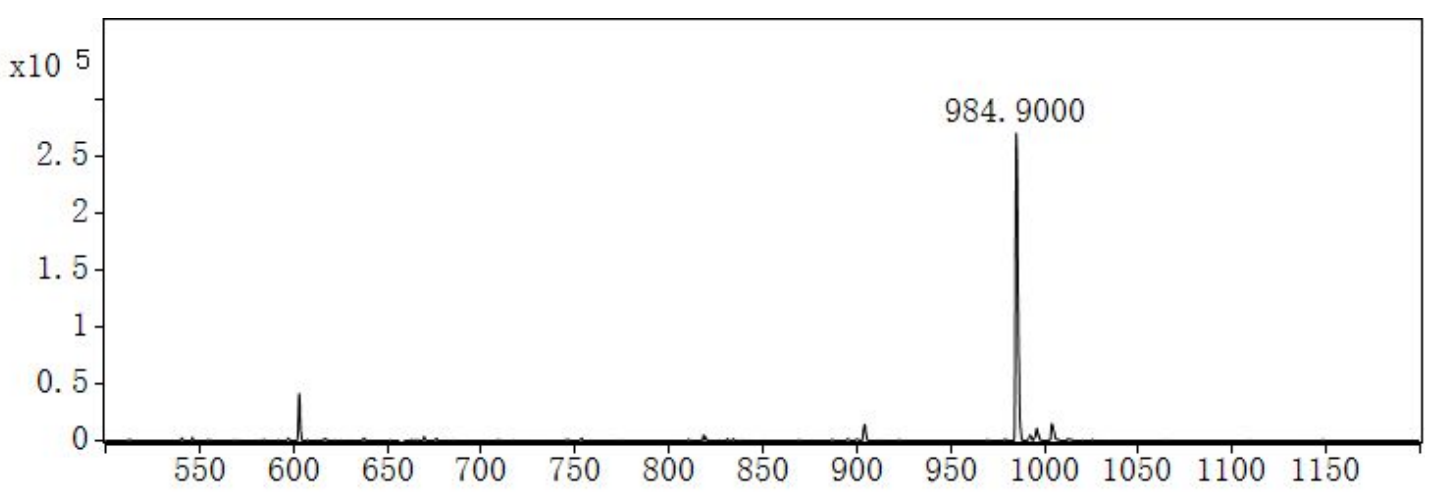

Figure S50. Mass spectrum for compound HYL-32

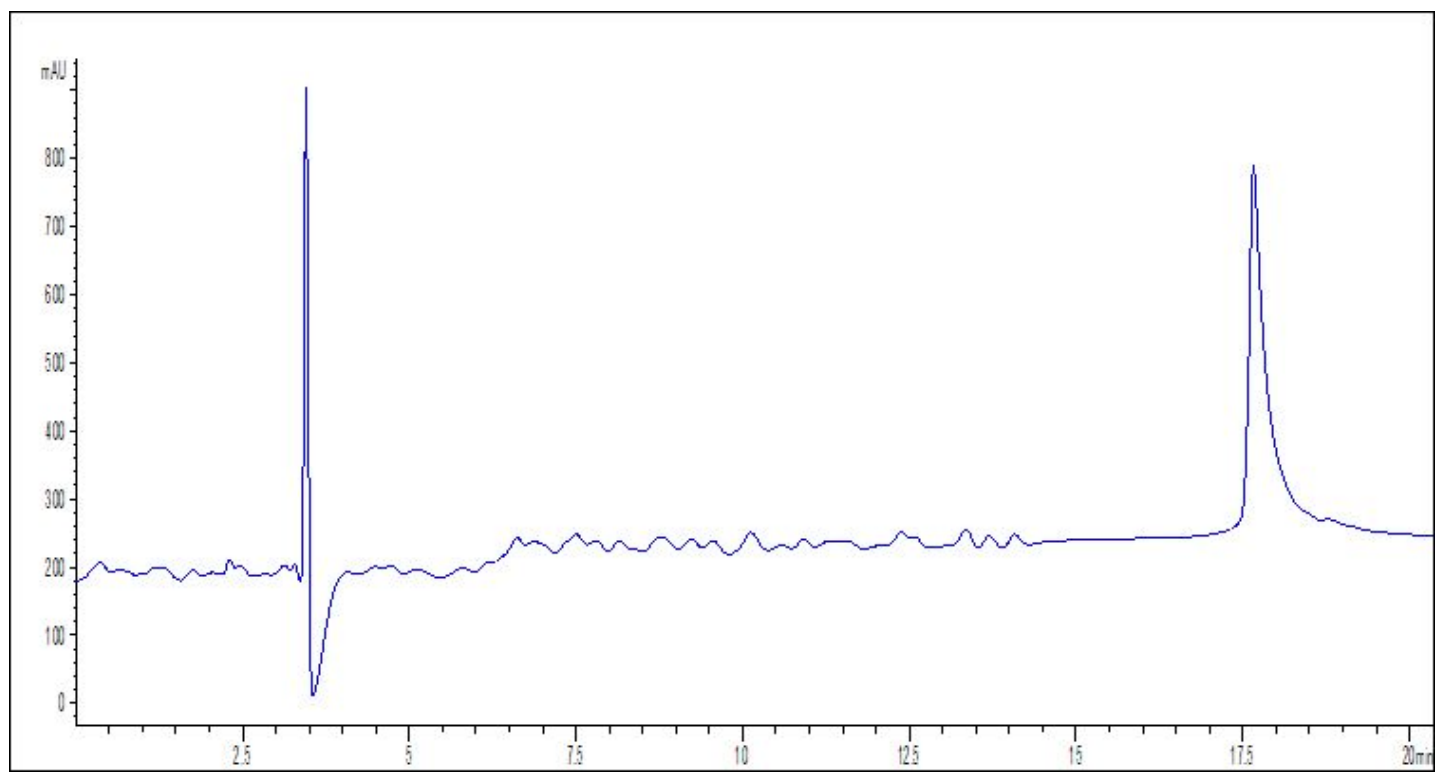

Figure S51. Analytical HPLC trace for compound HYL-33

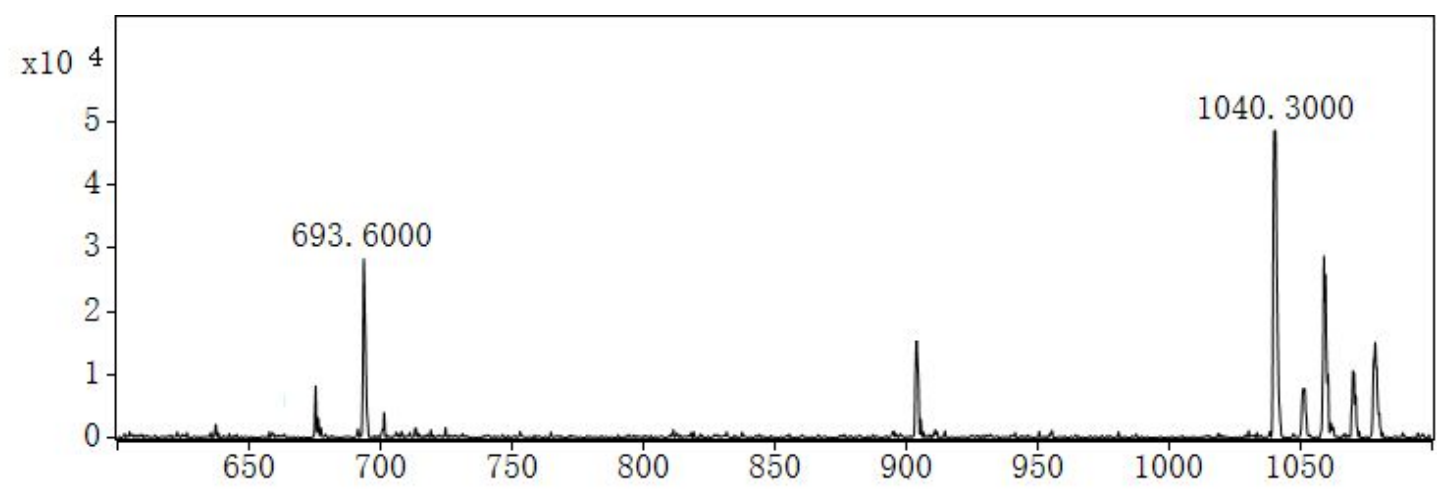

Figure S52. Mass spectrum for compound HYL-33（Ac） 


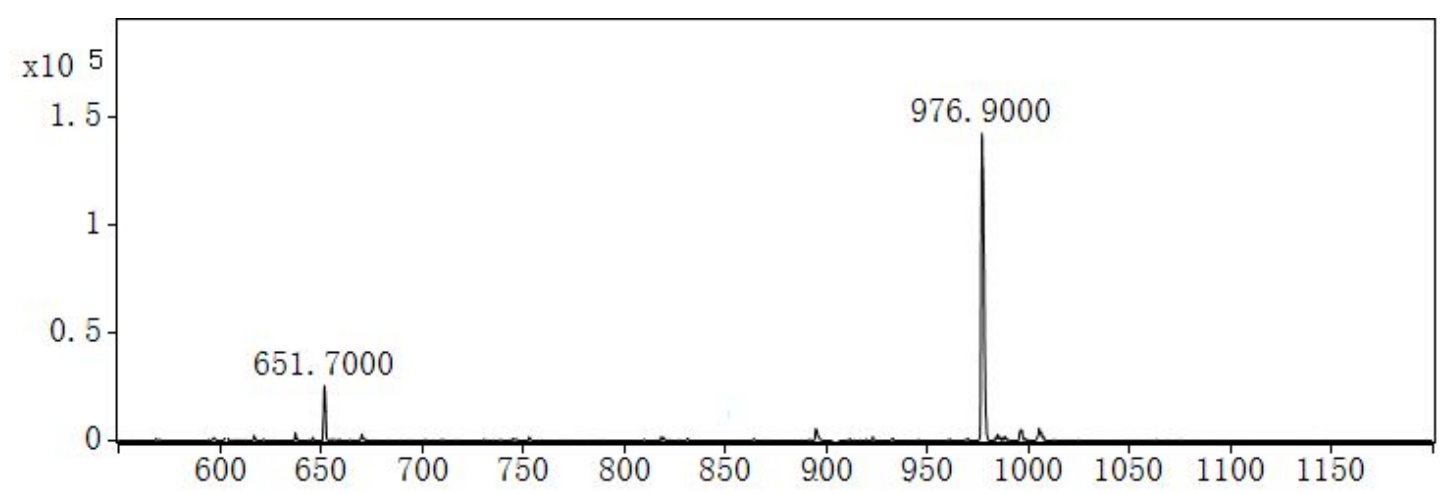

Figure S53. Mass spectrum for compound HYL-33

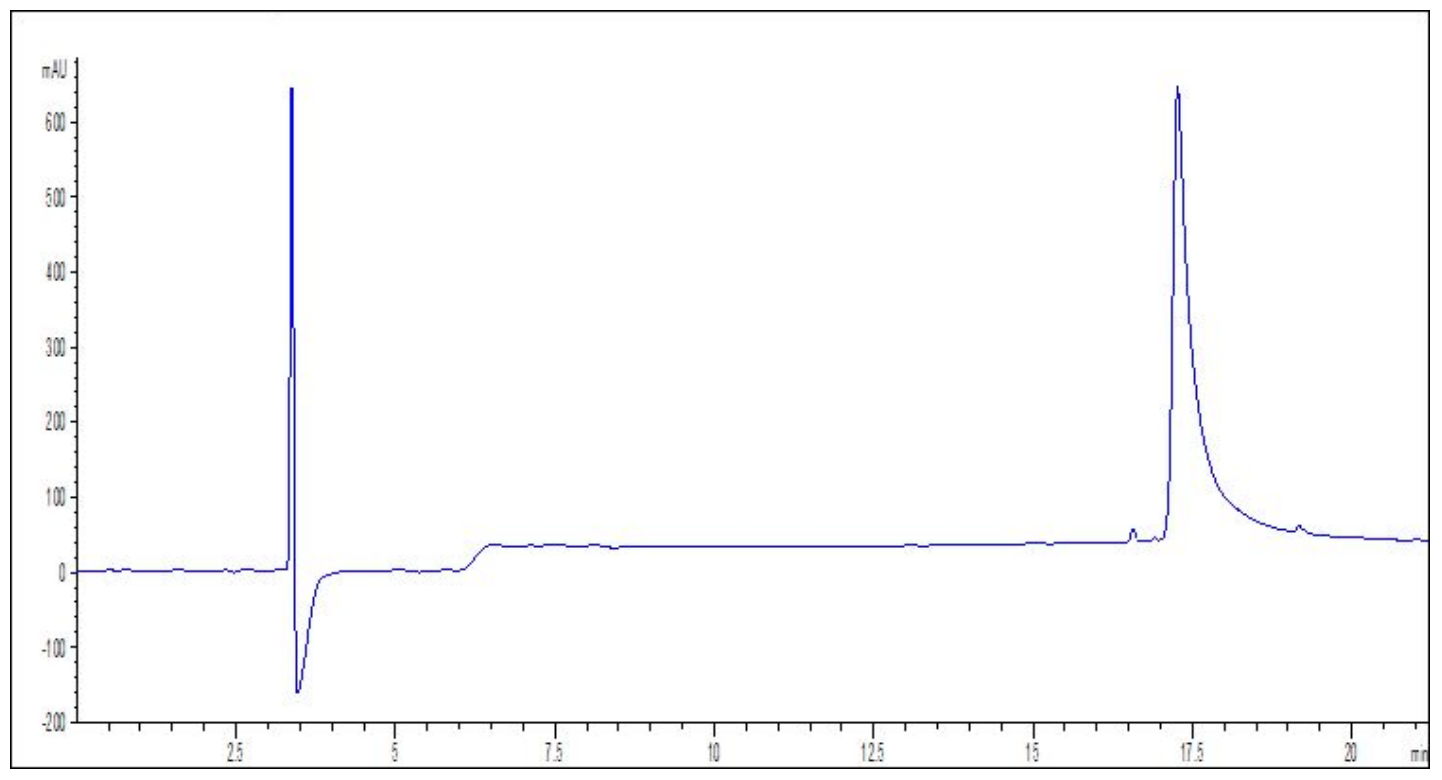

Figure S54. Analytical HPLC trace for compound HYL-34

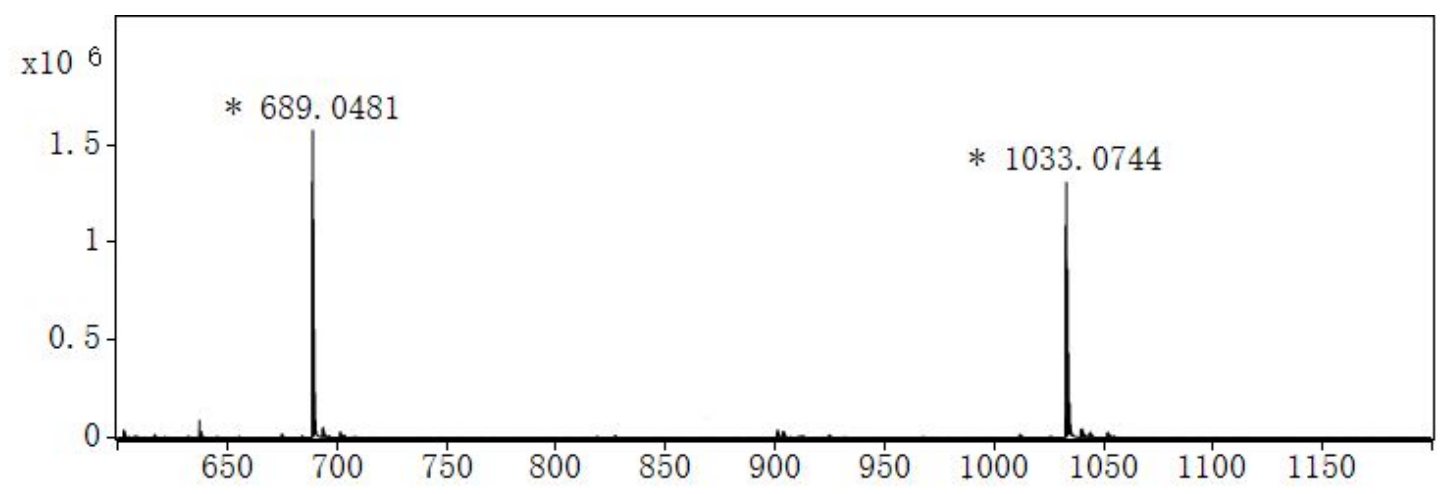

Figure S55. Mass spectrum for compound HYL-34 (Ac) 


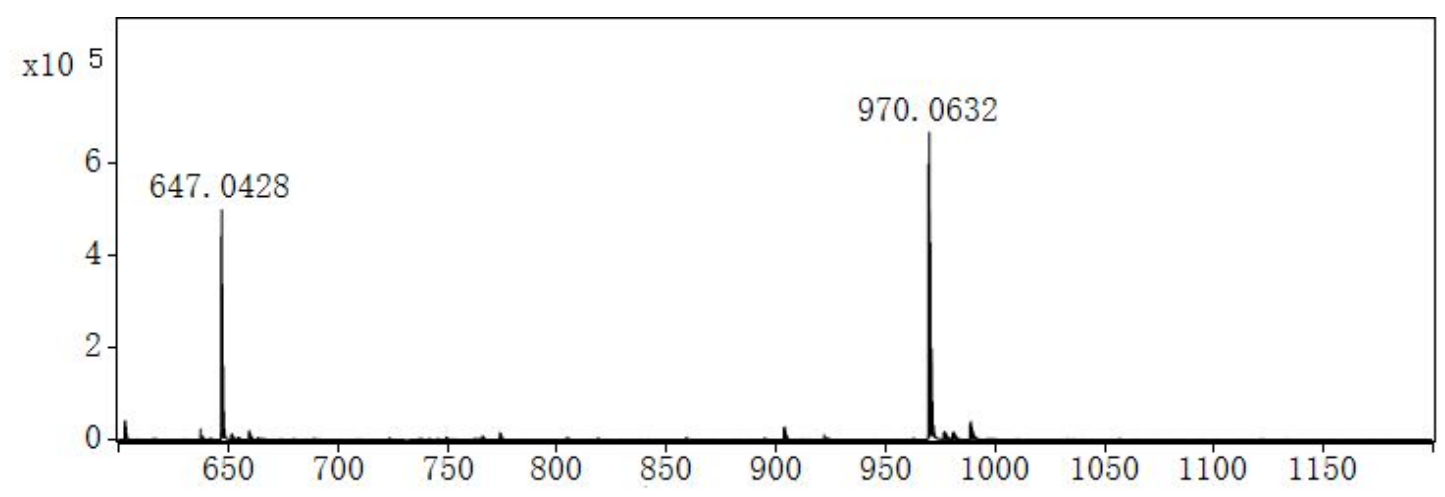

Figure S56. Mass spectrum for compound HYL-34

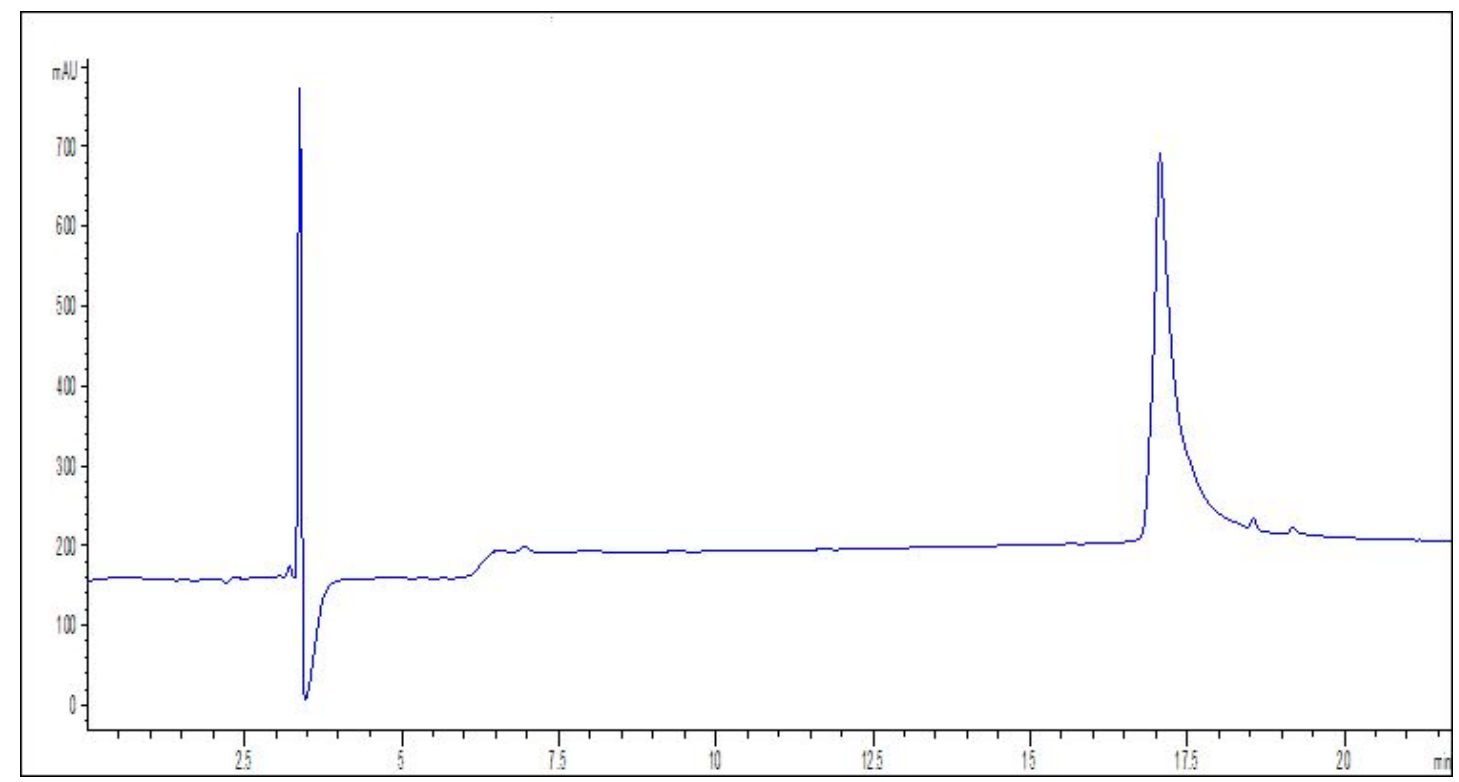

Figure S57. Analytical HPLC trace for compound HYL-35

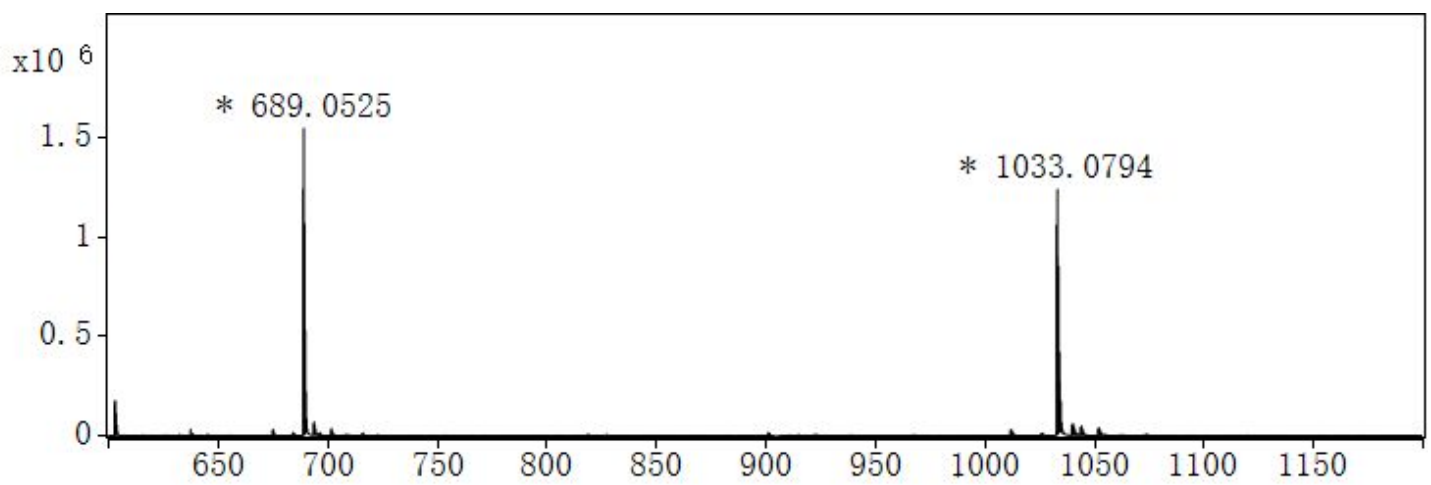

Figure S58. Mass spectrum for compound HYL-35（Ac） 


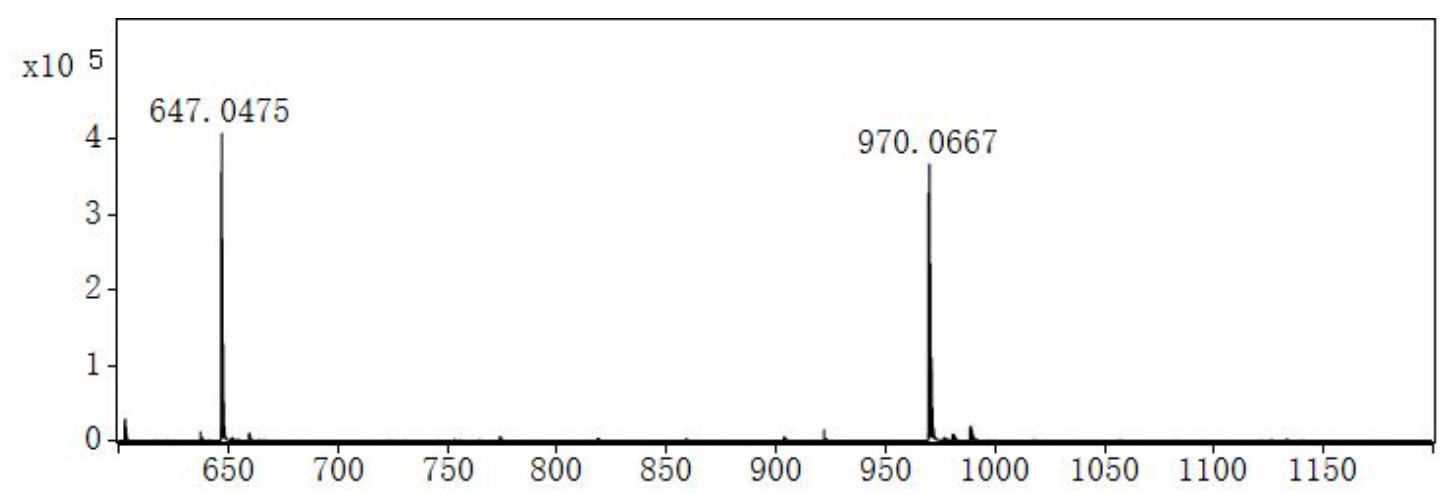

Figure S59. Mass spectrum for compound HYL-35

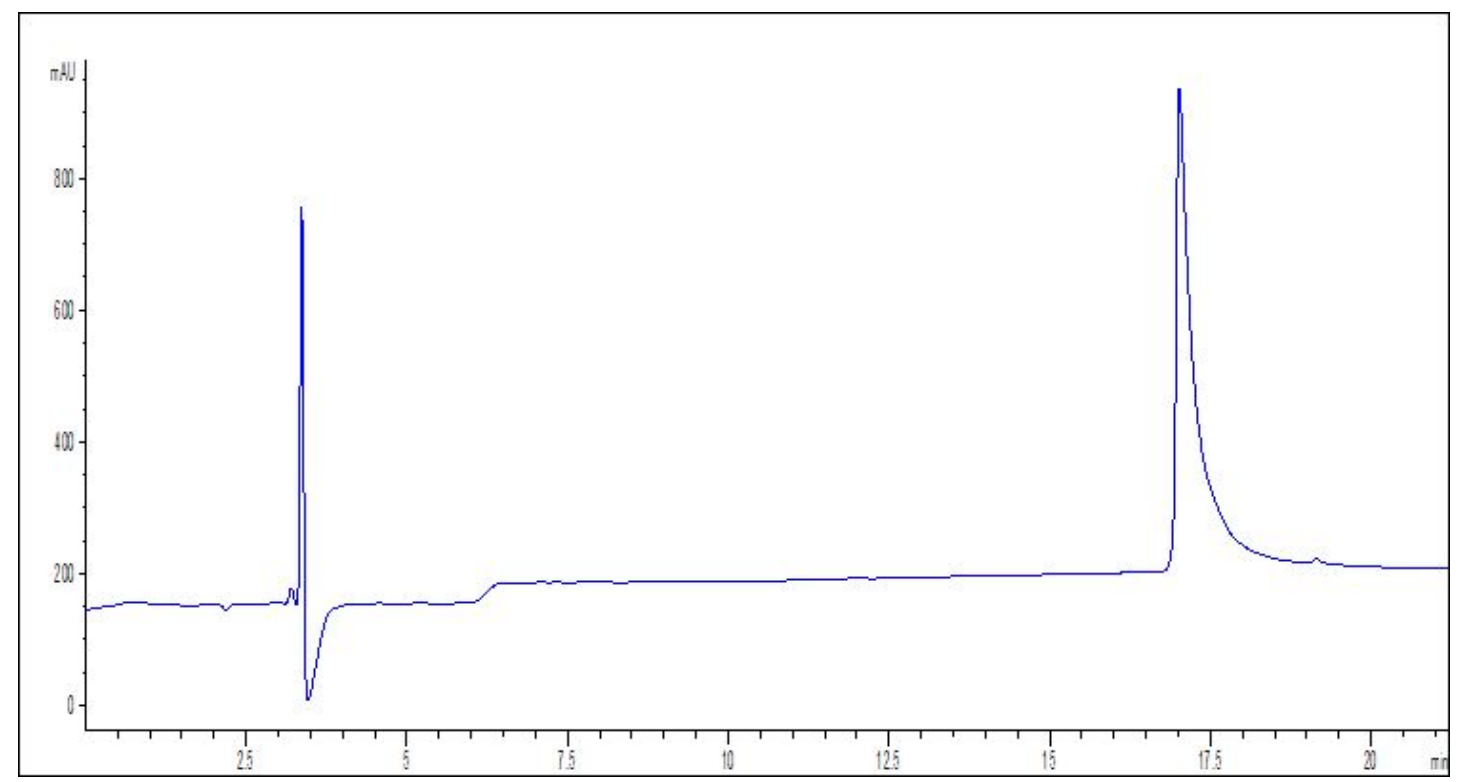

Figure S60. Analytical HPLC trace for compound HYL-36

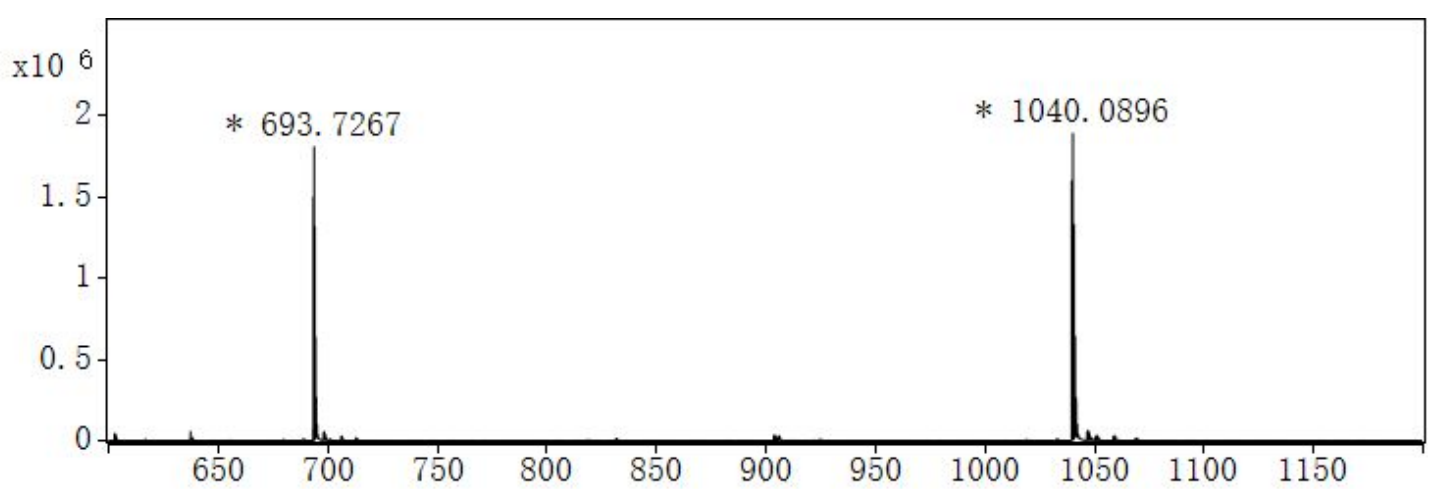

Figure S61. Mass spectrum for compound HYL-36（Ac） 


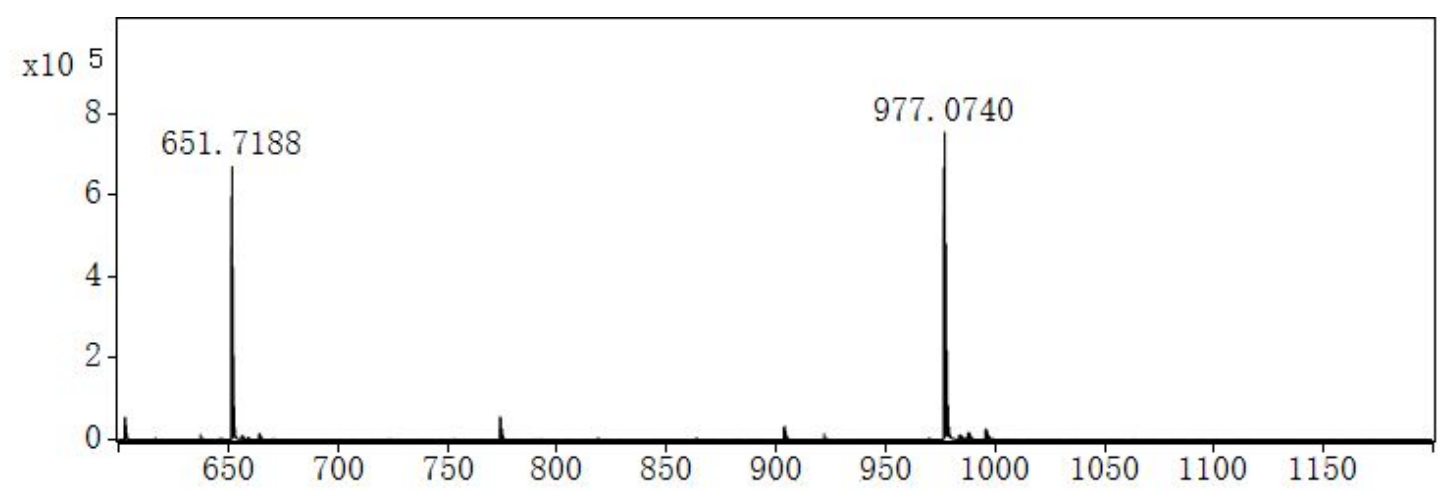

Figure S62. Mass spectrum for compound HYL-36

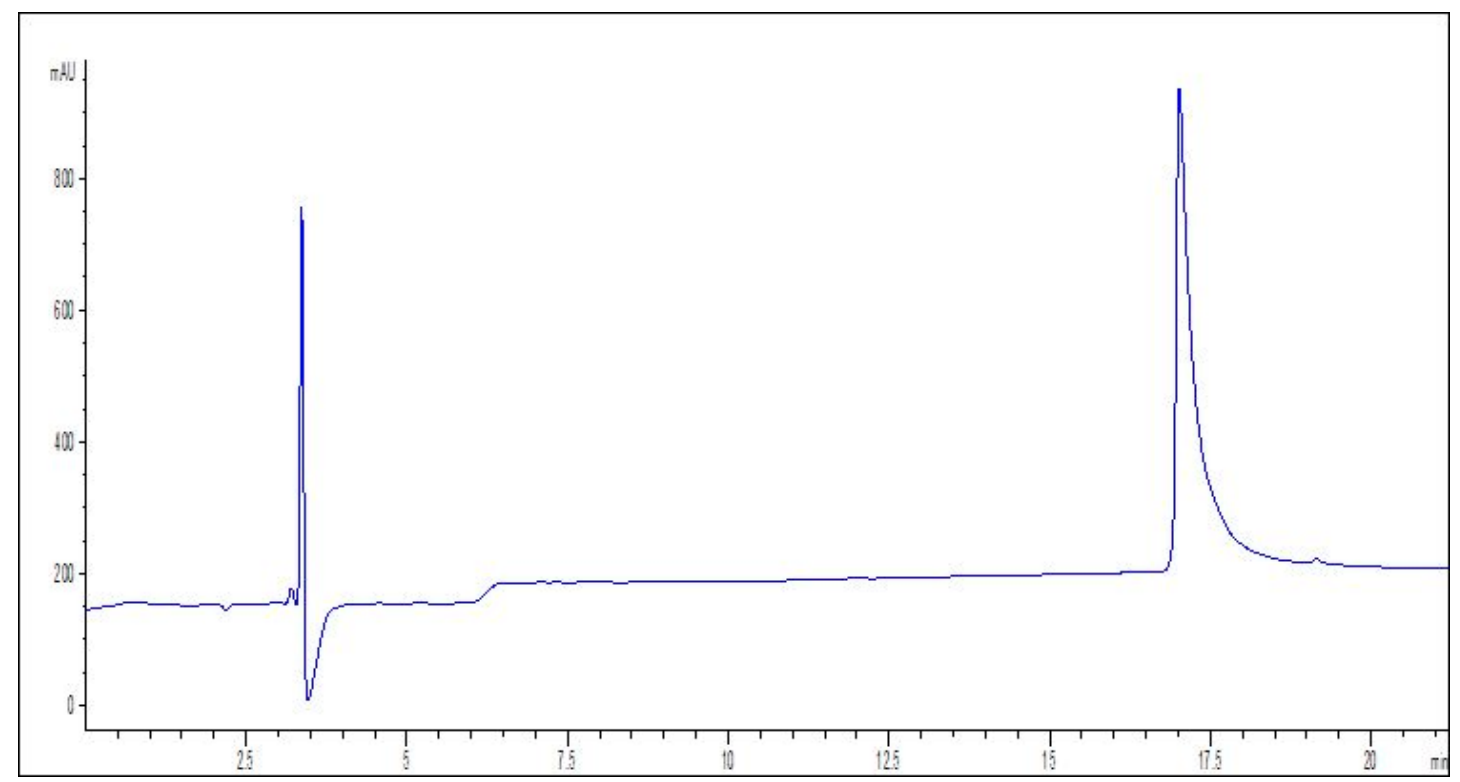

Figure S63. Analytical HPLC trace for compound HYL-37

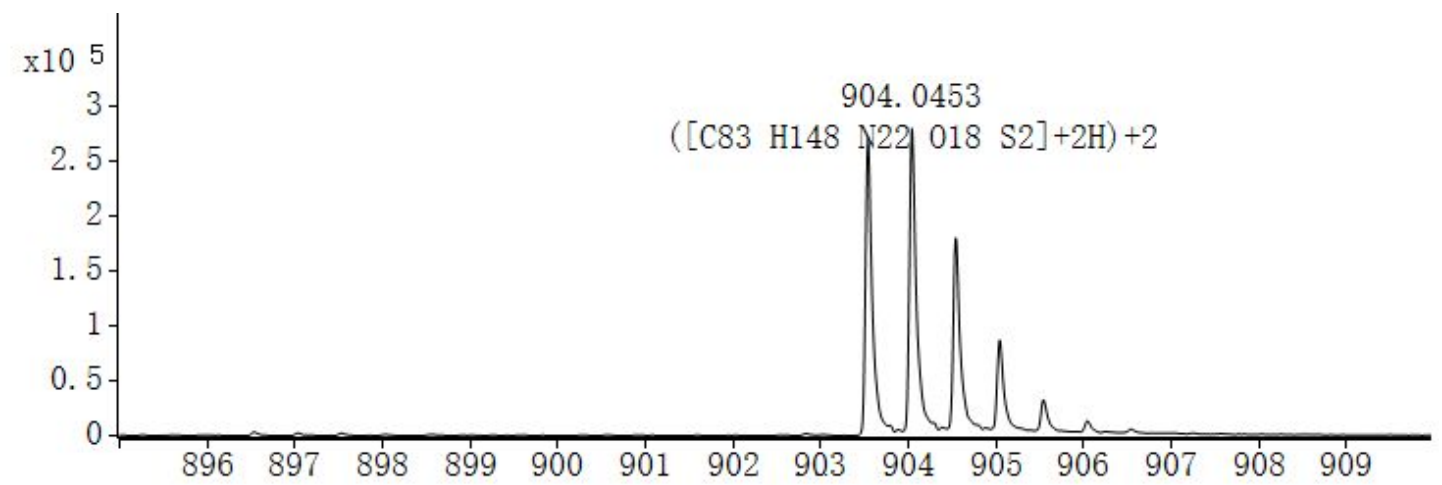

Figure S64. Mass spectrum for compound HYL-37 


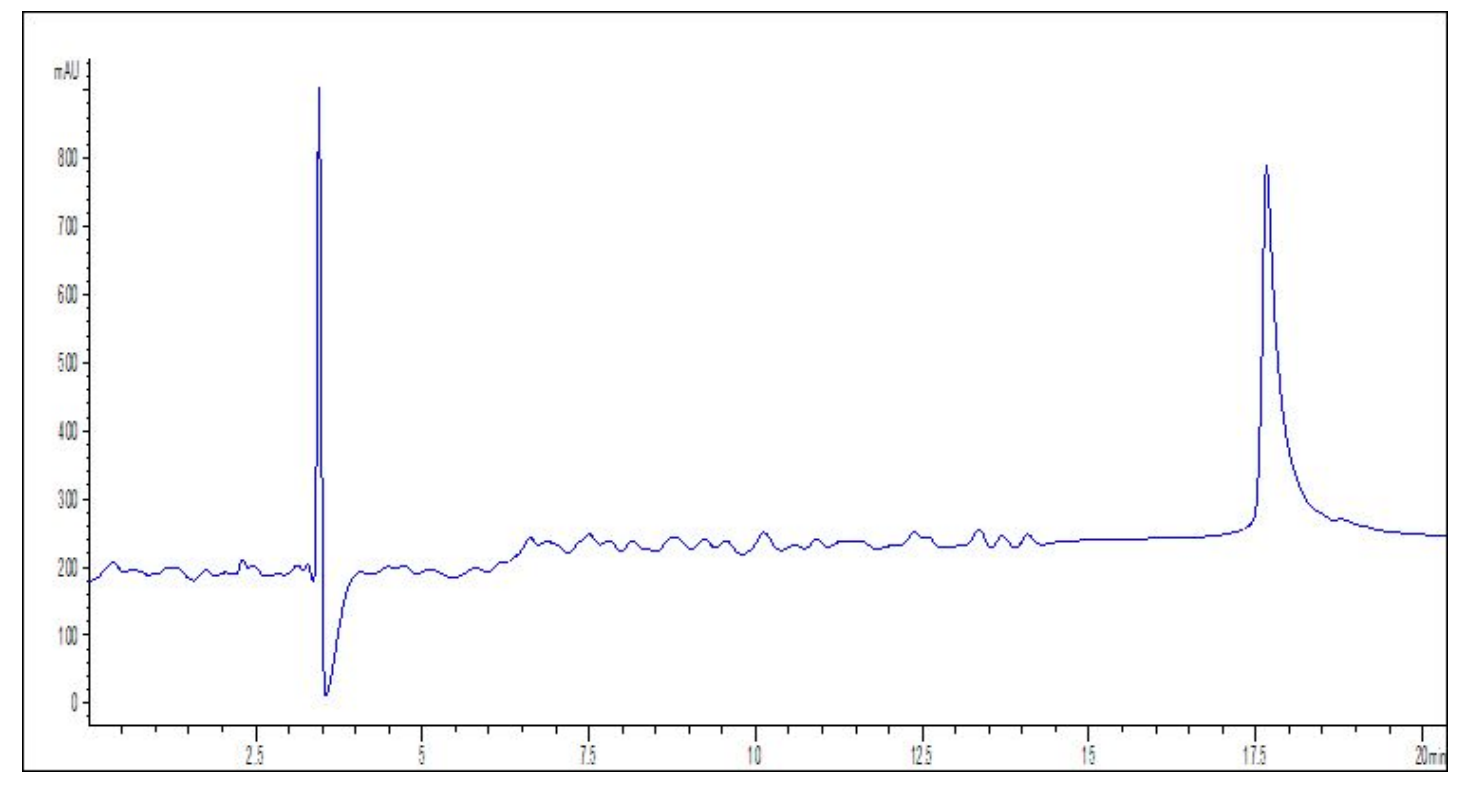

Figure S65. Analytical HPLC trace for compound HYL-38

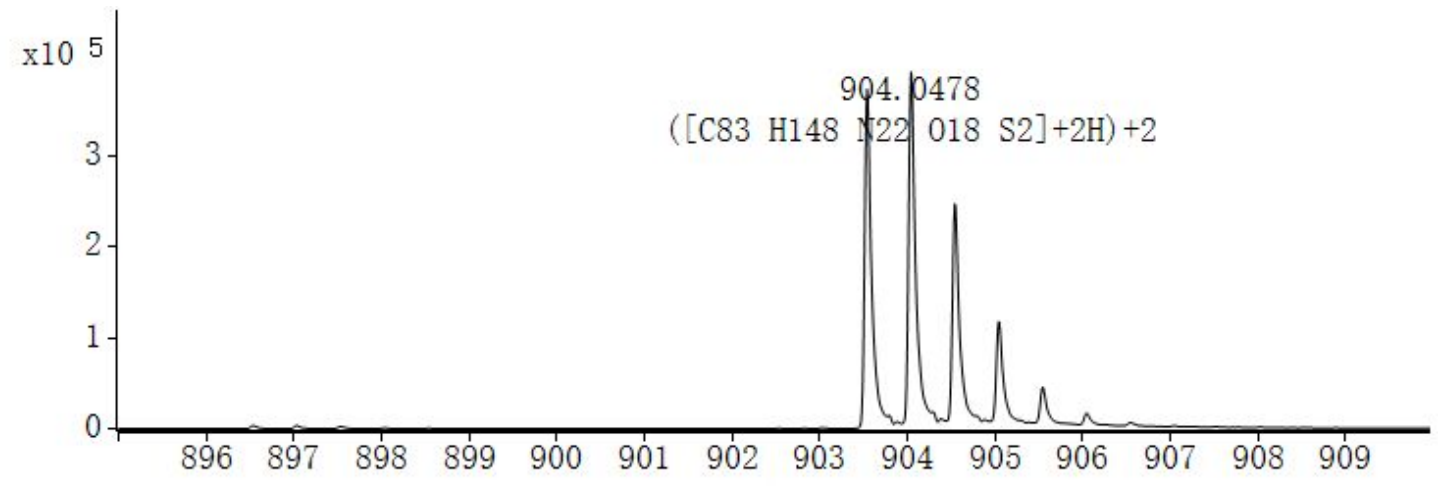

Figure S66. Mass spectrum for compound HYL-38

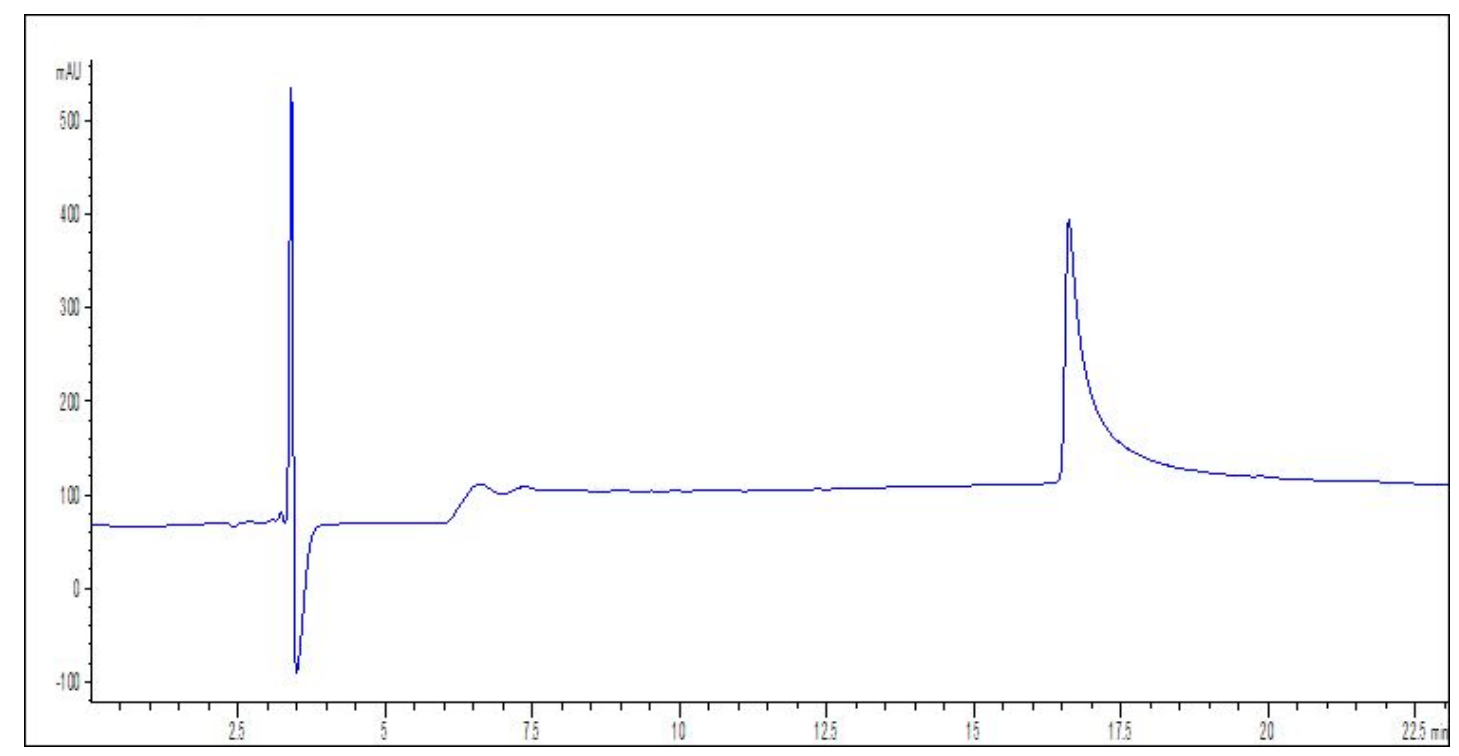

Figure S67. Analytical HPLC trace for compound HYL-39 


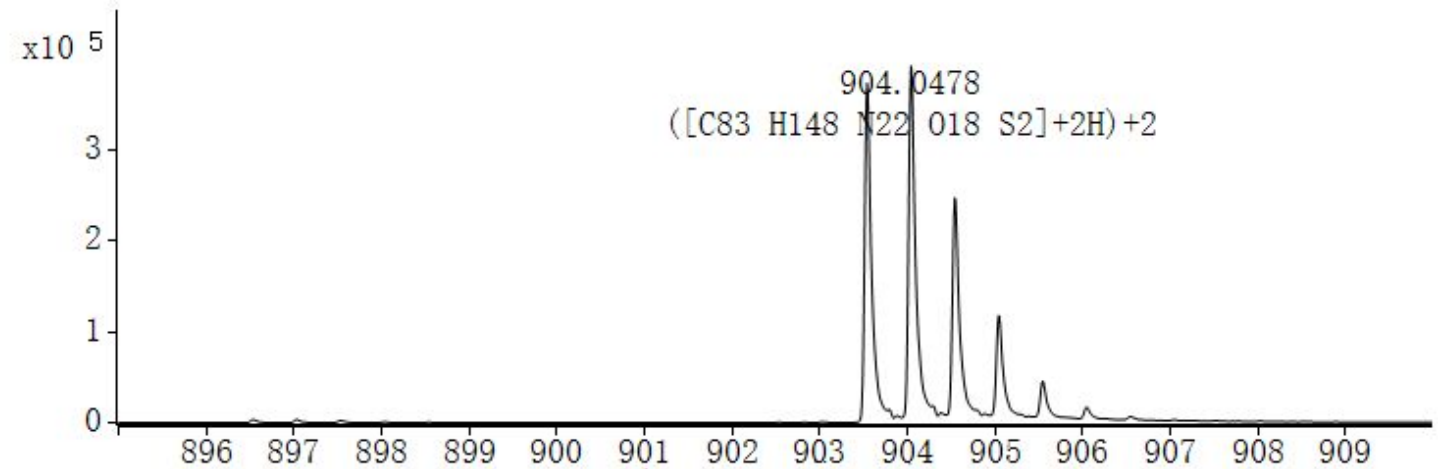

Figure S68. Mass spectrum for compound HYL-39

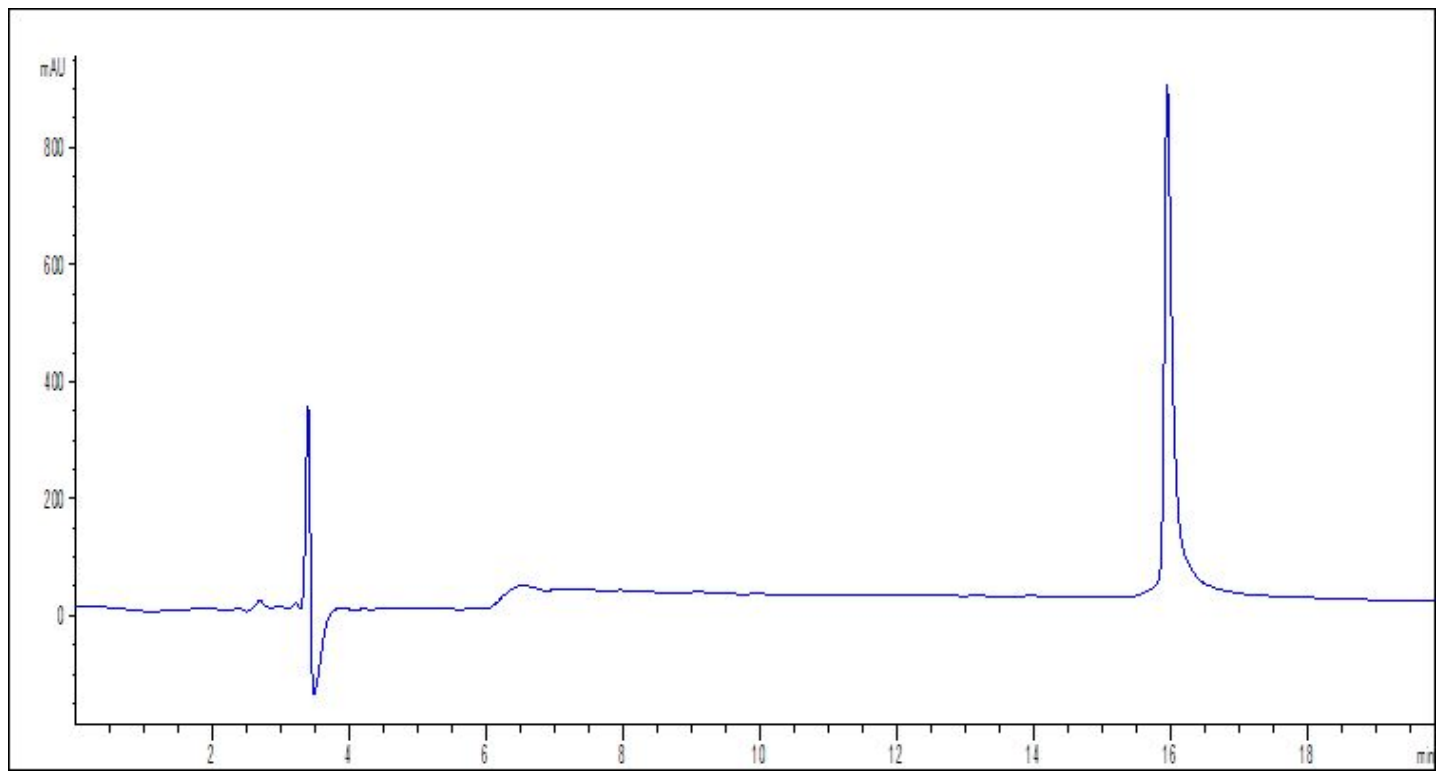

Figure S69. Analytical HPLC trace for compound HYL-40

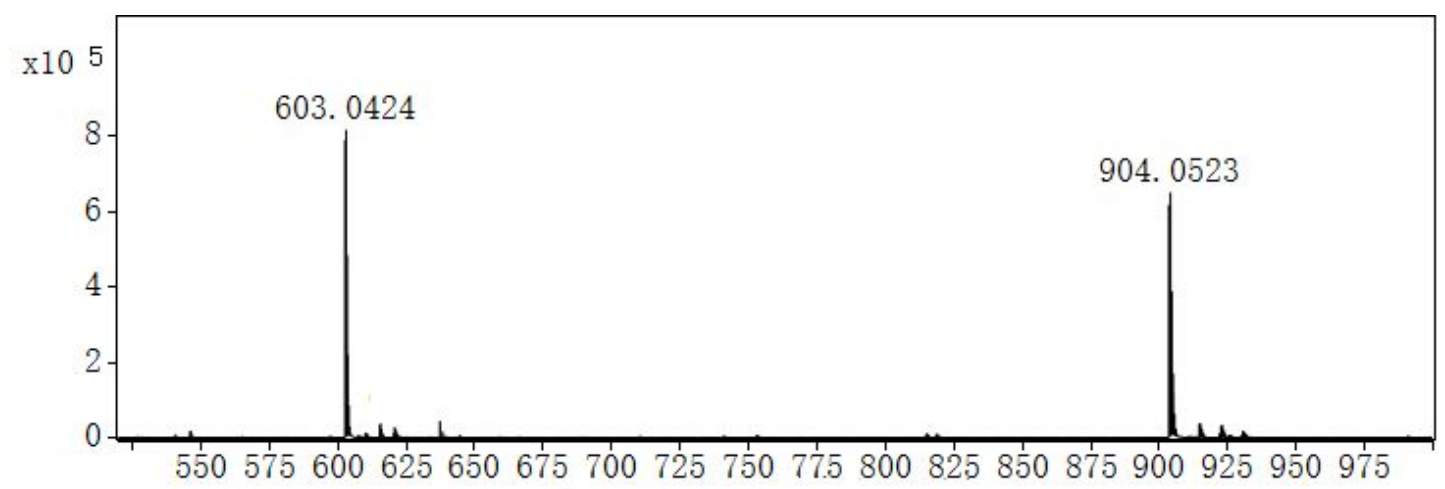

Figure S70. Mass spectrum for compound HYL-40 


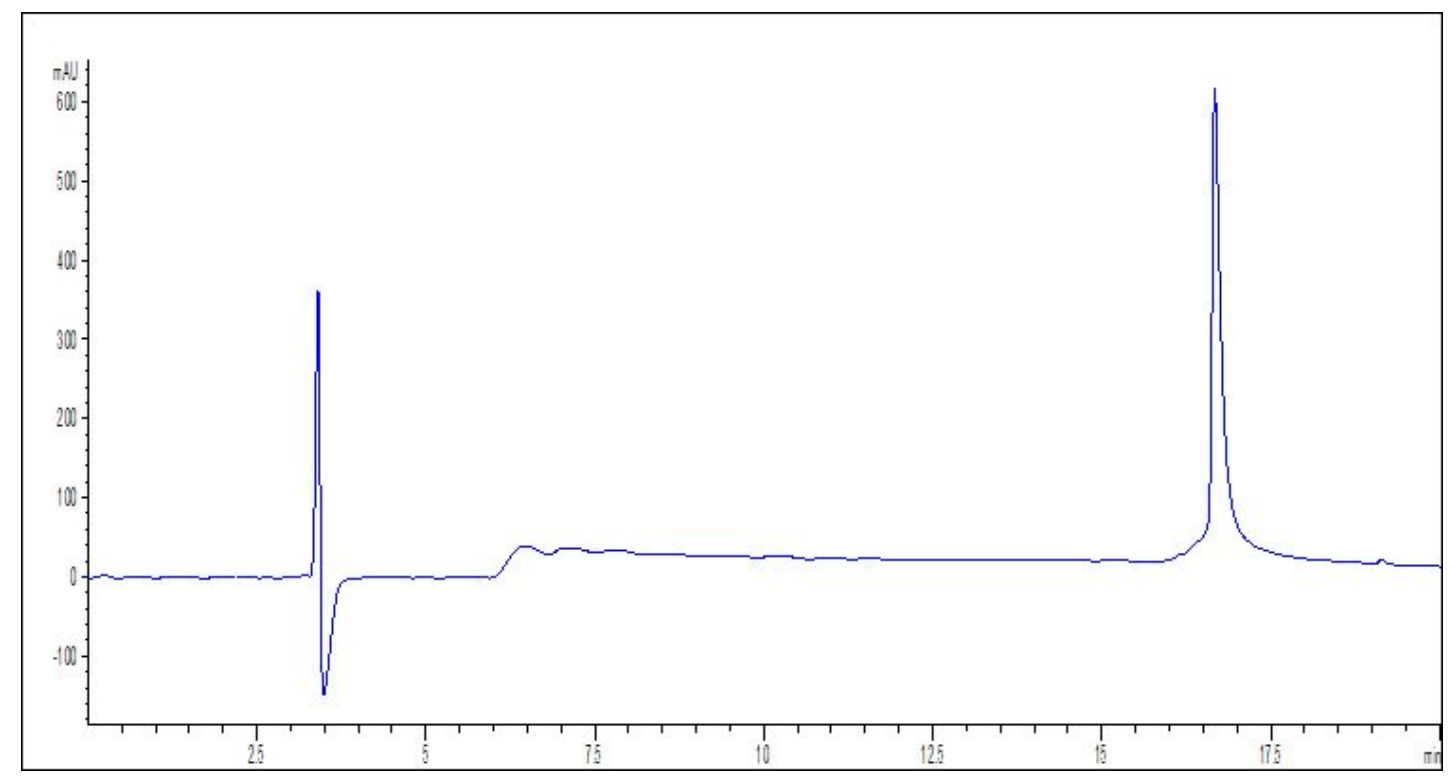

Figure S71. Analytical HPLC trace for compound HYL-41

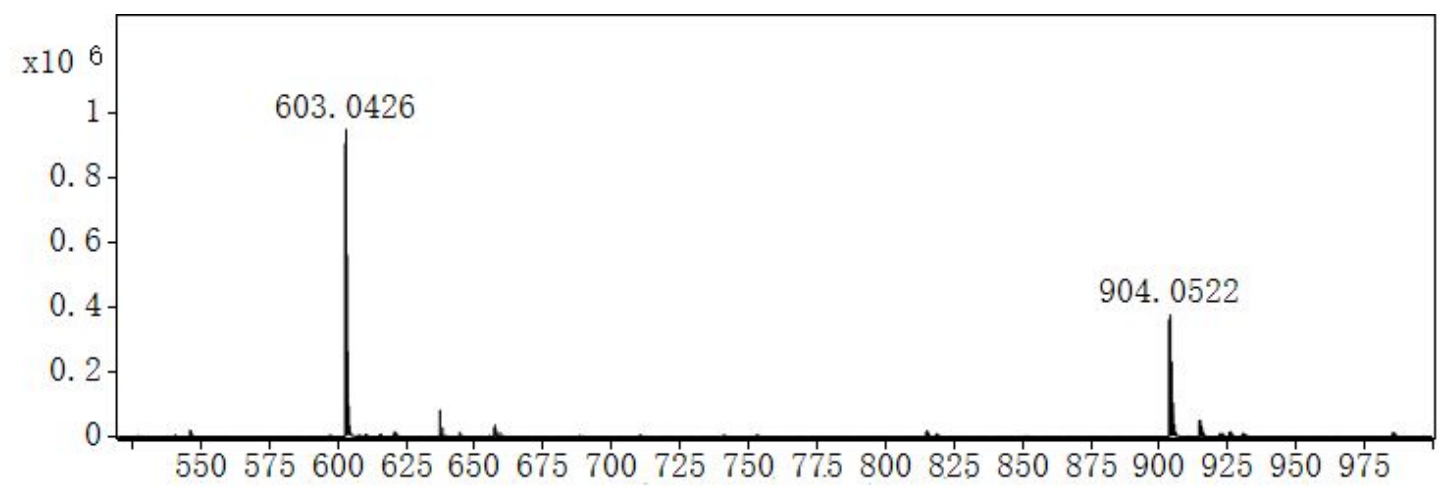

Figure S72. Mass spectrum for compound HYL-41

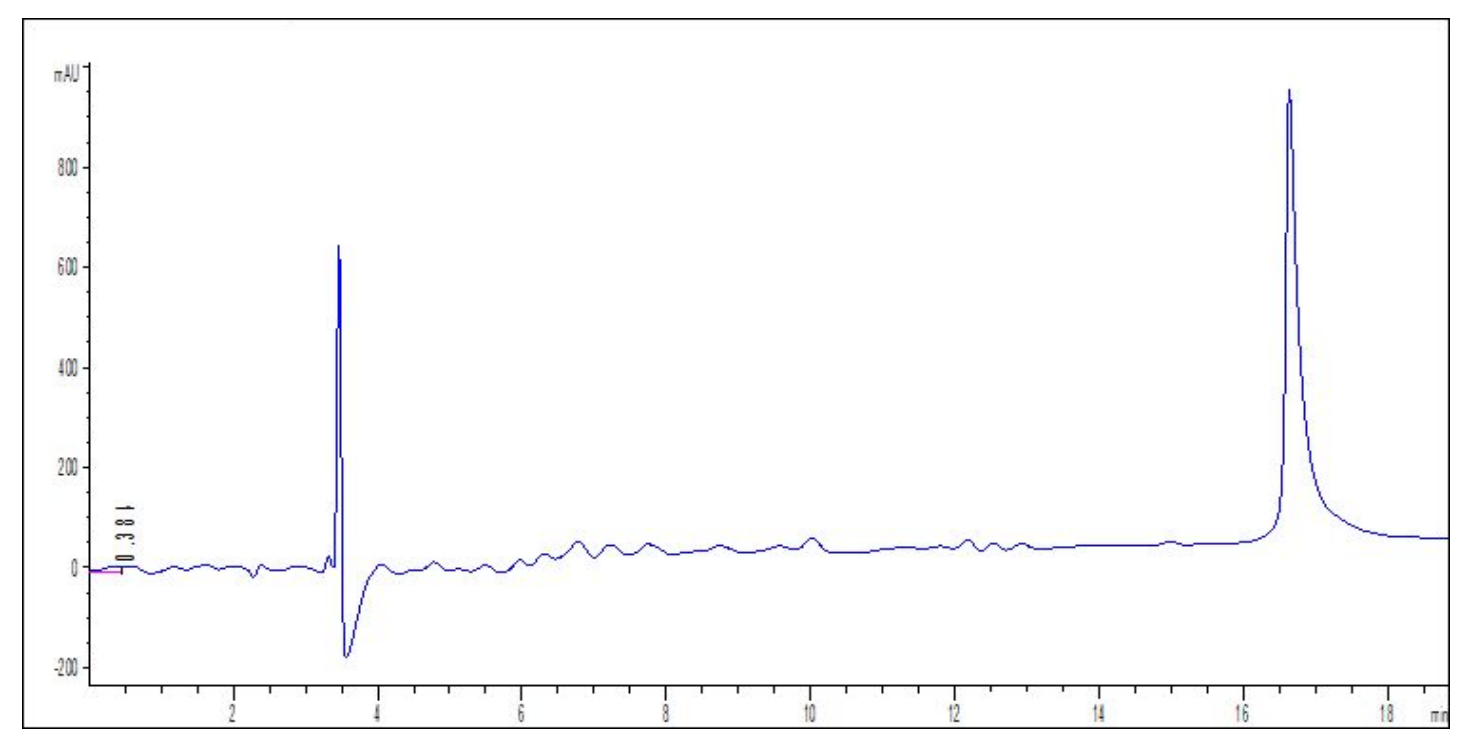

Figure S73. Analytical HPLC trace for compound HYL-42 


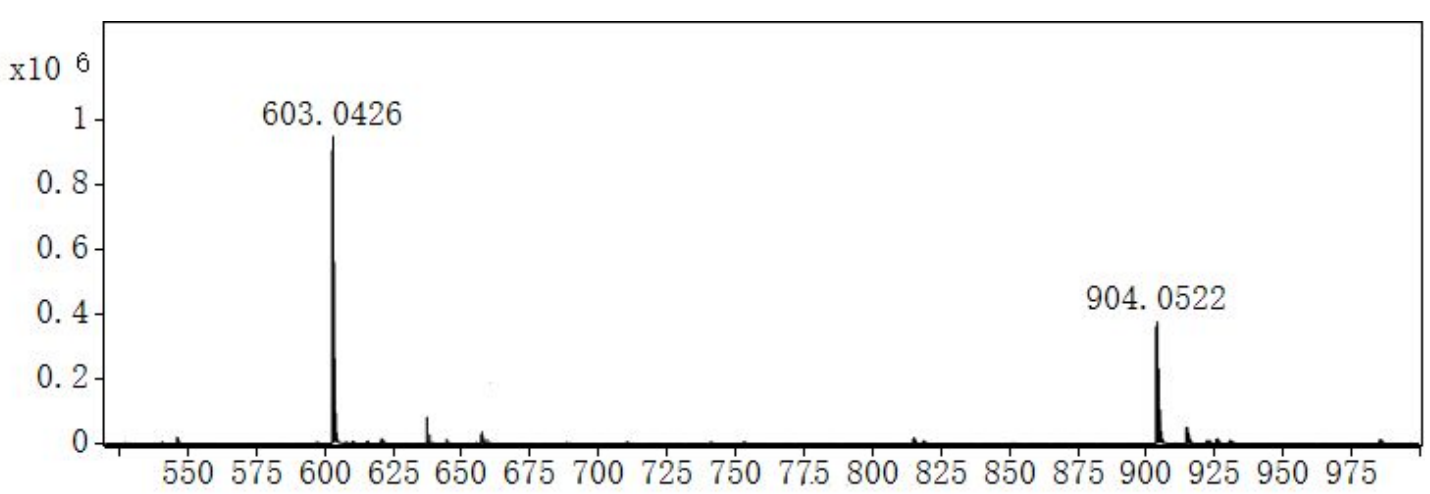

Figure S74. Mass spectrum for compound HYL-42

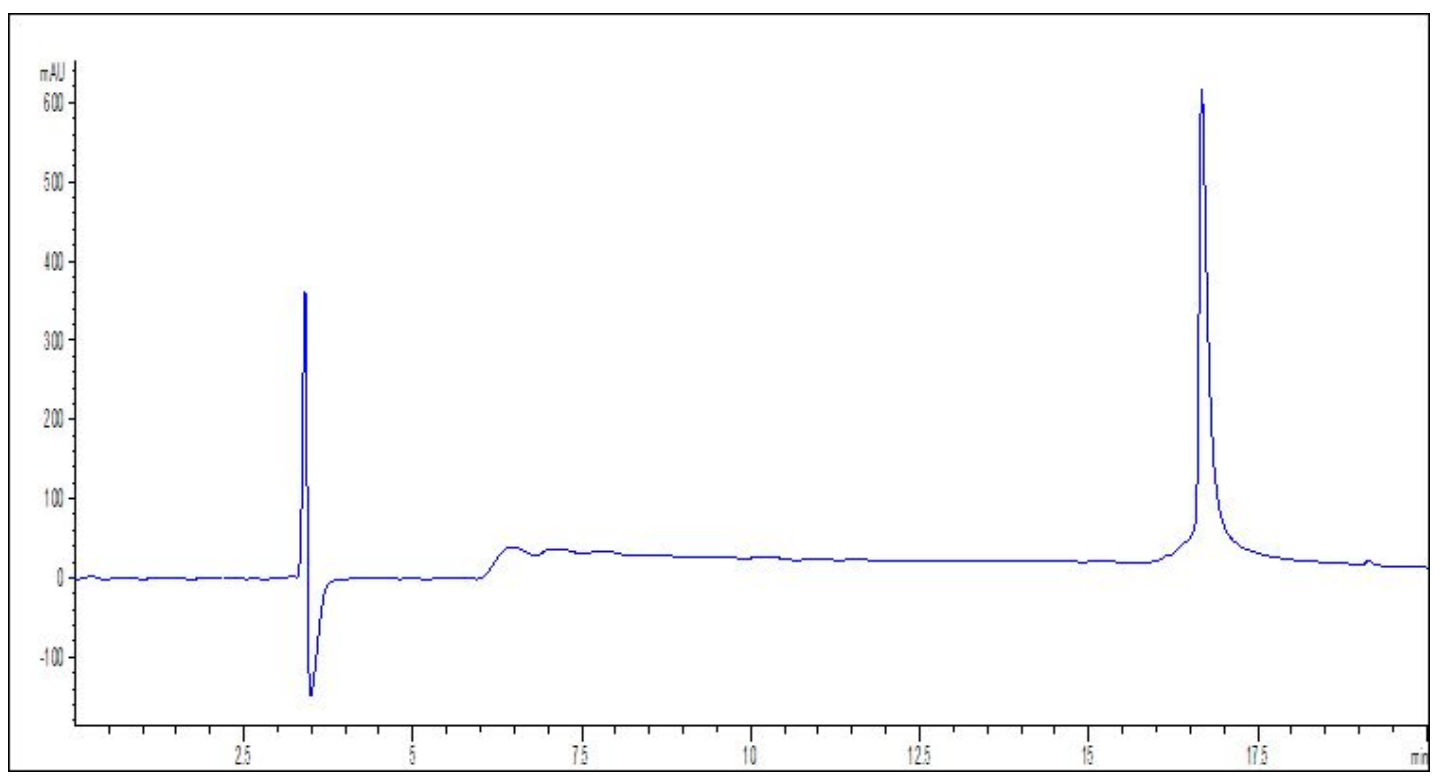

Figure S75. Analytical HPLC trace for compound HYL-43

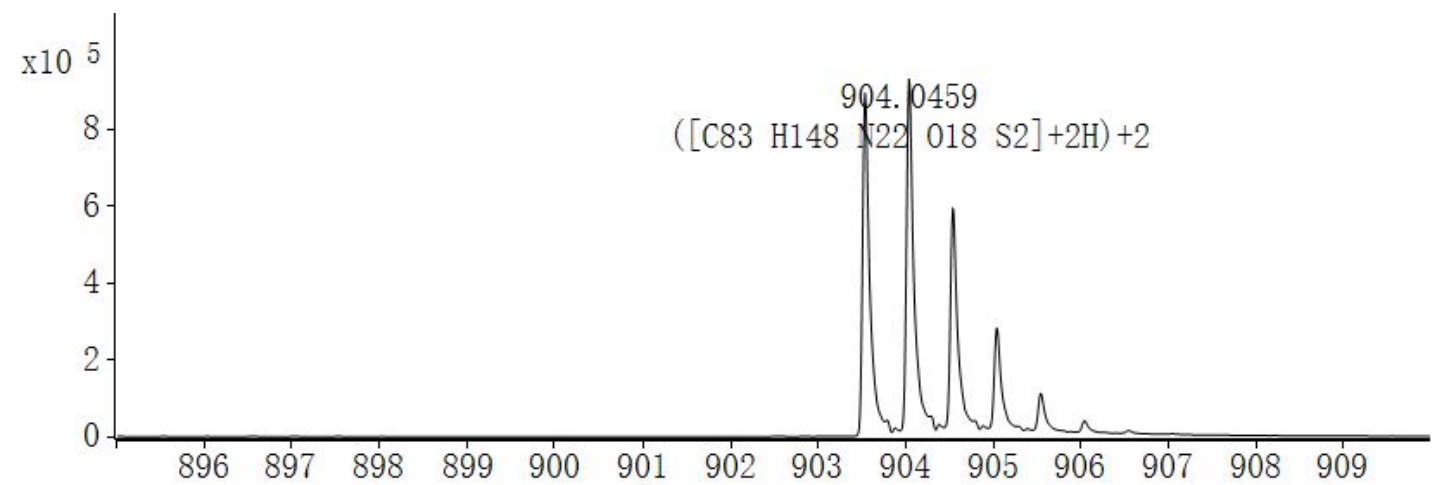

Figure S76. Mass spectrum for compound HYL-43 


\section{${ }^{1} \mathrm{H}-\mathrm{NMR},{ }^{13} \mathrm{C}-\mathrm{NMR}$, ESI-MS for glycoamino acids}

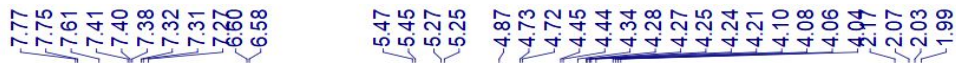

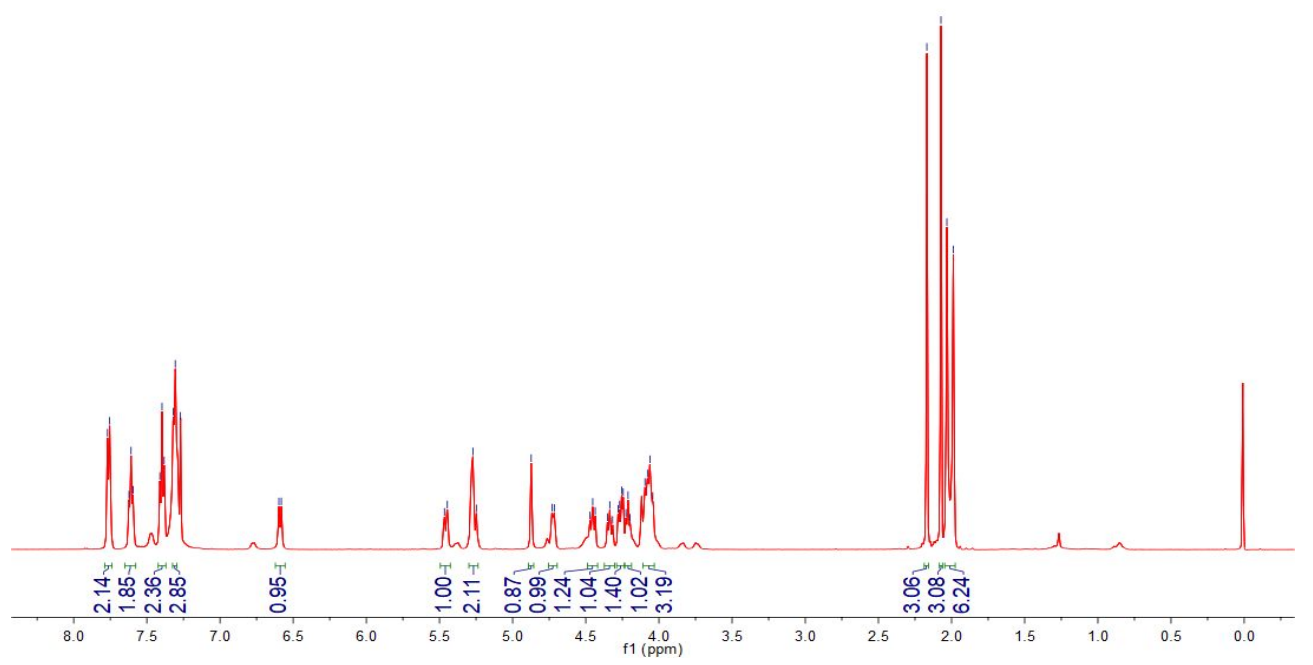

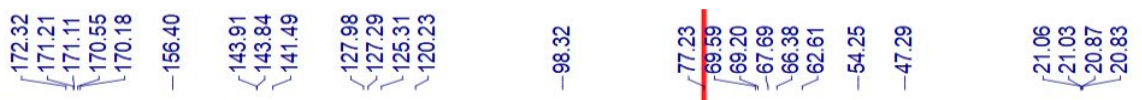
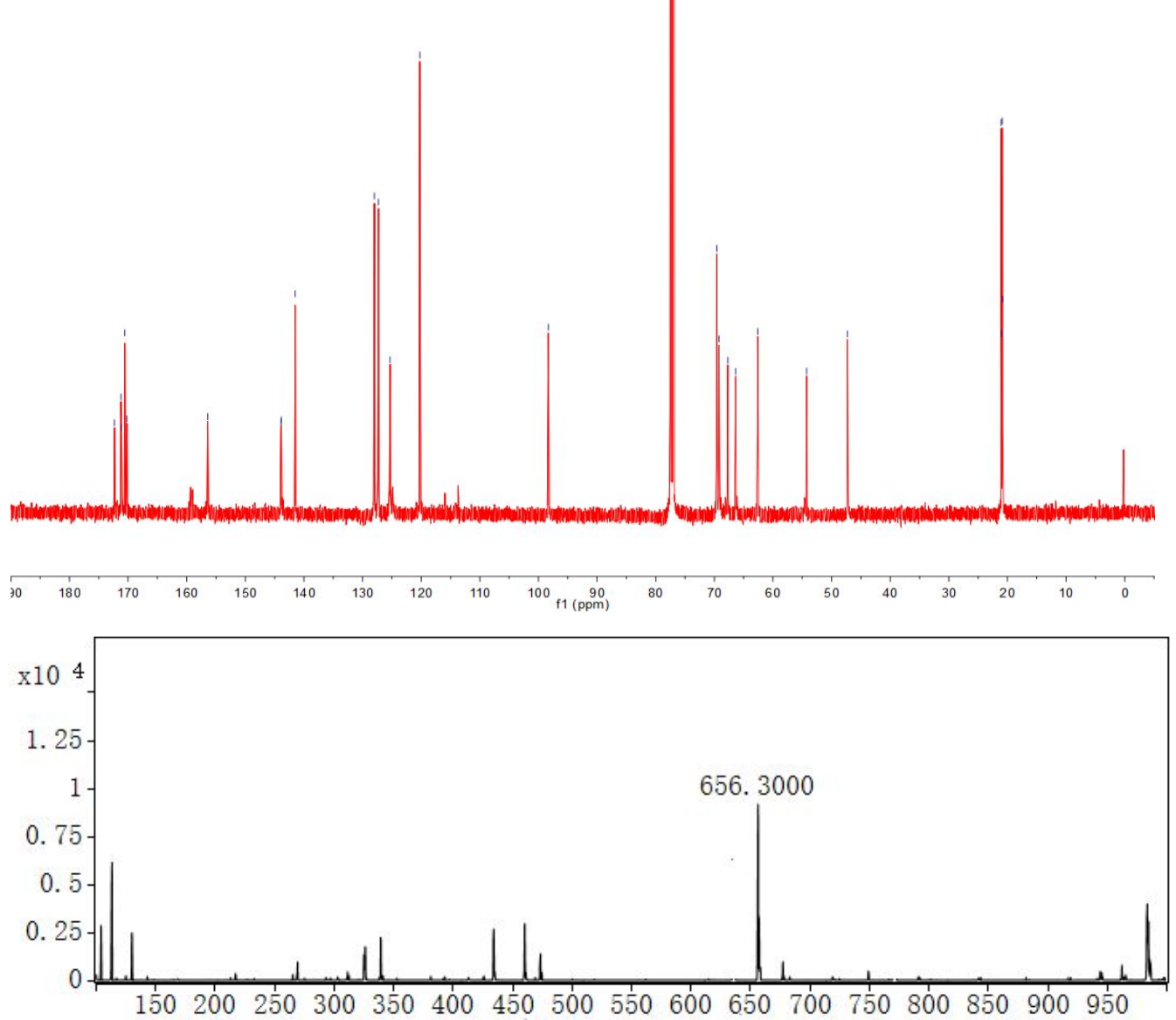

Figure S77. ${ }^{1} \mathrm{H}-\mathrm{NMR},{ }^{13} \mathrm{C}-\mathrm{NMR}$, ESI-MS of Fmoc-Ser[Glc(AC $\left.\left.\mathbf{C}_{3}\right) \mathbf{N A c} \boldsymbol{\beta}\right]-\mathbf{O H}\left({ }^{1} \mathrm{H}\right.$ NMR $(500$ 
MHz, DMSO-d $\left.\mathrm{d}_{6}\right)--\delta 7.92(\mathrm{~d}, J=5.0 \mathrm{~Hz}, 1 \mathrm{H}), 7.88(\mathrm{~d}, J=5.0 \mathrm{~Hz}, 2 \mathrm{H}), 7.74-7.72(\mathrm{~m}, 2 \mathrm{H}), 7.62(\mathrm{~d}$, $J=10.0 \mathrm{~Hz}, 1 \mathrm{H}), 7.41(\mathrm{t}, J=5.0 \mathrm{~Hz}, 2 \mathrm{H}), 7.33(\mathrm{t}, J=5.0 \mathrm{~Hz}, 2 \mathrm{H}), 5.75(\mathrm{~d}, J=5.0 \mathrm{~Hz}, 1 \mathrm{H}), 5.18(\mathrm{t}, J$ $=10.0 \mathrm{~Hz}, 1 \mathrm{H}), 4.89(\mathrm{t}, J=10.0 \mathrm{~Hz}, 1 \mathrm{H}), 4.32-4.18(\mathrm{~m}, 4 \mathrm{H}), 4.14-4.10(\mathrm{~m}, 1 \mathrm{H}), 4.02-3.96(\mathrm{~m}, 3 \mathrm{H})$, 3.69-3.62(m, 2H), 1.96(s, 3H), 1.95(s, 3H) , 1.92(s, 3H) , 1.77(s, 3H); ${ }^{13} \mathrm{C} \quad \mathrm{NMR}$ (125MHz,DMSO-d6) -- $\delta$ 170.43, 170.15, 169.97, 169.68, 169.61, 156.41, 144.27, 144.20,141.16, $128.10,127.55,127.53,125.76,125.70,120.56,93.03,72.45,72.10,68.60,66.36,61.88,61.10$ 57.09, 52.44, 47.01, 23.03, 20.91, 20.83, 20.77.)

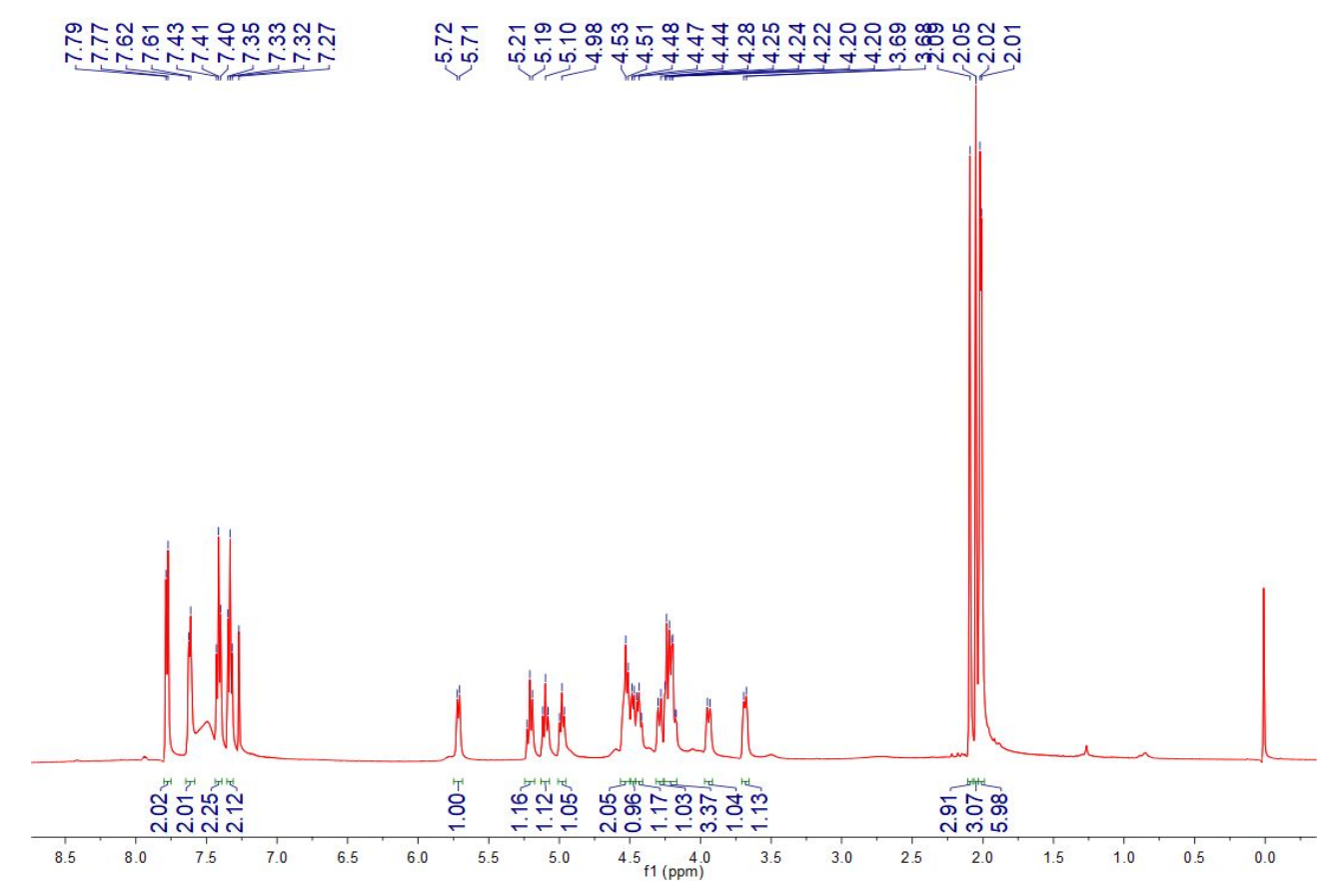




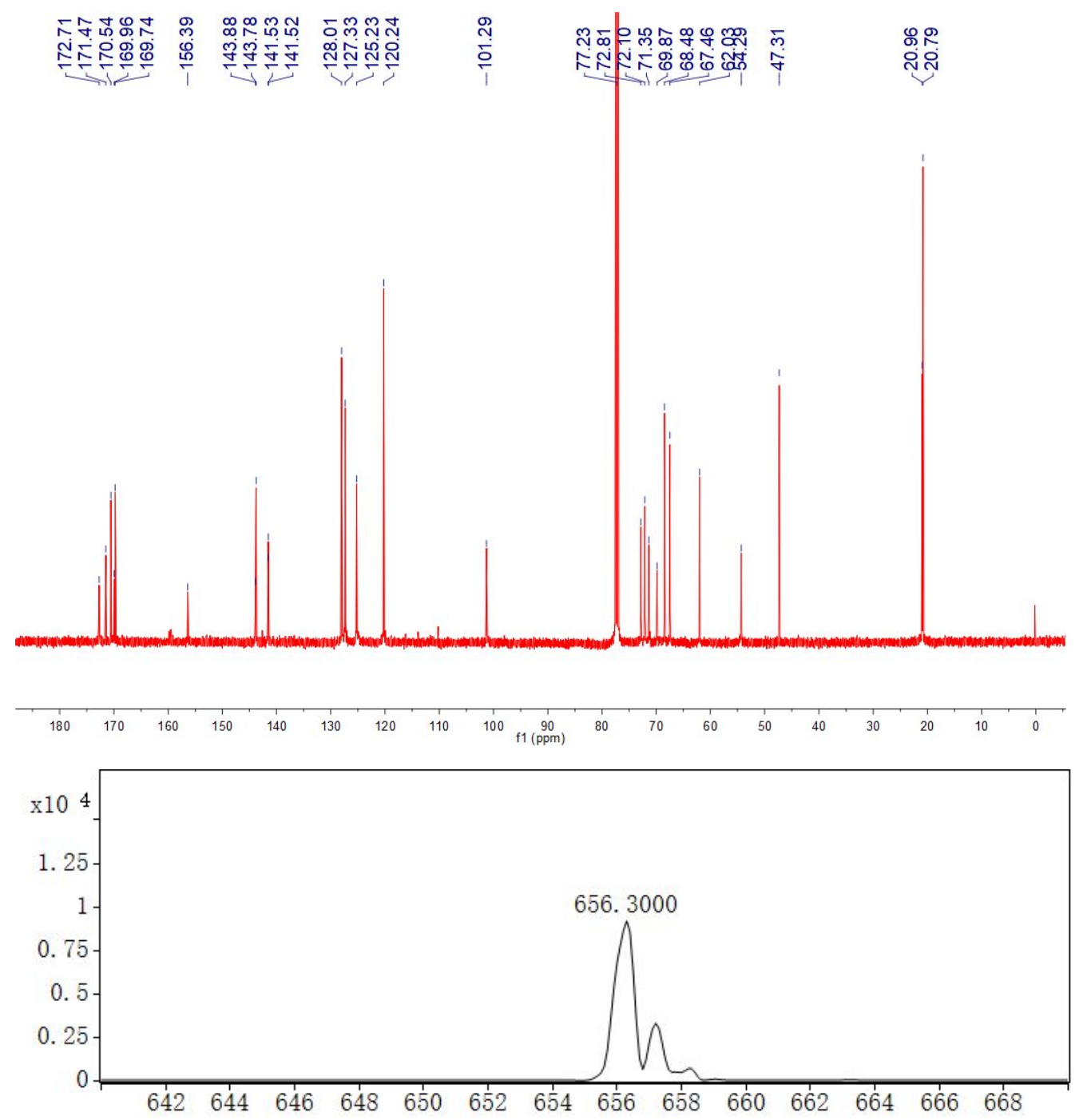

Figure S78. ${ }^{1} \mathrm{H}-\mathrm{NMR},{ }^{13} \mathrm{C}-\mathrm{NMR}$, ESI-MS of Fmoc-Ser[Gle(AC $\left.\left.\mathbf{A}_{4}\right) \boldsymbol{\beta}\right]-\mathrm{OH}\left({ }^{1} \mathrm{H}\right.$ NMR $(500 \mathrm{MHz}$, $\left.\mathrm{CDCl}_{3}\right)--\delta 7.78(\mathrm{~d}, J=7.5 \mathrm{~Hz}, 2 \mathrm{H}), 7.62(\mathrm{~d}, J=6.8 \mathrm{~Hz}, 2 \mathrm{H}), 7.41(\mathrm{t}, J=7.4 \mathrm{~Hz}, 2 \mathrm{H}), 7.33(\mathrm{t}, J=$ $7.4 \mathrm{~Hz}, 2 \mathrm{H}), 5.71(\mathrm{~d}, J=7.8 \mathrm{~Hz}, 1 \mathrm{H}), 5.21(\mathrm{t}, J=9.3 \mathrm{~Hz}, 1 \mathrm{H}), 5.10(\mathrm{t}, J=9.5 \mathrm{~Hz}, 1 \mathrm{H}), 4.98(\mathrm{t}, J=$ $8.5 \mathrm{~Hz}, 1 \mathrm{H}), 4.52(\mathrm{~d}, J=8.4 \mathrm{~Hz}, 2 \mathrm{H}), 4.48(\mathrm{~d}, J=7.2 \mathrm{~Hz}, 1 \mathrm{H}), 4.46-4.41(\mathrm{~m}, 1 \mathrm{H}), 4.29(\mathrm{~d}, J=10.2$ $\mathrm{Hz}, 1 \mathrm{H}), 4.26-4.17(\mathrm{~m}, 3 \mathrm{H}), 3.94(\mathrm{~d}, J=10.0 \mathrm{~Hz}, 1 \mathrm{H}), 3.68(\mathrm{~d}, J=9.4 \mathrm{~Hz}, 1 \mathrm{H}), 2.09(\mathrm{~s}, 3 \mathrm{H}), 2.05(\mathrm{~s}$, 3H), 2.01(d, $J=5.4 \mathrm{~Hz}, 6 \mathrm{H}) ;{ }^{13} \mathrm{C}$ NMR $\left(126 \mathrm{MHz}, \mathrm{CDCl}_{3}\right)--\delta 172.71,171.47,170.54,169.96$, $169.74,156.39,143.88,143.78,141.53,141.52,128.01,127.33,125.23,120.24,101.29,77.23$ $72.81,72.10,71.35,69.87,68.48,67.46,62.03,54.29,47.31,20.96,20.79$. 

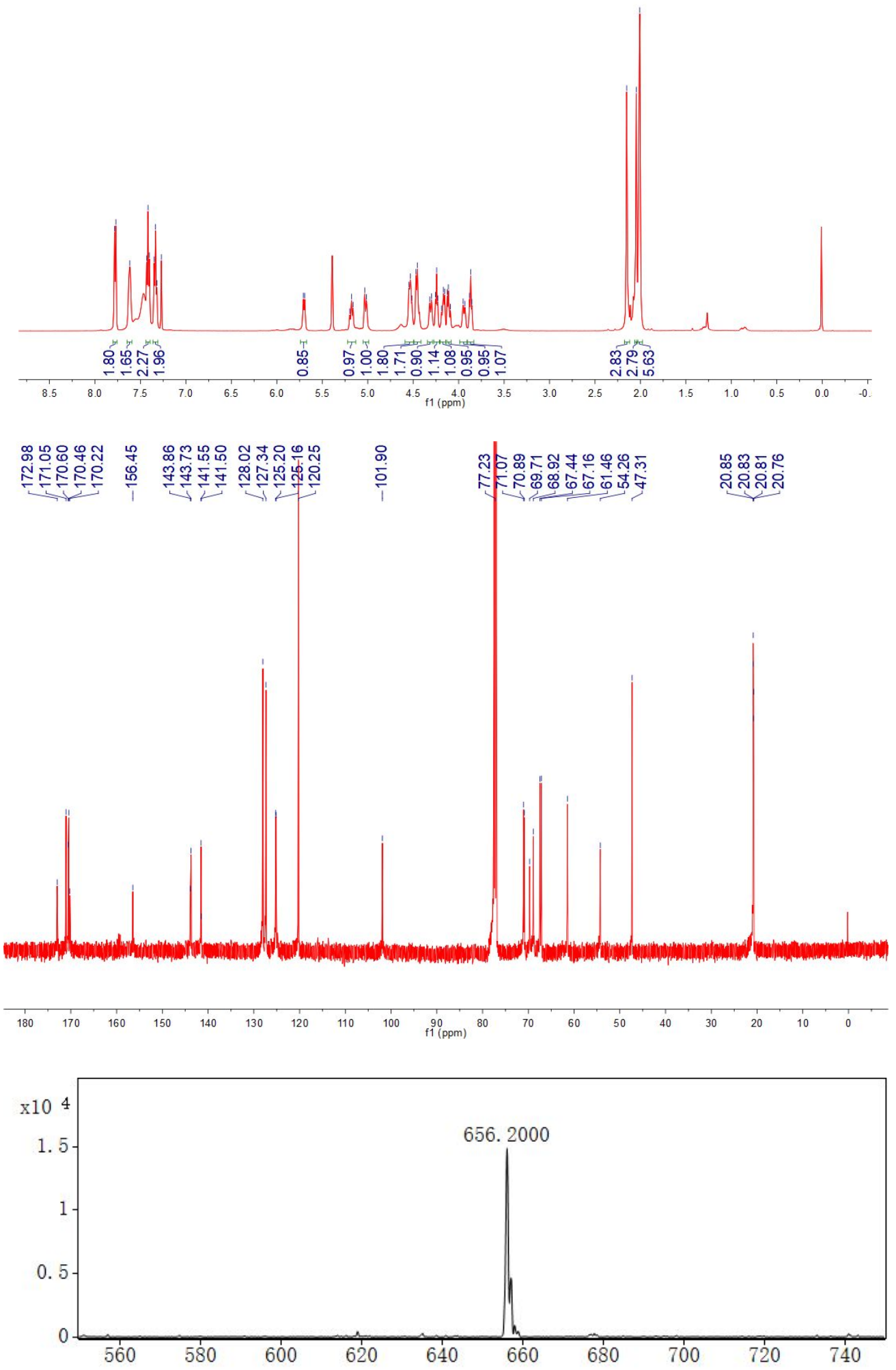

Figure S79. ${ }^{1} \mathrm{H}-\mathrm{NMR},{ }^{13} \mathrm{C}-\mathrm{NMR}$, ESI-MS of Fmoc-Ser[Gal(AC $\left.\left.\mathbf{A}_{4}\right) \boldsymbol{\beta}\right]-\mathrm{OH}\left({ }^{1} \mathrm{H}\right.$ NMR $(500 \mathrm{MHz}$, 
$\left.\mathrm{CDCl}_{3}\right)--\delta 7.78(\mathrm{~d}, J=7.5 \mathrm{~Hz}, 2 \mathrm{H}), 7.62(\mathrm{~s}, 2 \mathrm{H}), 7.42(\mathrm{t}, J=7.4 \mathrm{~Hz}, 2 \mathrm{H}), 7.33(\mathrm{t}, J=7.3 \mathrm{~Hz}, 2 \mathrm{H})$, $5.70(\mathrm{~d}, J=7.7 \mathrm{~Hz}, 1 \mathrm{H}), 5.18(\mathrm{t}, J=9.0 \mathrm{~Hz}, 1 \mathrm{H}), 5.02(\mathrm{~d}, J=9.8 \mathrm{~Hz}, 1 \mathrm{H}), 4.58-4.50(\mathrm{~m}, 2 \mathrm{H})$, $4.45(\mathrm{t}, J=9.0 \mathrm{~Hz}, 2 \mathrm{H}), 4.31(\mathrm{~d}, J=9.8 \mathrm{~Hz}, 1 \mathrm{H}), 4.24(\mathrm{t}, J=6.3 \mathrm{~Hz}, 1 \mathrm{H}), 4.20-4.14(\mathrm{~m}, 1 \mathrm{H})$, 4.14-4.07(m, 1H), 3.94(d, $J=9.3 \mathrm{~Hz}, 1 \mathrm{H}), 3.87(\mathrm{t}, J=6.3 \mathrm{~Hz}, 1 \mathrm{H}), 2.15(\mathrm{~s}, 3 \mathrm{H}), 2.05(\mathrm{~s}, 3 \mathrm{H})$, 2.01(s, 6H); ${ }^{13} \mathrm{C}$ NMR $\left(126 \mathrm{MHz}, \mathrm{CDCl}_{3}\right)--\delta 172.98,171.05,170.60,170.46,170.22,156.45$, $143.86,143.73,141.55,141.50,128.02,127.34,125.20,125.16,120.25,101.90,77.23,71.07$ $70.89,69.71,68.92,67.44,67.16,61.46,54.26,47.31,20.85,20.83,20.81,20.76$.

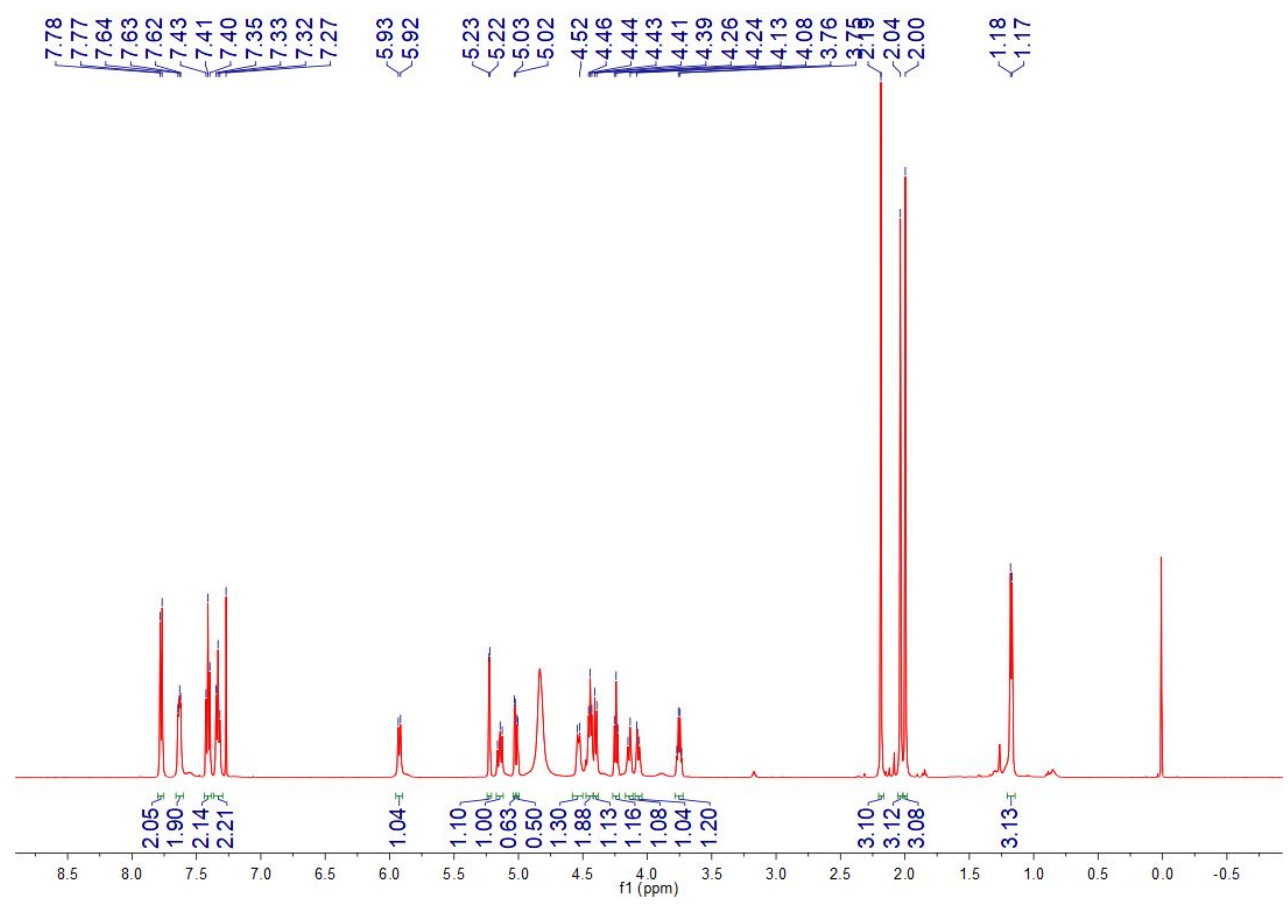




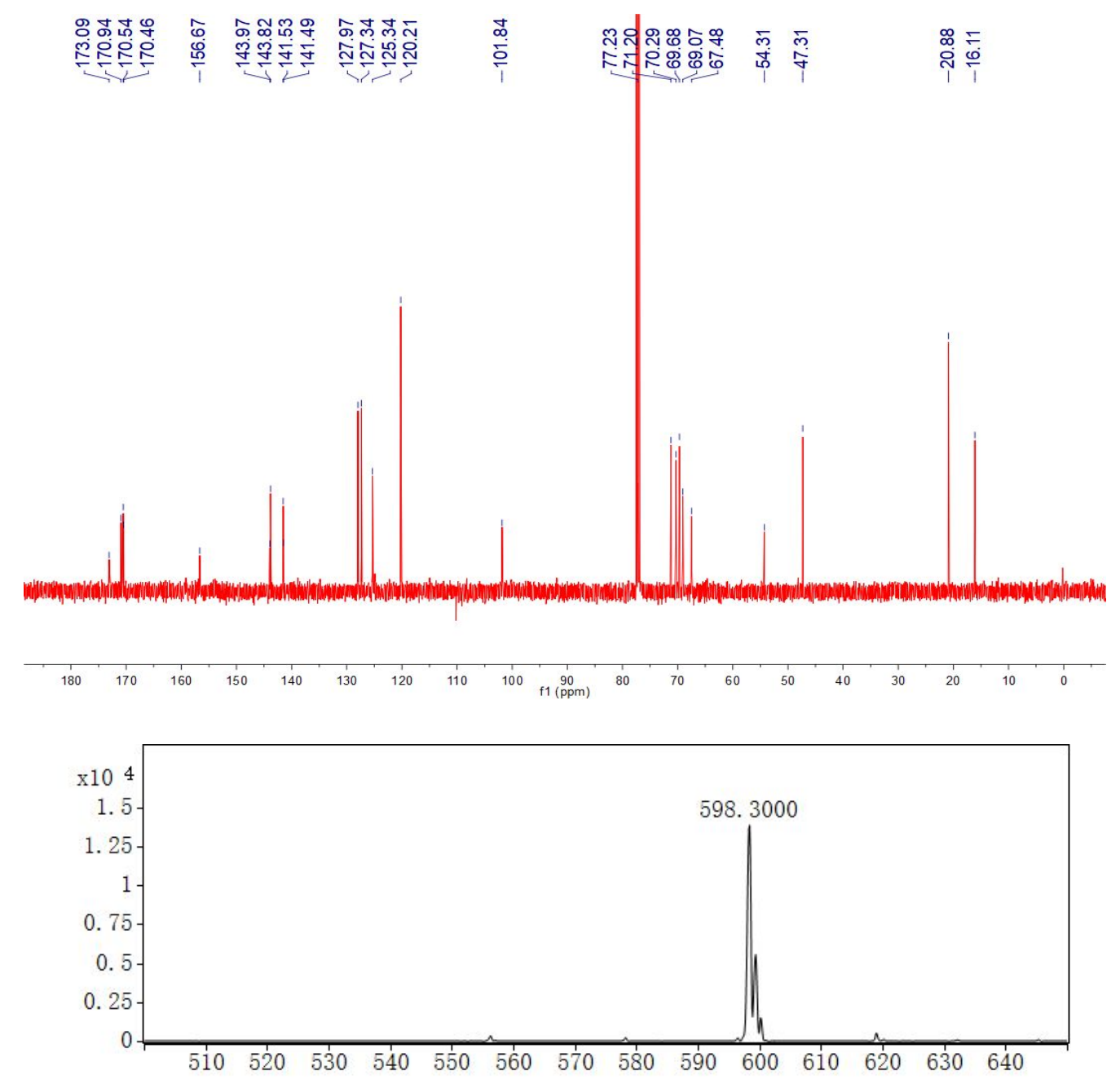

Figure S80. ${ }^{1} \mathrm{H}-\mathrm{NMR},{ }^{13} \mathrm{C}-\mathrm{NMR}$, ESI-MS of Fmoc-Ser[Fuc(AC $\left.\left.\mathbf{A C}_{3}\right) \boldsymbol{\beta}\right]-\mathbf{O H}\left({ }^{1} \mathrm{H}\right.$ NMR $(500 \mathrm{MHz}$, $\left.\mathrm{CDCl}_{3}\right)--\delta 7.77(\mathrm{~d}, J=7.5 \mathrm{~Hz}, 2 \mathrm{H}), 7.66-7.60(\mathrm{~m}, 2 \mathrm{H}), 7.41(\mathrm{t}, J=7.4 \mathrm{~Hz}, 2 \mathrm{H}), 7.33(\mathrm{t}, J=7.4 \mathrm{~Hz}$, $2 \mathrm{H}), 5.92(\mathrm{~d}, J=8.6 \mathrm{~Hz}, 1 \mathrm{H}), 5.23(\mathrm{~d}, J=3.3 \mathrm{~Hz}, 1 \mathrm{H}), 5.17-5.12(\mathrm{~m}, 1 \mathrm{H}), 5.03(\mathrm{~d}, J=3.4 \mathrm{~Hz}, 1 \mathrm{H})$, $5.01(\mathrm{~d}, J=3.4 \mathrm{~Hz}, 1 \mathrm{H}), 4.53(\mathrm{~d}, J=8.5 \mathrm{~Hz}, 1 \mathrm{H}), 4.44(\mathrm{t}, J=6.3 \mathrm{~Hz}, 2 \mathrm{H}), 4.40(\mathrm{~d}, J=8.0 \mathrm{~Hz}, 1 \mathrm{H})$, $4.24(\mathrm{t}, J=6.9 \mathrm{~Hz}, 1 \mathrm{H}), 4.14(\mathrm{~d}, J=8.5 \mathrm{~Hz}, 1 \mathrm{H}), 4.07(\mathrm{~d}, J=10.2 \mathrm{~Hz}, 1 \mathrm{H}), 3.75(\mathrm{q}, J=6.2 \mathrm{~Hz}, 1 \mathrm{H})$, 2.19(s, 3H), 2.04(s, 3H), 2.00(s, 3H), 1.17(d, $J=6.3 \mathrm{~Hz}, 3 \mathrm{H}) ;{ }^{13} \mathrm{C}$ NMR $\left(126 \mathrm{MHz}, \mathrm{CDCl}_{3}\right)--\delta$ $173.09,170.94,170.54,170.46,156.67,143.97,143.82,141.53,141.49,127.97,127.34,127.32$, $125.34,120.21,101.84,77.23,71.20,70.35,70.29,69.68,69.07,67.48,54.31,47.31,20.88$, 20.83, 16.11.) 

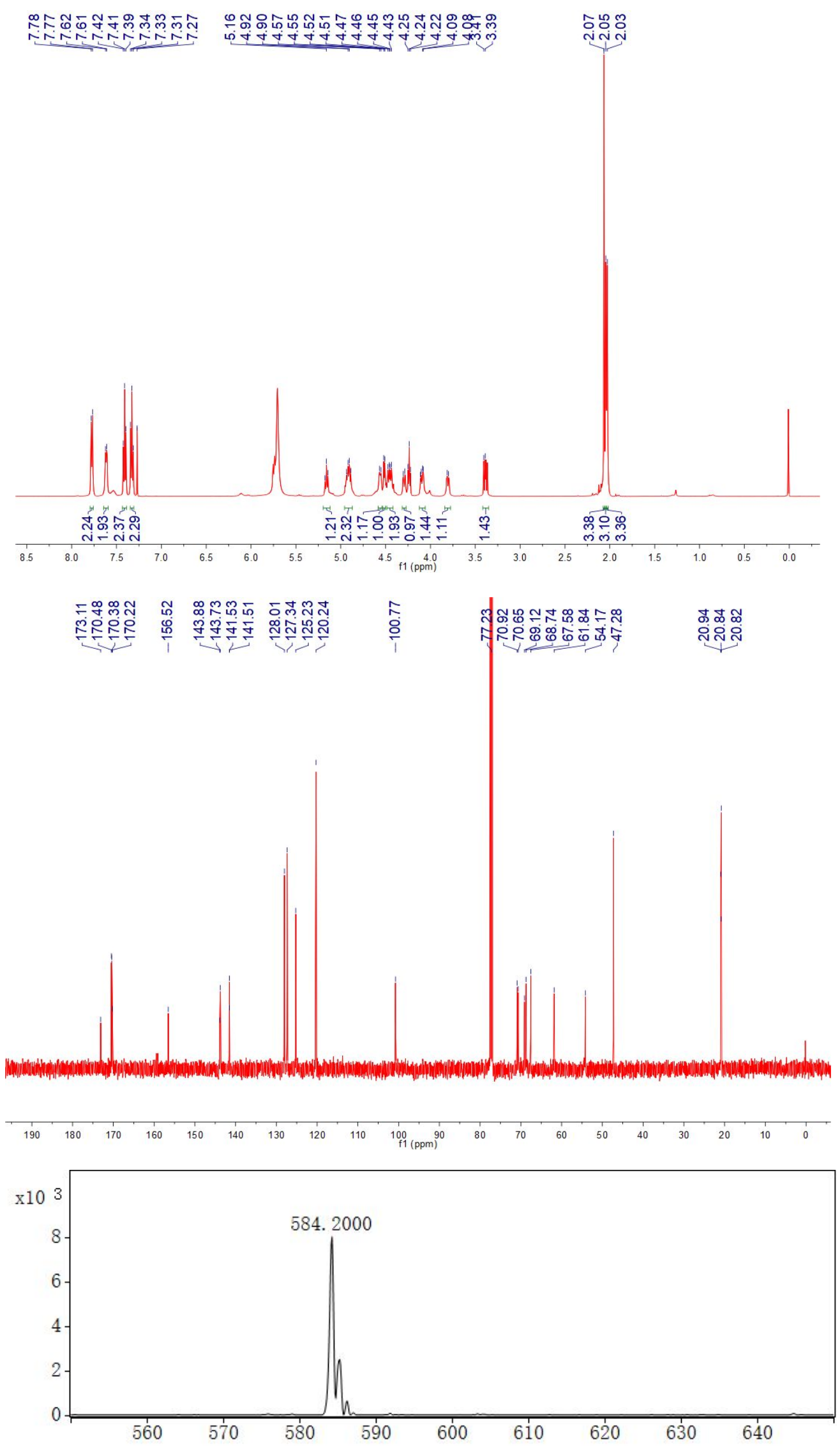

Figure S81. ${ }^{1} \mathrm{H}-\mathrm{NMR},{ }^{13} \mathrm{C}-\mathrm{NMR}$, ESI-MS of Fmoc-Ser[D-Xyl(AC $\left.\left.\mathbf{A}\right) \boldsymbol{\text { F }}\right]-\mathbf{O H}\left({ }^{1} \mathrm{H}\right.$ NMR $(500 \mathrm{MHz}$, 
$\left.\mathrm{CDCl}_{3}\right)--\delta 7.77(\mathrm{~d}, J=7.5 \mathrm{~Hz}, 2 \mathrm{H}), 7.62(\mathrm{~d}, J=6.4 \mathrm{~Hz}, 2 \mathrm{H}), 7.41(\mathrm{t}, J=7.4 \mathrm{~Hz}, 2 \mathrm{H}), 7.33(\mathrm{t}, J=$ $7.4 \mathrm{~Hz}, 2 \mathrm{H}), 5.16(\mathrm{t}, J=8.1 \mathrm{~Hz}, 1 \mathrm{H}), 4.91(\mathrm{dd}, J=15.1,8.2 \mathrm{~Hz}, 2 \mathrm{H}), 4.56(\mathrm{~d}, J=7.8 \mathrm{~Hz}, 1 \mathrm{H})$, $4.51(\mathrm{~d}, J=6.1 \mathrm{~Hz}, 1 \mathrm{H}), 4.45(\mathrm{dd}, J=12.7,7.0 \mathrm{~Hz}, 2 \mathrm{H}), 4.29(\mathrm{~d}, J=9.8 \mathrm{~Hz}, 1 \mathrm{H}), 4.09(\mathrm{dd}, J=11.9$, $4.7 \mathrm{~Hz}, 1 \mathrm{H}), 3.81(\mathrm{~d}, J=7.3 \mathrm{~Hz}, 1 \mathrm{H}), 3.40(\mathrm{~d}, J=8.1 \mathrm{~Hz}, 1 \mathrm{H}), 2.07(\mathrm{~s}, 3 \mathrm{H}), 2.05(\mathrm{~s}, 3 \mathrm{H}), 2.03(\mathrm{~s}$, $3 \mathrm{H}) ;{ }^{13} \mathrm{C}$ NMR $\left(126 \mathrm{MHz}, \mathrm{CDCl}_{3}\right)--\delta 173.11,170.48,170.38,170.22,156.52,143.88,143.73$, $141.53,141.51,128.01,127.34,125.23,120.24,100.77,77.23,70.92,70.65,69.12,68.74,67.58$, $61.84,54.17,47.28,20.94,20.84,20.82$.

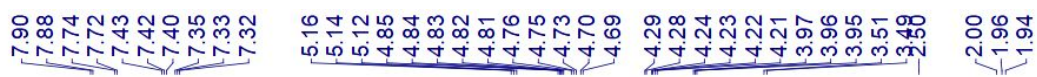

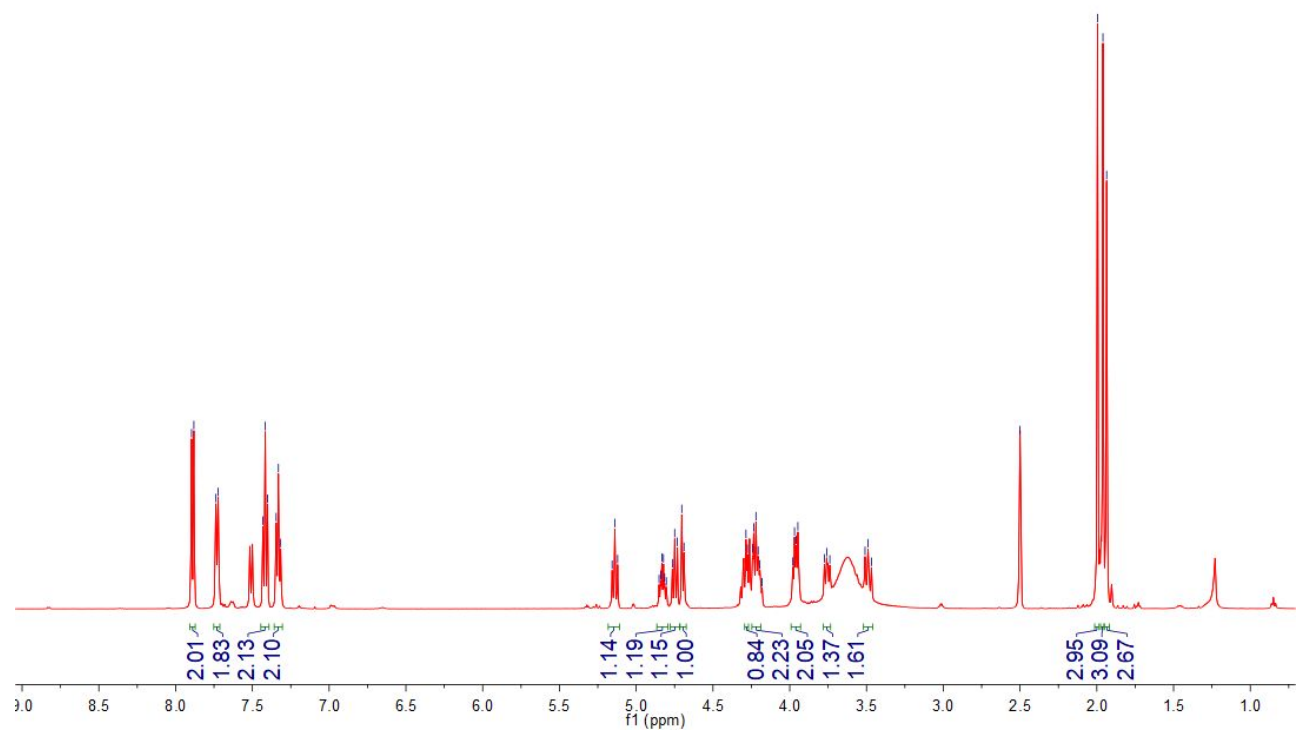




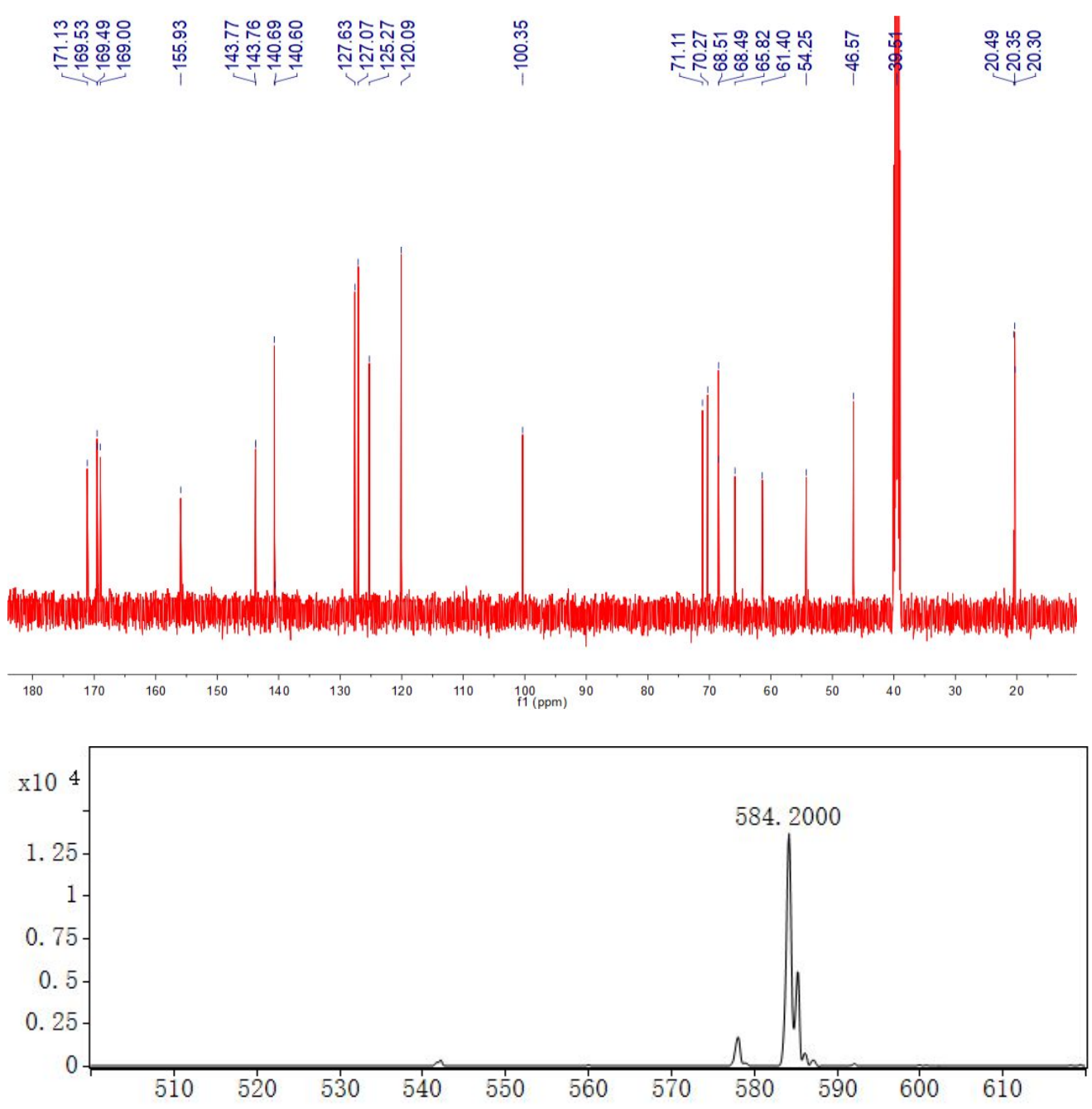

Figure S82. ${ }^{1} \mathrm{H}-\mathrm{NMR},{ }^{13} \mathrm{C}-\mathrm{NMR}$, ESI-MS of Fmoc-Ser [L-Xyl(AC $\left.\left.\mathbf{A}\right) \boldsymbol{B}\right]-\mathbf{O H}\left({ }^{1} \mathrm{H}\right.$ NMR $(500 \mathrm{MHz}$, DMSO-d $\left.\mathrm{d}_{6}\right)--\delta 7.89(\mathrm{~d}, J=7.5 \mathrm{~Hz}, 2 \mathrm{H}), 7.73(\mathrm{~d}, J=7.4 \mathrm{~Hz}, 2 \mathrm{H}), 7.42(\mathrm{t}, J=7.4 \mathrm{~Hz}, 2 \mathrm{H}), 7.33(\mathrm{t}, J$ $=7.4 \mathrm{~Hz}, 2 \mathrm{H}), 5.14(\mathrm{t}, J=9.0 \mathrm{~Hz}, 1 \mathrm{H}), 4.83(\mathrm{td}, J=9.2,5.4 \mathrm{~Hz}, 1 \mathrm{H}), 4.78-4.72(\mathrm{~m}, 1 \mathrm{H}), 4.70(\mathrm{~d}, J$ $=7.3 \mathrm{~Hz}, 1 \mathrm{H}), 4.28(\mathrm{~d}, J=4.6 \mathrm{~Hz}, 1 \mathrm{H}), 4.25-4.19(\mathrm{~m}, 2 \mathrm{H}), 3.96(\mathrm{dd}, J=11.0,5.3 \mathrm{~Hz}, 2 \mathrm{H})$, 3.78-3.73 (m, 1H), 3.52-3.46 (m, 2H), 2.00(s, 3H), 1.96(s, 3H), 1.94(s, 3H); ${ }^{13} \mathrm{C}$ NMR (126 MHz, DMSO-d $\left.\mathrm{d}_{6}\right)--\delta 171.13,169.53,169.49,169.00,155.93,143.77,143.76,140.69,140.60,127.63$, $127.07,125.27,120.09,100.35,71.11,70.27,68.51,68.49,65.82,61.40,54.25,46.57,39.51$, $20.49,20.35,20.30$.) 


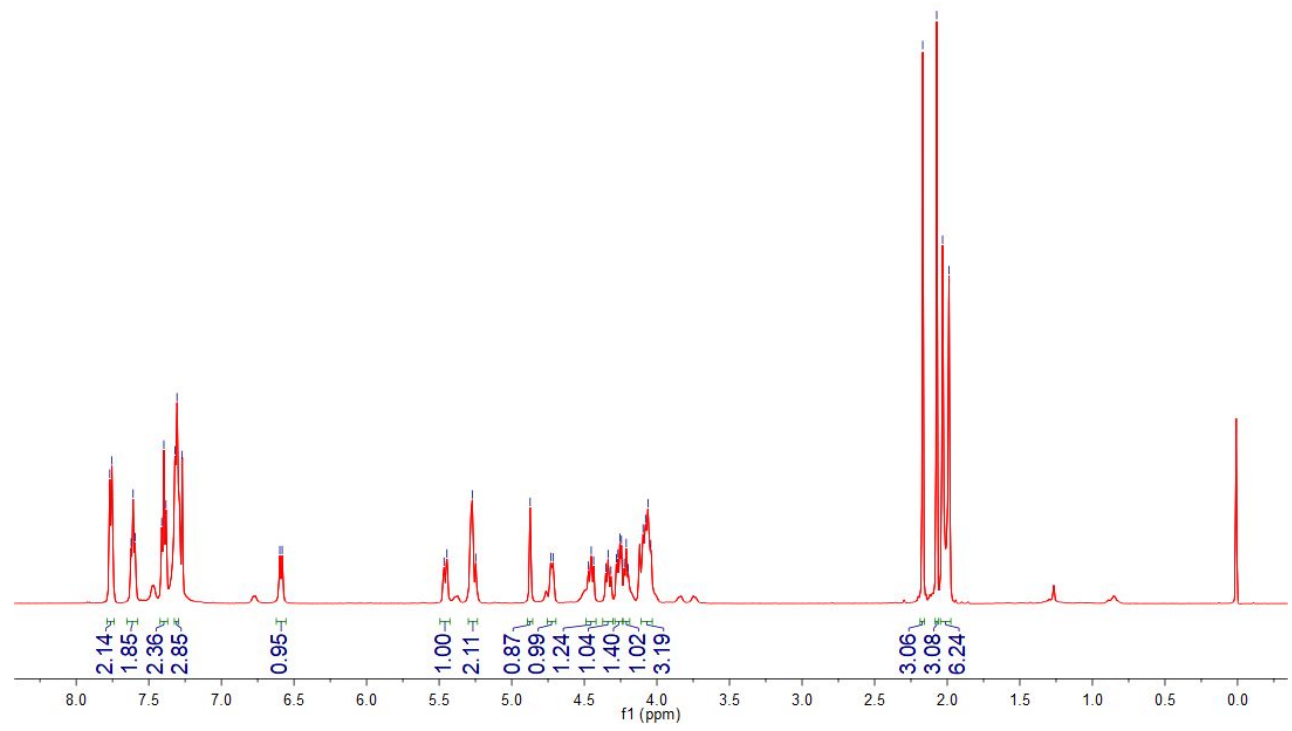

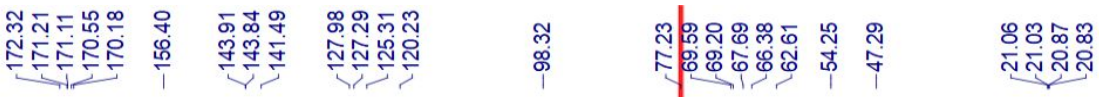
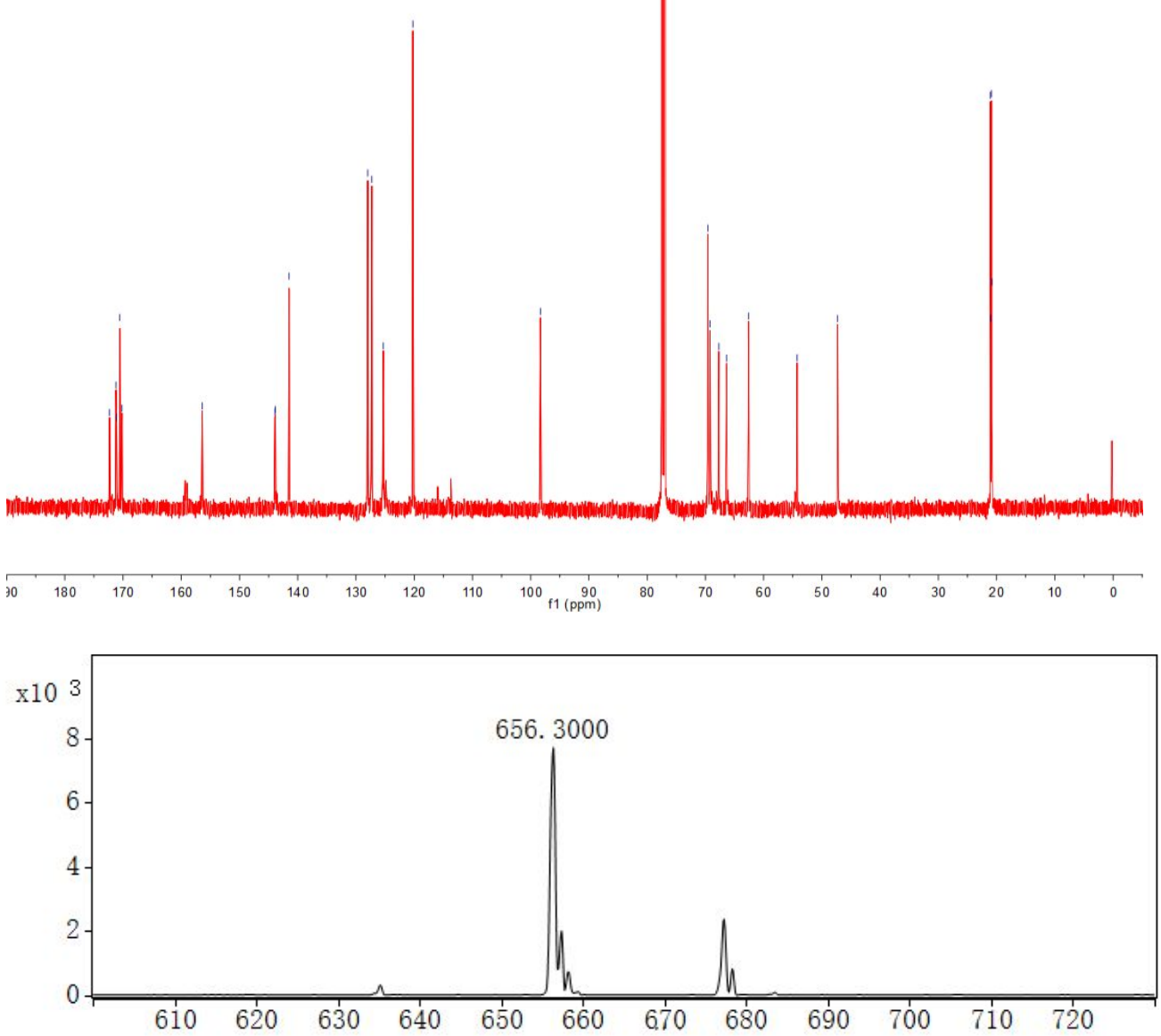

Figure S83. ${ }^{1} \mathrm{H}-\mathrm{NMR},{ }^{13} \mathrm{C}-\mathrm{NMR}$, ESI-MS of Fmoc-Ser[Man( $\left.\left.\mathbf{A C} \mathbf{C}_{4}\right) \boldsymbol{\alpha}\right]-\mathbf{O H}\left({ }^{1} \mathrm{H}\right.$ NMR $(500 \mathrm{MHz}$, 
$\left.\mathrm{CDCl}_{3}\right)--\delta 7.76(\mathrm{~d}, J=7.3 \mathrm{~Hz}, 2 \mathrm{H}), 7.61(\mathrm{t}, J=6.8 \mathrm{~Hz}, 2 \mathrm{H}), 7.40(\mathrm{t}, J=7.3 \mathrm{~Hz}, 2 \mathrm{H}), 7.31(\mathrm{~d}, J=$ $6.7 \mathrm{~Hz}, 3 \mathrm{H}), 6.59(\mathrm{~d}, J=8.3 \mathrm{~Hz}, 1 \mathrm{H}), 5.46(\mathrm{~d}, J=9.9 \mathrm{~Hz}, 1 \mathrm{H}), 5.26(\mathrm{~d}, J=11.7 \mathrm{~Hz}, 2 \mathrm{H}), 4.87(\mathrm{~s}$, 1H), 4.72(d, $J=7.8 \mathrm{~Hz}, 1 \mathrm{H}), 4.49-4.42(\mathrm{~m}, 1 \mathrm{H}), 4.37-4.30(\mathrm{~m}, 1 \mathrm{H}), 4.26(\mathrm{dd}, J=12.1,5.5 \mathrm{~Hz}$, 1H), 4.21(t, $J=7.1 \mathrm{~Hz}, 1 \mathrm{H}), 4.07(\mathrm{dd}, J=17.5,9.0 \mathrm{~Hz}, 3 \mathrm{H}), 2.17(\mathrm{~s}, 3 \mathrm{H}), 2.07(\mathrm{~s}, 3 \mathrm{H}), 2.01(\mathrm{~d}, J=$ $22.2 \mathrm{~Hz}, 6 \mathrm{H}) ;{ }^{13} \mathrm{C}$ NMR $\left(126 \mathrm{MHz}, \mathrm{CDCl}_{3}\right)--\delta$ 172.32, 171.21, 171.11, 170.55, 170.18, 156.40, $143.91,141.49,127.98,127.29,125.38,120.23,98.32,77.23,69.59,69.20,69.12,67.69,66.38$, $62.61,54.25,47.29,21.06,21.03,20.87,20.83$.

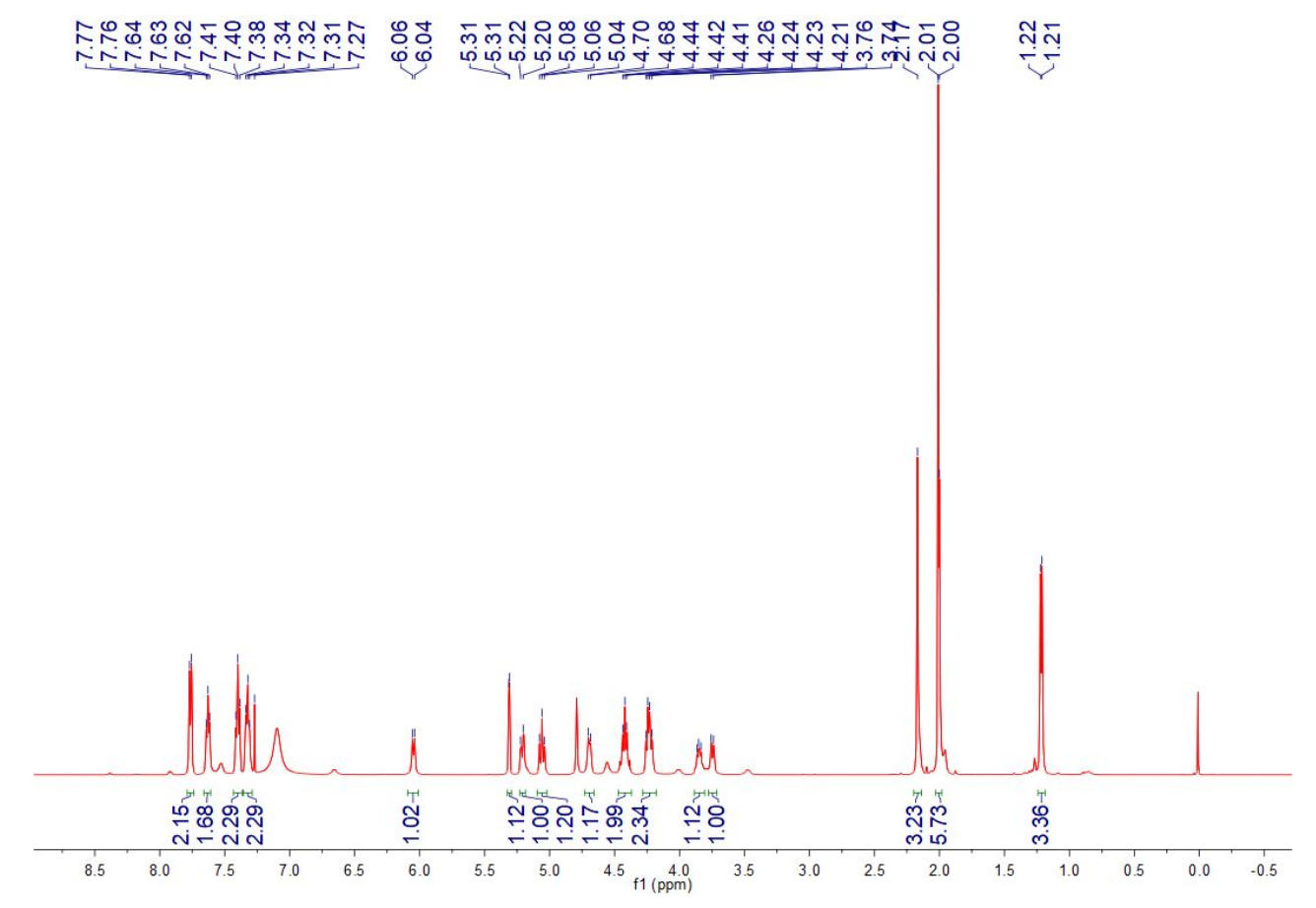




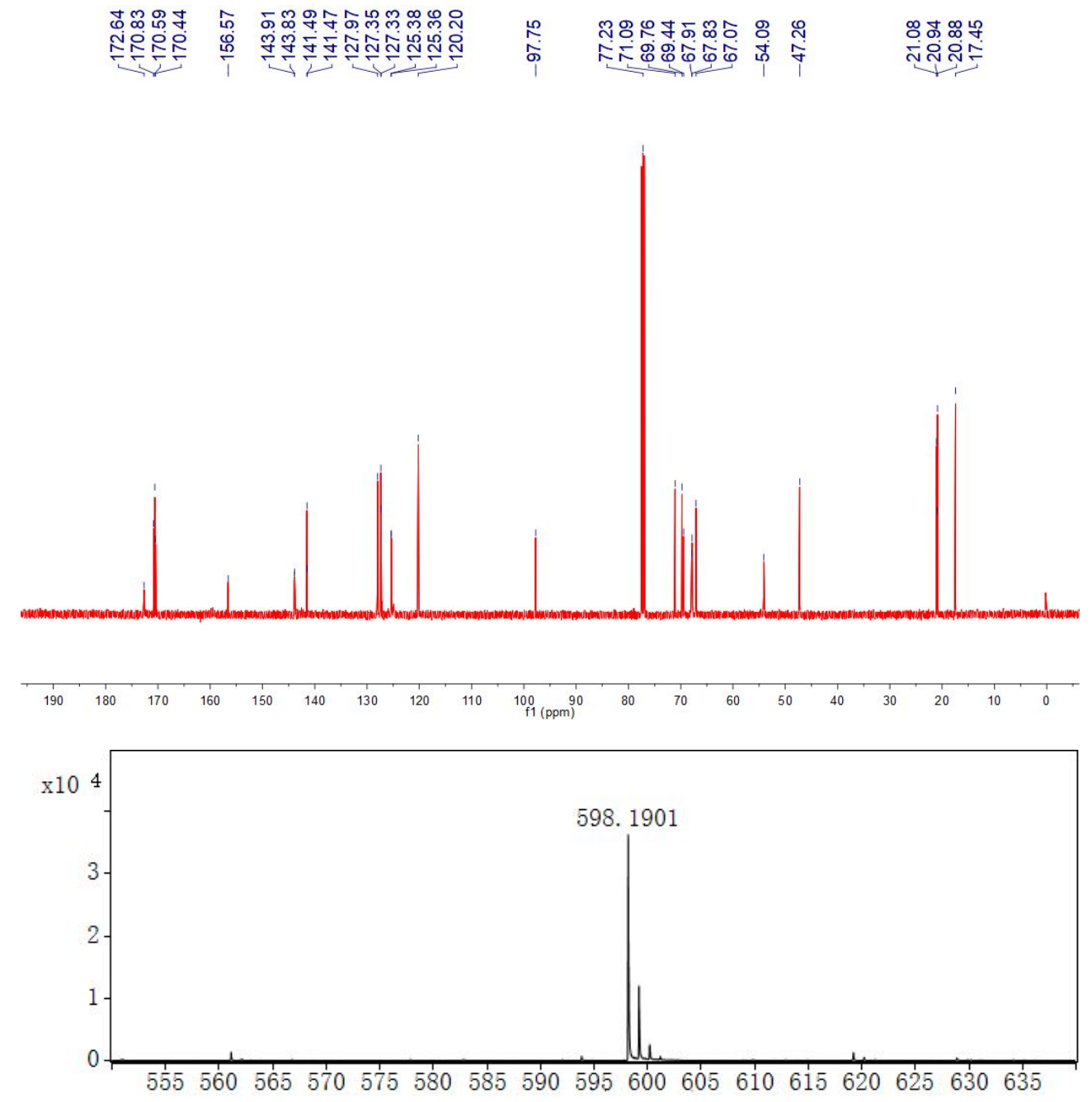

Figure S84. ${ }^{1} \mathrm{H}-\mathrm{NMR},{ }^{13} \mathrm{C}-\mathrm{NMR}$, ESI-MS of Fmoc-Ser[Rha(AC $\left.\left.\mathbf{A C}_{4}\right) \boldsymbol{\alpha}\right]-\mathbf{O H}\left({ }^{1} \mathrm{H}\right.$ NMR $(500 \mathrm{MHz}$, $\left.\mathrm{CDCl}_{3}\right)--\delta 7.76(\mathrm{~d}, J=7.4 \mathrm{~Hz}, 2 \mathrm{H}), 7.63(\mathrm{t}, J=6.4 \mathrm{~Hz}, 2 \mathrm{H}), 7.40(\mathrm{t}, J=7.3 \mathrm{~Hz}, 2 \mathrm{H}), 7.32(\mathrm{t}, J=7.1$ $\mathrm{Hz}, 2 \mathrm{H}), 6.05(\mathrm{~d}, J=8.3 \mathrm{~Hz}, 1 \mathrm{H}), 5.31(\mathrm{~d}, J=1.6 \mathrm{~Hz}, 1 \mathrm{H}), 5.21(\mathrm{~d}, J=10.0 \mathrm{~Hz}, 1 \mathrm{H}), 5.06(\mathrm{t}, J=9.9$ $\mathrm{Hz}, 1 \mathrm{H}), 4.69(\mathrm{~d}, J=8.1 \mathrm{~Hz}, 1 \mathrm{H}), 4.42(\mathrm{t}, J=7.8 \mathrm{~Hz}, 2 \mathrm{H}), 4.24(\mathrm{dd}, J=15.0,8.1 \mathrm{~Hz}, 2 \mathrm{H})$, 3.89-3.81(m, 1H), 3.75(d, $J=9.4 \mathrm{~Hz}, 1 \mathrm{H}), 2.17(\mathrm{~s}, 3 \mathrm{H}), 2.00(\mathrm{~d}, J=4.5 \mathrm{~Hz}, 6 \mathrm{H}), 1.22(\mathrm{~d}, J=6.1$ $\mathrm{Hz}, 3 \mathrm{H}) ;{ }^{13} \mathrm{C} \mathrm{NMR}\left(126 \mathrm{MHz}, \mathrm{CDCl}_{3}\right)--\delta 172.64,170.83,170.59,170.44,156.57,143.91$, $143.83,141.49,141.47,127.97,127.35,127.33,125.38,125.36,120.20,97.75,77.23,71.09$, $69.76,69.44,67.91,67.83,67.07,54.09,47.26,21.08,20.94,20.88,17.45$. 


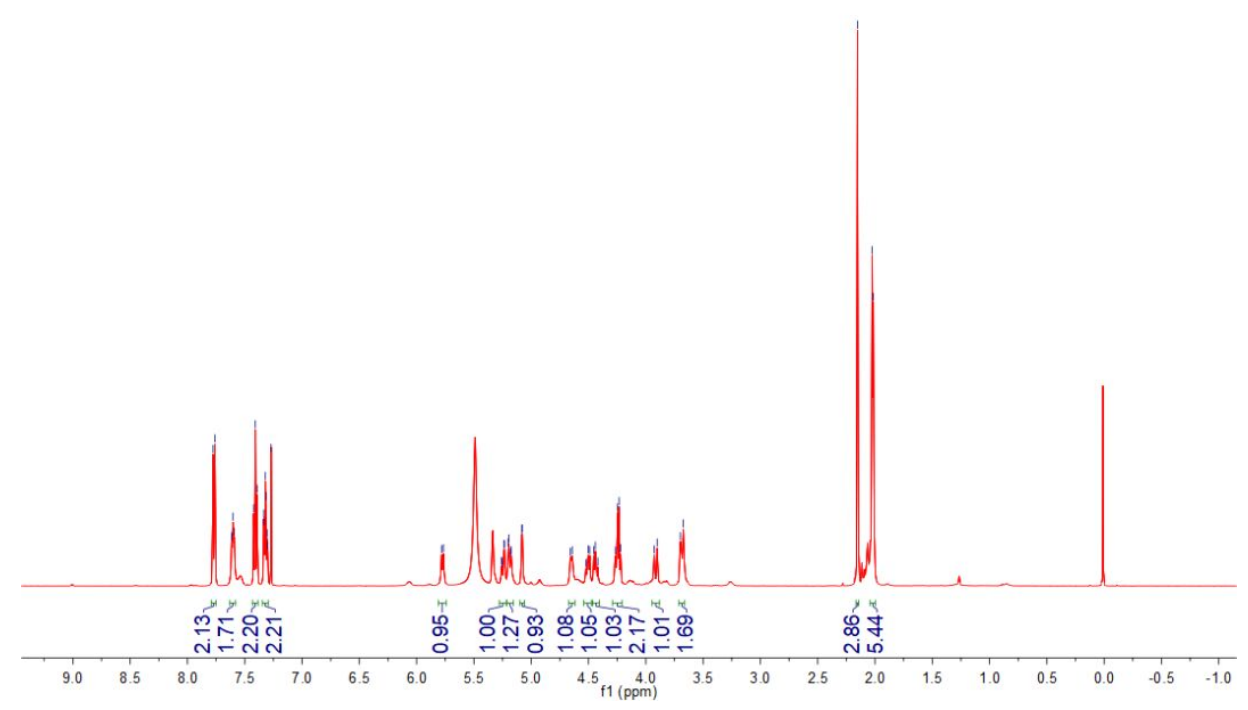

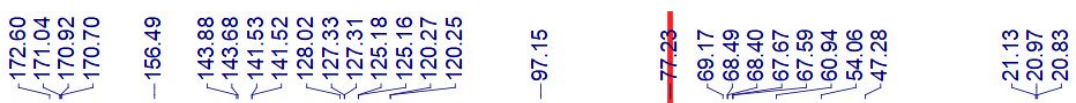
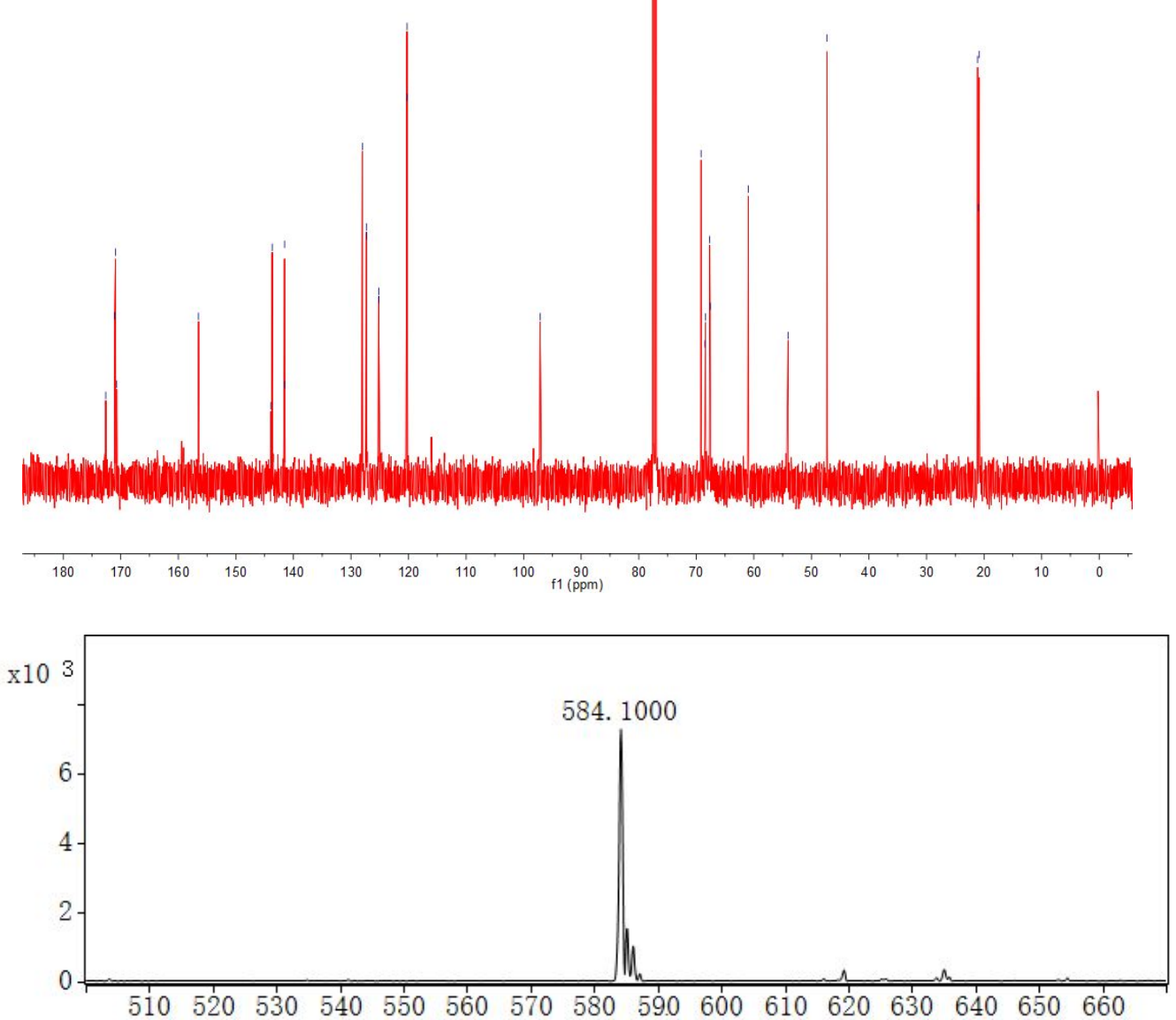

Figure S85. ${ }^{1} \mathrm{H}-\mathrm{NMR},{ }^{13} \mathrm{C}-\mathrm{NMR}$, ESI-MS of Fmoc-Ser[D-Arb($\left.\left(\mathbf{A C}_{4}\right) \boldsymbol{\alpha}\right]-\mathrm{OH}\left({ }^{1} \mathrm{H}\right.$ NMR $(500$ 
$\left.\mathrm{MHz}, \mathrm{CDCl}_{3}\right)--\delta 7.77(\mathrm{~d}, J=7.5 \mathrm{~Hz}, 2 \mathrm{H}), 7.63-7.58(\mathrm{~m}, 2 \mathrm{H}), 7.41(\mathrm{t}, J=7.5 \mathrm{~Hz}, 2 \mathrm{H}), 7.32(\mathrm{td}, J=$ 7.4, $2.6 \mathrm{~Hz}, 2 \mathrm{H}), 5.77(\mathrm{~d}, J=8.4 \mathrm{~Hz}, 1 \mathrm{H}), 5.25(\mathrm{dd}, J=10.8,2.7 \mathrm{~Hz}, 1 \mathrm{H}), 5.19(\mathrm{dd}, J=10.6,2.9$ $\mathrm{Hz}, 1 \mathrm{H}), 5.08(\mathrm{~d}, J=2.7 \mathrm{~Hz}, 1 \mathrm{H}), 4.65(\mathrm{~d}, J=8.2 \mathrm{~Hz}, 1 \mathrm{H}), 4.54-4.48(\mathrm{~m}, 1 \mathrm{H}), 4.46-4.41(\mathrm{~m}, 1 \mathrm{H})$, $4.24(\mathrm{dd}, J=14.5,7.9 \mathrm{~Hz}, 2 \mathrm{H}), 3.91(\mathrm{~d}, J=13.1 \mathrm{~Hz}, 1 \mathrm{H}), 3.69(\mathrm{~d}, J=12.8 \mathrm{~Hz}, 2 \mathrm{H}), 2.15(\mathrm{~s}, 3 \mathrm{H})$, $2.02(\mathrm{~d}, J=5.3 \mathrm{~Hz}, 6 \mathrm{H}) ;{ }^{13} \mathrm{C} \mathrm{NMR}\left(126 \mathrm{MHz}, \mathrm{CDCl}_{3}\right)--\delta 172.60,171.04,170.92,170.70,156.49$, $143.88,143.68,141.53,141.52,128.02,127.33,127.31,125.18,125.16,120.27,120.25,97.15$, $77.23,69.17,68.49,68.40,67.67,67.59,60.94,54.06,47.28,21.13,20.97,20.83$.

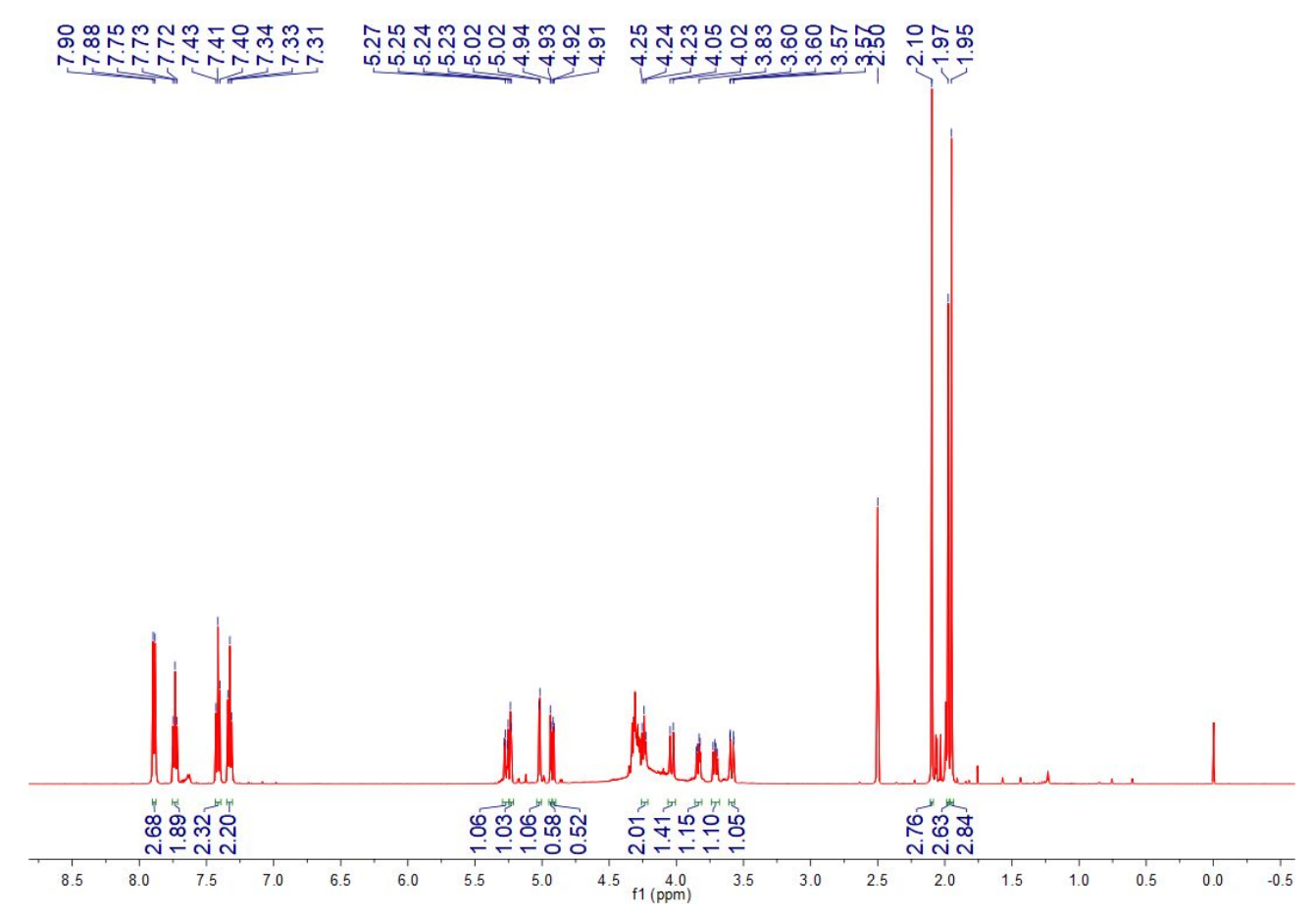




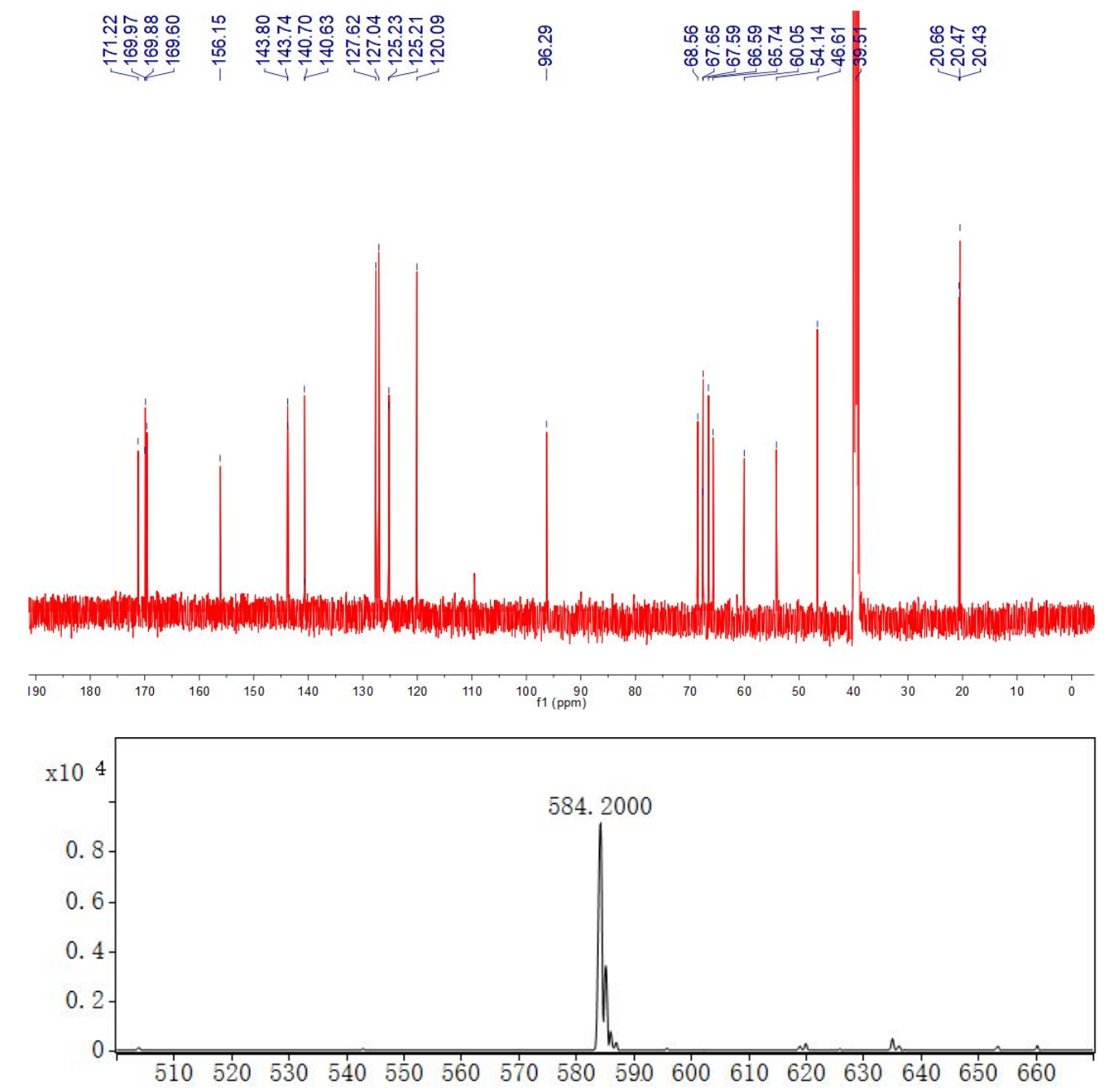

Figure S86. ${ }^{1} \mathrm{H}-\mathrm{NMR},{ }^{13} \mathrm{C}-\mathrm{NMR}$, ESI-MS of Fmoc-Ser[L-Arb(AC $\left.\left.\mathbf{A C}_{4}\right) \boldsymbol{\alpha}\right]-\mathrm{OH}\left({ }^{1} \mathrm{H}\right.$ NMR $(500$ MHz, DMSO-d $\left.{ }_{6}\right)--\delta 7.89(\mathrm{~d}, J=7.2 \mathrm{~Hz}, 3 \mathrm{H}), 7.73(\mathrm{t}, J=7.7 \mathrm{~Hz}, 2 \mathrm{H}), 7.41(\mathrm{t}, J=7.4 \mathrm{~Hz}, 2 \mathrm{H})$, $7.33(\mathrm{t}, J=7.4 \mathrm{~Hz}, 2 \mathrm{H}), 5.27(\mathrm{dd}, J=10.7,3.6 \mathrm{~Hz}, 1 \mathrm{H}), 5.23(\mathrm{~d}, J=3.6 \mathrm{~Hz}, 1 \mathrm{H}), 5.02(\mathrm{~d}, J=3.6 \mathrm{~Hz}$ $1 \mathrm{H}), 4.93(\mathrm{~d}, J=3.6 \mathrm{~Hz}, 1 \mathrm{H}), 4.91(\mathrm{~d}, J=3.6 \mathrm{~Hz}, 1 \mathrm{H}), 4.26-4.21(\mathrm{~m}, 2 \mathrm{H}), 4.03(\mathrm{~d}, J=12.5 \mathrm{~Hz}, 1 \mathrm{H})$, $3.84(\mathrm{dd}, J=10.3,3.8 \mathrm{~Hz}, 1 \mathrm{H}), 3.71(\mathrm{dd}, J=10.3,6.3 \mathrm{~Hz}, 1 \mathrm{H}), 3.59(\mathrm{dd}, J=13.1,1.6 \mathrm{~Hz}, 1 \mathrm{H})$, 2.10(s, 3H), 1.97(s, 3H), 1.95(s, 3H); ${ }^{13} \mathrm{C}$ NMR (126 MHz, DMSO-d $\left.\mathrm{d}_{6}\right)--\delta$ 171.22, 169.97, $169.88,169.60,156.15,143.80,143.74,140.70,140.63,127.62,127.04,125.23,125.21,120.09$, $96.29,68.56,67.65,67.59,66.59,65.74,60.05,54.14,46.61,39.51,20.66,20.47,20.43$. 


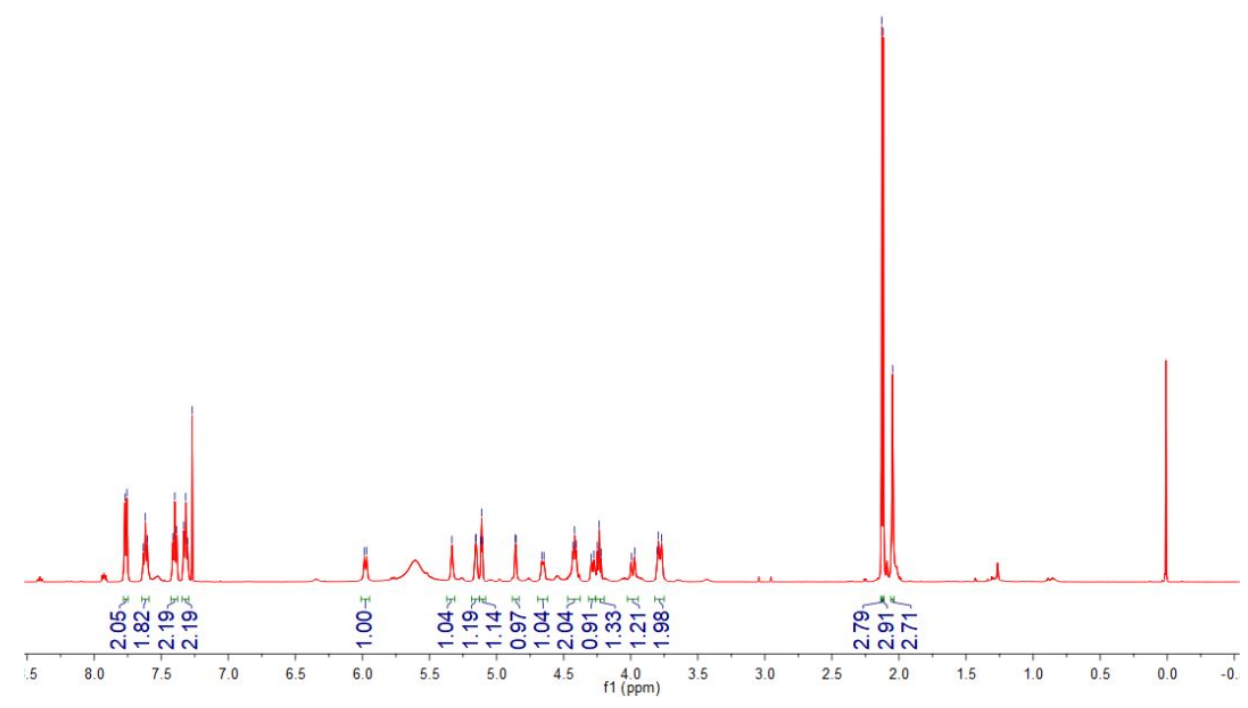

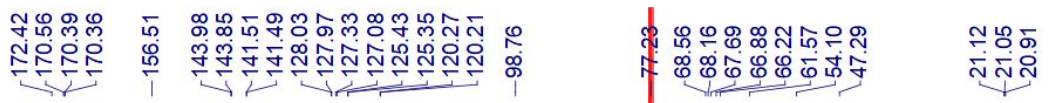
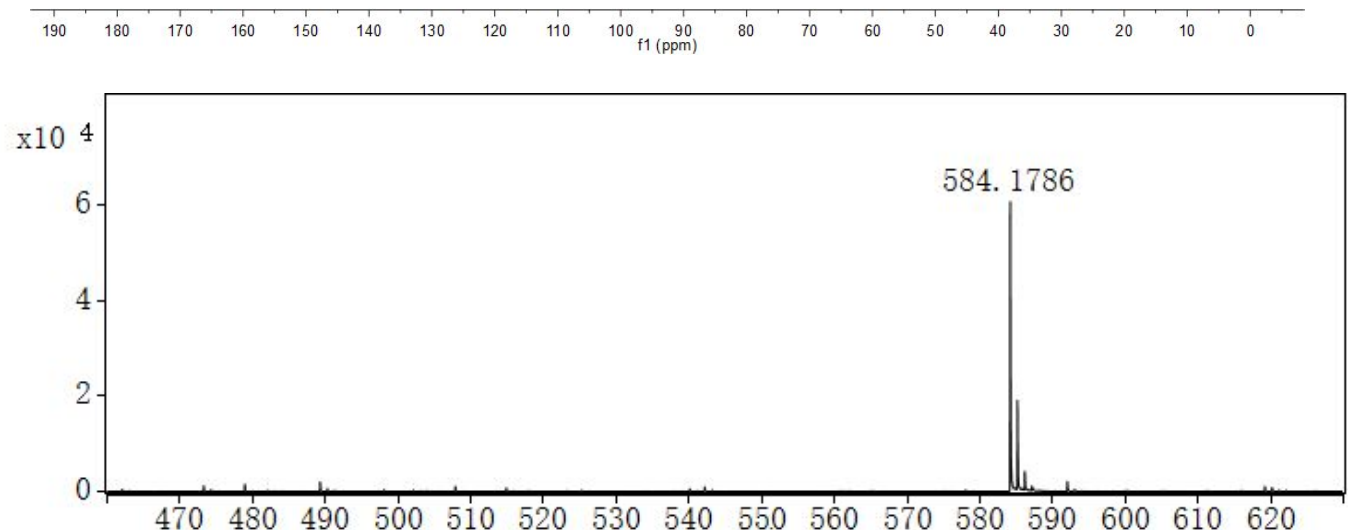

Figure S87. ${ }^{1} \mathrm{H}-\mathrm{NMR},{ }^{13} \mathrm{C}-\mathrm{NMR}$, ESI-MS of Fmoc-Ser[D-Rib(AC 4$\left.) \boldsymbol{\alpha}\right]-\mathbf{O H}\left({ }^{1} \mathrm{H} \mathrm{NMR}(500 \mathrm{MHz}\right.$, 
$\left.\mathrm{CDCl}_{3}\right)--\delta 7.76(\mathrm{~d}, J=7.4 \mathrm{~Hz}, 2 \mathrm{H}), 7.62(\mathrm{t}, J=7.6 \mathrm{~Hz}, 2 \mathrm{H}), 7.40(\mathrm{t}, J=7.2 \mathrm{~Hz}, 2 \mathrm{H}), 7.32(\mathrm{t}, J=7.3$ $\mathrm{Hz}, 2 \mathrm{H}), 5.98(\mathrm{~d}, J=8.3 \mathrm{~Hz}, 1 \mathrm{H}), 5.33(\mathrm{~s}, 1 \mathrm{H}), 5.15(\mathrm{~d}, J=2.5 \mathrm{~Hz}, 1 \mathrm{H}), 5.11(\mathrm{t}, J=3.3 \mathrm{~Hz}, 1 \mathrm{H})$, $4.86(\mathrm{~d}, J=2.7 \mathrm{~Hz}, 1 \mathrm{H}), 4.66(\mathrm{~d}, J=8.1 \mathrm{~Hz}, 1 \mathrm{H}), 4.47-4.38(\mathrm{~m}, 2 \mathrm{H}), 4.28(\mathrm{~d}, J=9.8 \mathrm{~Hz}, 1 \mathrm{H}), 4.24(\mathrm{t}$, $J=7.0 \mathrm{~Hz}, 1 \mathrm{H}), 3.98(\mathrm{~d}, J=12.4 \mathrm{~Hz}, 1 \mathrm{H}), 3.82-3.75(\mathrm{~m}, 2 \mathrm{H}), 2.13(\mathrm{~s}, 3 \mathrm{H}), 2.12(\mathrm{~s}, 3 \mathrm{H}), 2.05(\mathrm{~s}, 3 \mathrm{H})$; ${ }^{13} \mathrm{C}$ NMR $\left(126 \mathrm{MHz}, \mathrm{CDCl}_{3}\right)--\delta 172.42,170.56,170.39,170.36,156.51,143.98,143.85,141.51$, $141.49,128.03,127.97,127.33,127.08,125.43,125.35,120.27,120.21,98.76,77.23,68.56$, $68.16,67.69,66.88,66.22,61.57,54.10,47.29,21.12,21.05,20.91$.

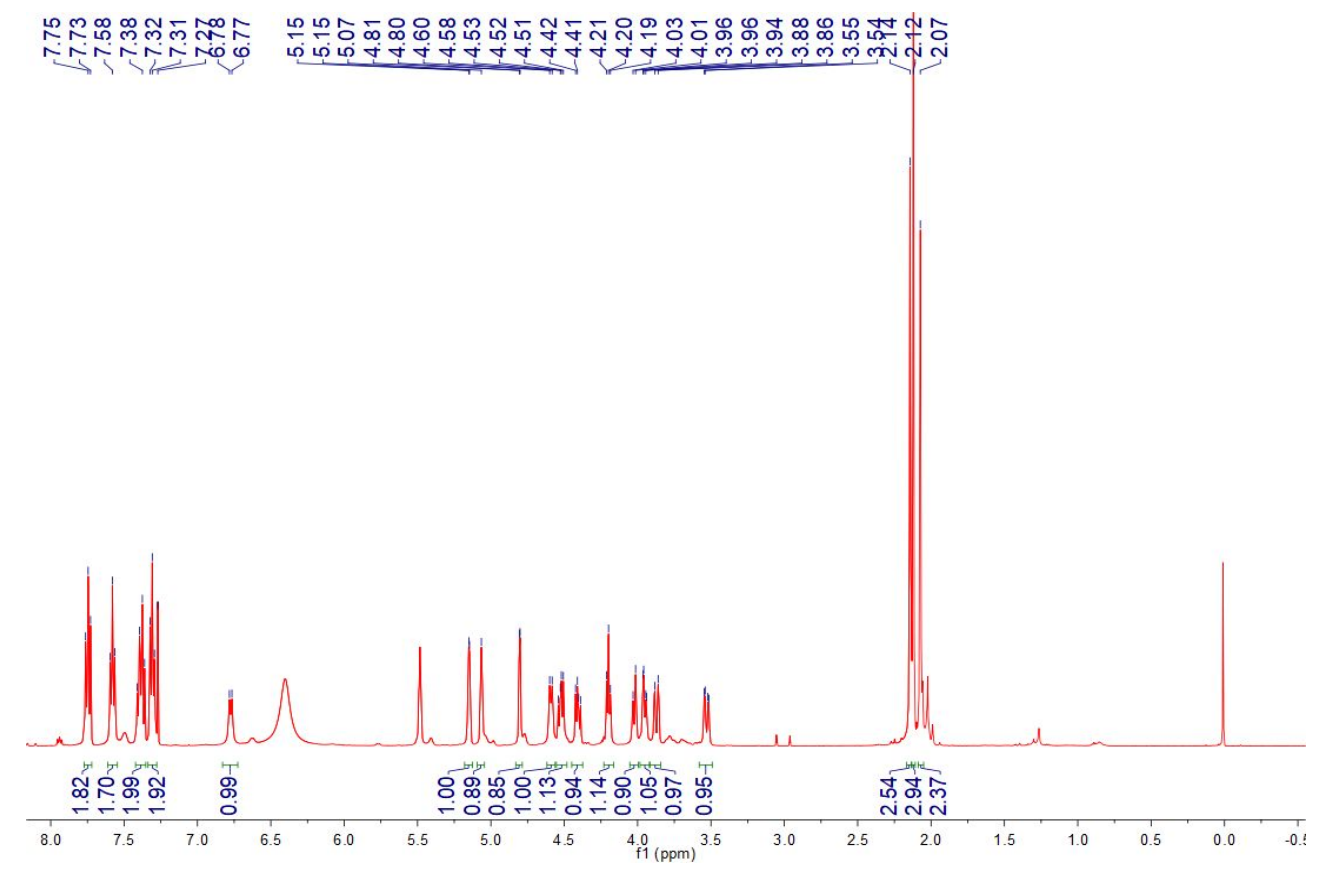



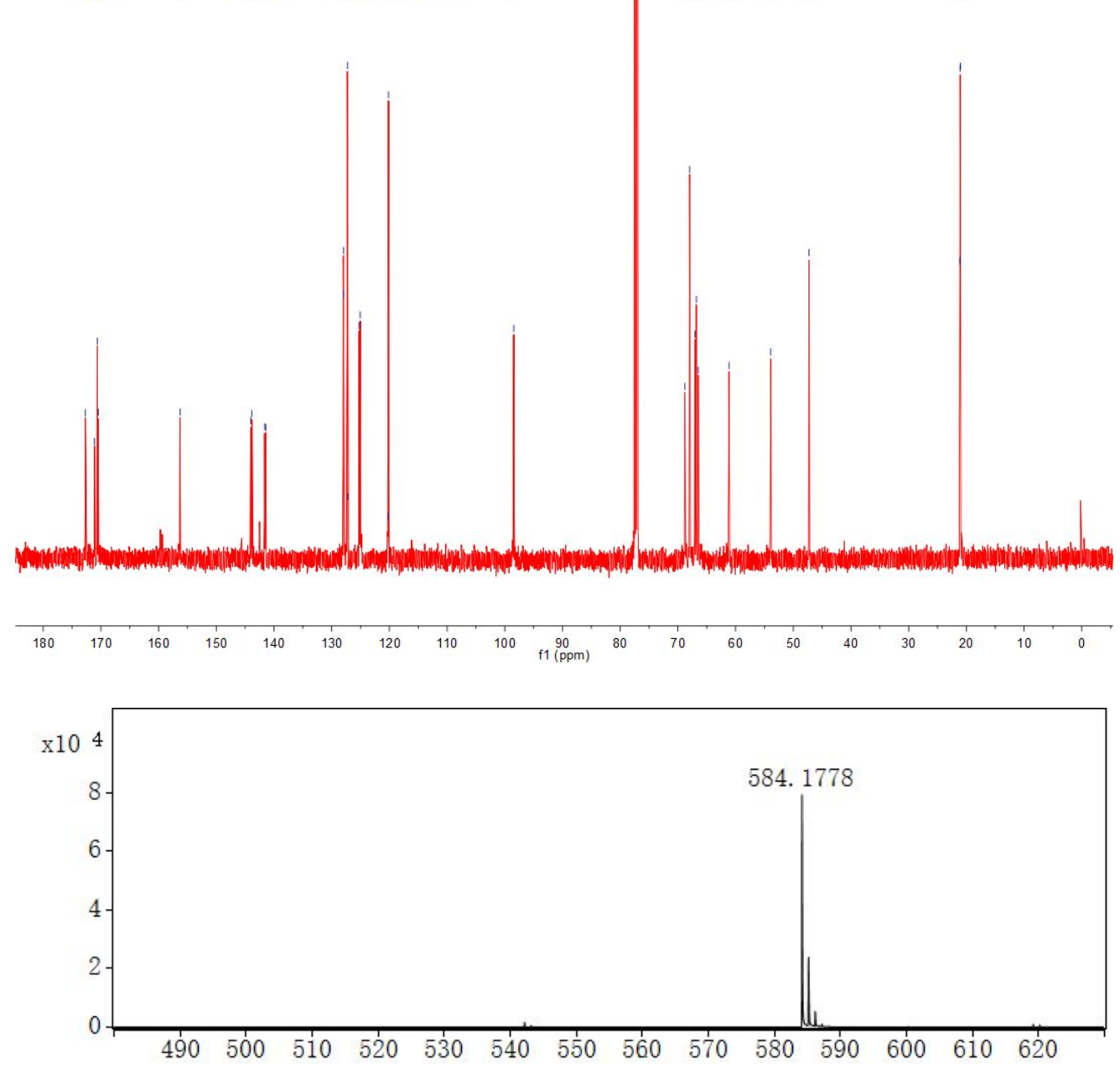

Figure S88. ${ }^{1} \mathrm{H}-\mathrm{NMR},{ }^{13} \mathrm{C}-\mathrm{NMR}$, ESI-MS of Fmoc-Ser[L-Rib(AC $\left.\left.\mathbf{A C}_{4}\right) \boldsymbol{\alpha}\right]-\mathbf{O H}\left({ }^{1} \mathrm{H}\right.$ NMR $(500 \mathrm{MHz}$, $\left.\mathrm{CDCl}_{3}\right)--\delta 7.77-7.72(\mathrm{~m}, 2 \mathrm{H}), 7.58(\mathrm{t}, J=7.6 \mathrm{~Hz}, 2 \mathrm{H}), 7.39(\mathrm{dd}, J=17.4,7.5 \mathrm{~Hz}, 2 \mathrm{H}), 7.31(\mathrm{t}, J=$ $7.4 \mathrm{~Hz}, 2 \mathrm{H}), 6.77(\mathrm{~d}, J=8.4 \mathrm{~Hz}, 1 \mathrm{H}), 5.15(\mathrm{~d}, J=2.3 \mathrm{~Hz}, 1 \mathrm{H}), 5.07(\mathrm{~s}, 1 \mathrm{H}), 4.80(\mathrm{~d}, J=2.4 \mathrm{~Hz}, 1 \mathrm{H})$, $4.59(\mathrm{~d}, J=8.5 \mathrm{~Hz}, 1 \mathrm{H}), 4.52(\mathrm{dd}, J=10.3,7.0 \mathrm{~Hz}, 1 \mathrm{H}), 4.41(\mathrm{dd}, J=10.4,6.4 \mathrm{~Hz}, 1 \mathrm{H}), 4.20(\mathrm{t}, J=$ $6.5 \mathrm{~Hz}, 1 \mathrm{H}), 4.02(\mathrm{~d}, J=8.5 \mathrm{~Hz}, 1 \mathrm{H}), 3.95(\mathrm{dd}, J=9.5,2.4 \mathrm{~Hz}, 1 \mathrm{H}), 3.87(\mathrm{~d}, J=11.6 \mathrm{~Hz}, 1 \mathrm{H})$, $3.53(\mathrm{dd}, J=12.7,3.4 \mathrm{~Hz}, 1 \mathrm{H}), 2.14(\mathrm{~s}, 3 \mathrm{H}), 2.12(\mathrm{~s}, 3 \mathrm{H}), 2.07(\mathrm{~s}, 3 \mathrm{H}) ;{ }^{13} \mathrm{C} \mathrm{NMR}\left(126 \mathrm{MHz}, \mathrm{CDCl}_{3}\right)$ -- $\delta 172.69,171.10,170.63,170.44,156.29,144.03,143.82,141.62,141.43,127.97,127.93$, $127.28,127.18,125.23,125.06,120.26,120.15,98.44,77.23,68.78,67.99,67.07,66.79,66.48$, $61.16,53.90,47.29,21.12,21.10,21.02$. 